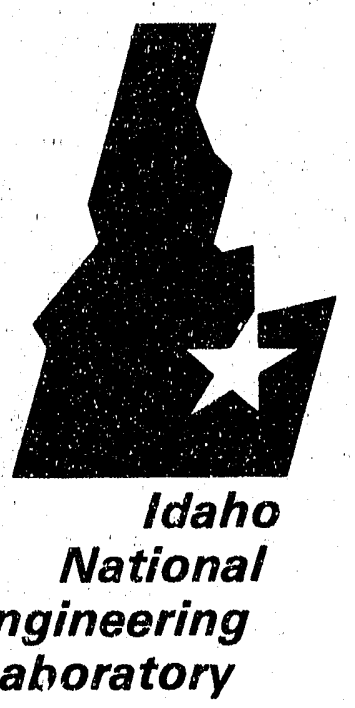

INFORMAL REPORT

EGG-WTD-9594 Vol. IV

October 1991

Preliminary Systems Design Study Assessment Report

Volume IV: Leach Resistant/High Integrity

Structure Concepts

\author{
J. L. Mayberry \\ F. Feizollahi \\ J. C. Del Signore
}

Managed

by the U.S.

Department

of Energy

$$
\text { MAR } 2 \text { G } 1902
$$

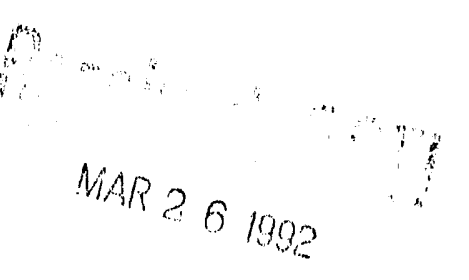


EGG-WTD--9594-Vol. 4

DE92 010848

\title{
PRELIMINARY SYSTEMS DESIGN STUDY ASSESSMENT REPORT
}

\author{
VOLUME IV \\ LEACH RESISTANT/HIGH INTEGRITY STRUCTURE \\ CONCEPTS
}

J. L. Mayberry

F. Feizollahi

J. C. Del Signore

Published October 1991
liaho National Engineering Laboratory
EG\&G Idaho, Inc.
Idaho Falls, Idaho 83415

\author{
Prepared for the \\ U.S. Department of Energy \\ Office of Environmental Restoration and Waste Management \\ Under DOE Field office, Idaho \\ Contract DE-AC07-76ID01570




\section{PRELIMINARY SYSTEMS DESIGN STUDY \\ ASSESSMENT REPORT \\ EGG-WTD-9594 \\ Volume IV}

Prepared by:

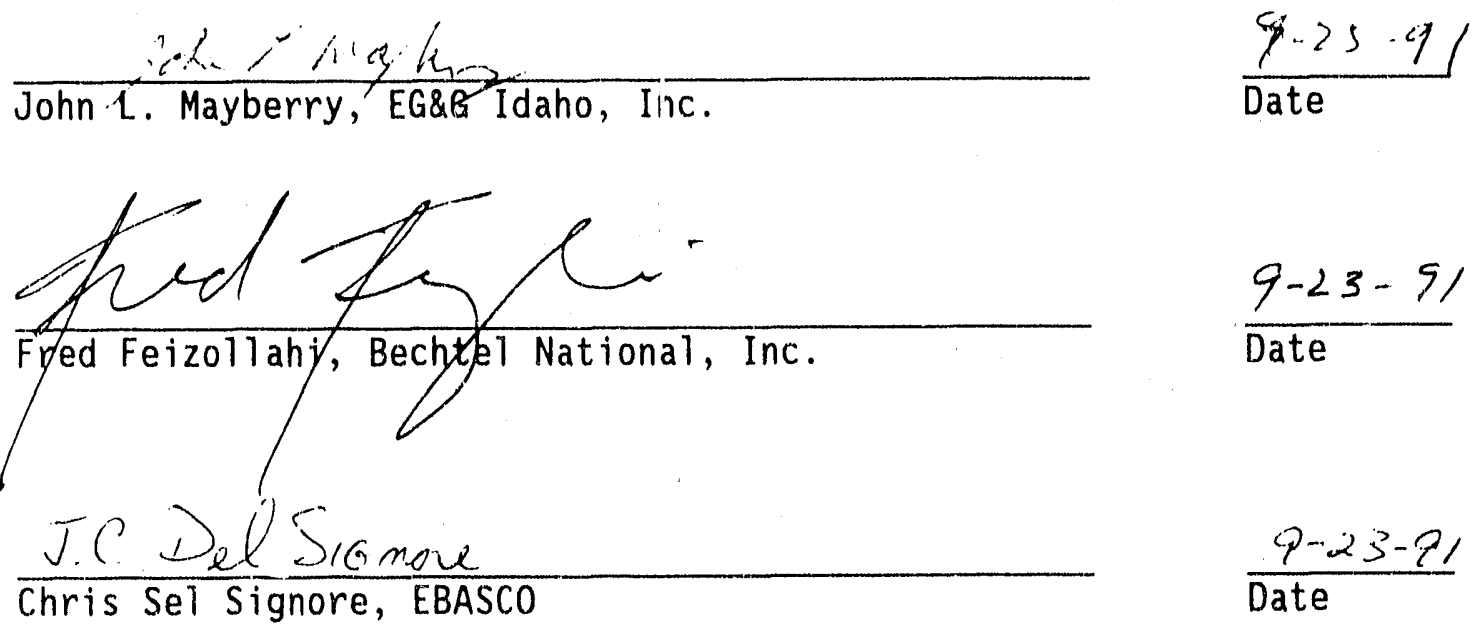

Reviewed and Approved by:

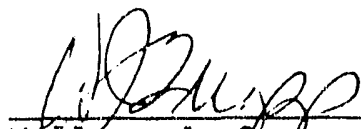

Wi]l tam J. Chafpp, Manager Technology Demonstration, Haste Technology Development Dept.

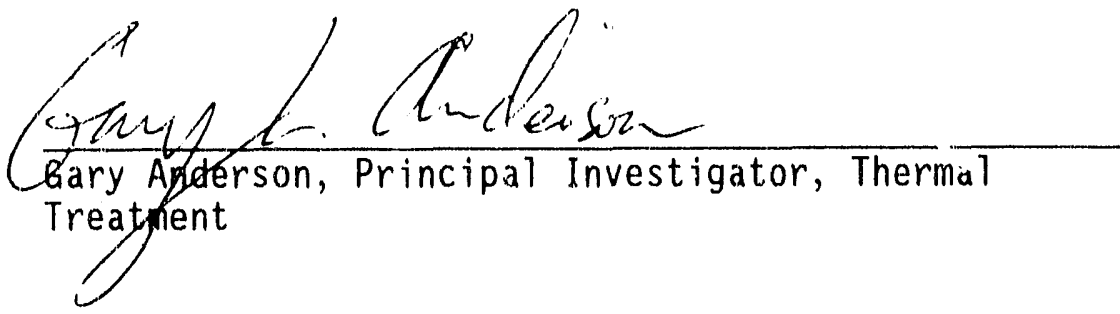

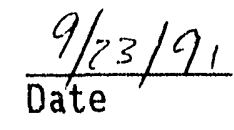

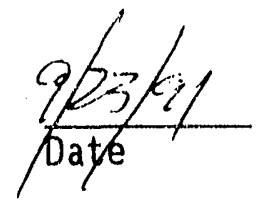




\begin{abstract}
The System Design Study (SDS), part of the Waste Technology Development Department at the Idaho National Engineering Laboratory (INEL), examined techniques available for the remediation of hazardous and transuranic waste stored at the Radioactive Waste Management Complex's Subsurface Disposal Area at the INEL. Using specific technologies, system concepts for treating the buried waste and the surrounding contaminated soil were evaluated. Evaluation included implementability, effectiveness, and cost. The SDS resulted in the development of technology requirements including demonstration, testing, and evaluation activities needed for implementing each concept.
\end{abstract}

The SDS results are published in eight volumes. Volume I contains an executive summary. The SDS summary and analysis of results are presented in Volume II. Volumes III through VII contain detailed descriptions of twelve system and four subsystem concepts. Volume VIII contains the appendixes.

\title{
DISCLAIMER
}

This report was prepared as an account of work sponsored by an agency of the United States Government. Neither the United States Government nor any agency thereof, nor any of their employees, makes any warranty, express or implied, or assumes any legal liability or responsibility for the accuracy, completeness, or usefulness of any information, apparatus, product, or process disclosed, or represents that its use would not infringe privately owned rights. Reference herein to any specific commercial product, process, or service by trade name, trademark, manufacturer, or otherwise does not necessarily constitute or imply its endorsement, recom. mendation, or favoring by the United States Government or any agency thereof. The views and opinions of authors expressed herein do not necessarily state or reflect those of the United States Government or any agency thereof. 


\section{ACKNOWLECGMENTS}

The authors would 1 ike to acknowledge the efforts of those that contributed to this report.

EG\&G Idaho, Inc., Bechtel National, Inc., Ebasco Environmental, and IT corp. for providing the assessments and functional and operational requirements for the 12 system and 4 subsystem concepts. Specifically, C. Klassy, K. Sherick and D. Haifner of EG\&G Idaho, Inc., R. Schlueter, M. Pong, D. Harris, M. Beathard and P. Yen of Bechtel National, Inc., D. Prinzing, J. Bjorkstam, R. Vankateswar and S. Peck of Ebasco Environmental, J. Plum, J. Valdez, D. Vetter, M. Chavez, S. Djordevic, M. Swientoniewski, John McFee of IT Corp., and H. Kresny of Solmont Corporation.

Karen Grant and Janalee Nelson of EG\&G Idaho, and Debra Iniquez of Bechtel National, Inc., for the extra effort required in editing this report. 


\section{CONTENTS}

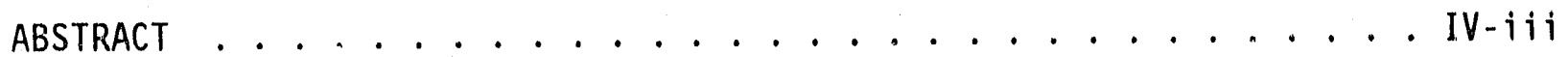

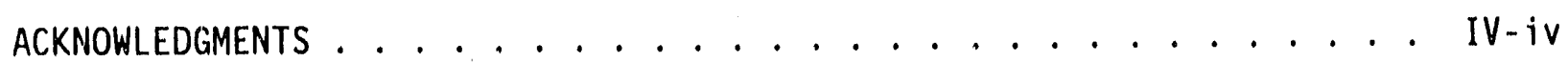

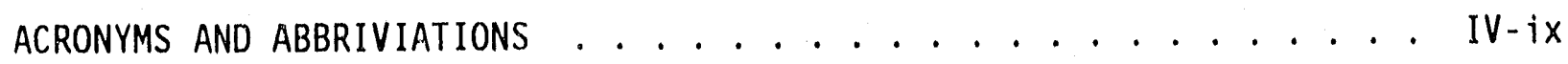

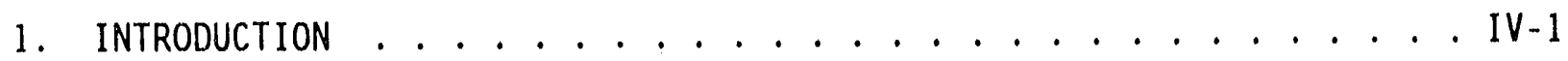

1.1 Background . . . . . . . . . . . . . . IV-1

1.2 Organization of the System Design Study Report . . . . . . IV-2

1.3 Content and Organization of this Volume ......... IV-2

1.4 System Concept Limitations . . . . . . . . . . . IV-3

1.5 General Considerations and Assumptions Used in System Concepts

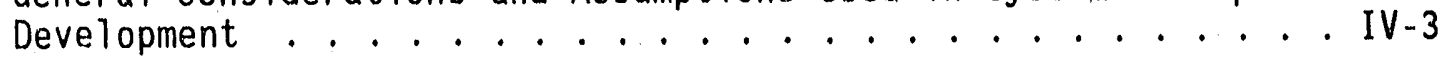

1.5.1 Waste Property Assumptions ............. IV-3

1.5.2 General Assumptions ............. IV-5

1.6 Criteria and Assumptions for Program Implementation Risk
Assessment . . . IV-6

1.6.1 Project Mission Need and Objectives ........ IV-6

1.6.2 Technical and Performance Risk Considerations . . . . . IV-7

1.6.3 Health and Safety Risk Considerations . . . . . . . IV-8

1.6.4 Institutiona! Risk Considerations . . . . . . . . . IV-10

1.6.5 Schedule Risk Considerations ........... IV-11

1.6.6 Cost Risk Considerations . . . . . . . . . IV-11

1.7 Cost Estimating Assumptions . . . . . . . . . IV-11

1.7.1 Cost Estimating Guidelines . . . . . . . . IV-11

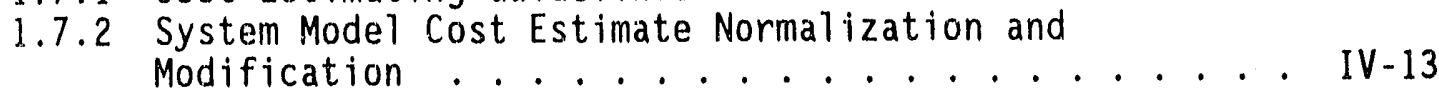

1.8 Demonstration, Testing, and Evaluation Assessment
Assumptions....................... IV-14

2. MELTING AND INCINERATION SYSTEM WITH LLW PRESORT (2-EG-1) . . . IV-21

2.1 Functional and Operational Requirements ......... IV-21

2.1 .1 System Description .............. IV-21

2.1 .2 System Boundaries . . . . . . . . . . . IV-23

2.1 .3 Process runctional Diagram ........... IV-23 
2.1.4 Facility Description .............. . IV-30

2.1.5 System Design Requirements . . . . . . . . . . IV-32

2.1.6 Interface Requirements ............. . IV-32

2.2 System Assessment . . . . . . . . . . . . . . IV -33

2.2.1 Current Status of Unit Operations........... IV-34

2.2.2 Program Implementation Risks ............. . IV-49

2.2.3 Unit Operations Pro and Con Analys is . . . . . . . IV-56

2.2.4 Unit Operations Lead-Time Estimates . . . . . . . . IV-60

2.2.5 Rough Order of Magnitude Cost Estimates........ . IV-60

2.2.6 System Evaluation Results.............. IV-63

2.2.7 Summary of Demonstration, Testing, and Evaluation
Needs.............................. IV

2.3 Recommendation for the System .............. IV-64

3. MELTING AND INCINERATION SYSTEM WITH LLW POSTSORT (2-EG-4) • . . . IV-67

3.1 Functional and Operational Requirements . . . . . . . . . IV-67

3.2 System Assessment . . . . . . . . . . . . . . . . . IV-73

4. IN SITU VITRIFICATION AND RETRIEVAL PROCESSING SYSTEM (2-EB-3) • . IV-77

4.1 Functional and Operational Requirements . . . . . . . . . IV-77

4.1.1 System Description ................ IV -77

4.1.2 System Boundaries................. . IV-80

4.1.3 Process Functional Diagram ............ IV 83

4.1.4 Facility Description ............. . IV-83

4.1.5 System Design Requirements . . . . . . . . . . . IV -87

4.1.6 Interface Requirements ................ IV-91

4.2 System Assessment . . . . . . . . . . . . . . . . IV -95

4.2.1 Current Status of Unit Operations . . . . . . . . . IV-95

4.2.2 Program Implementation Risks............ . IV-99

4.2.3 Unit Operations Pro and Con Analys is . . . . . . . . IV-106

4.2.4 Unit Operations Lead-Time Estimates . . . . . . . . . . IV-108

4.2.5 Rough Order Magnitude Cost Estimates . . . . . . . . . IV-110

4.2.6 System Evaluation Results .............. IV-113

4.2.7 Summary of Demonstration, Testing, and Evaluation
Needs........................... IV-115

4.3 Recommendation for the System . . . . . . . . . . . IV-116

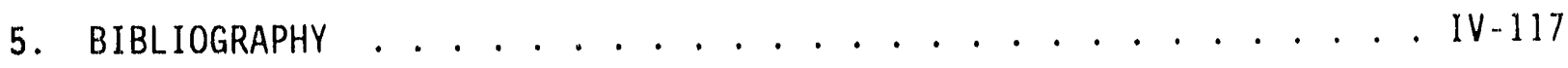




\section{FIGURES}

IV-1-1. Categories of work effort and research and development or acquisition phases................. IV-16

IV-1-2. Breakdown of demonstration, testing, and evaluation activities during advanced development .......... . IV-18

IV-2-1. Process functional diagram for the Melting and Incineration System with LLW Presort (2-EG-1)............. IV-22

IV-2-2. Layout of the processing facility for the Melting and Incineration System with LLW Presort (2-EG-1) ........ IV-31

IV-3-1. Process functional diagram for the Melting and Incineration System with LLW Postsort (2-EB-4) ........... . IV-68

IV-3-2. Layout of the processing facility for the Melting and Incineration System with LLW Postsort (2-EB-4)....... . IV-72

IV-4-1. Process functional diagram for the In Situ Vitrification and Retrieval Processing System (2-EB-3)........... . IV-84

IV-4-2. Secondary containment for the eight operating ISV off-gas collection hoods................... IV-85

IV-4-3. ISV secondary enclosure section . . . . . . . . . . . IV-86

IV-4-4. Thermal treatment facility............... . IV-88

\section{TABLES}

IV-2-1. Mass and volume of waste by category . . . . . . . . IV-27

IV-2-2. Assumed composition of buried waste combustibles . . . . . . IV-29

IV-2-3. Unit operation estimated capabilities . . . . . . . . . IV-30

IV-2-4. DT\&E needs for the Melting and Incineration System with LLW Presort (2-EG-1)................. IV-35

IV-2-5. 2-EG-1 summary of program implementation risks and major areas of concern.................. IV-50

IV-2-6. DT\&E lead-time estimate for the Melting and Incineration

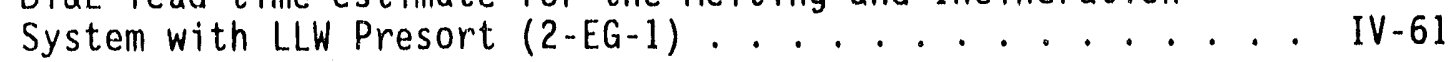

IV-2-7. Rough order of magnitude cost estimates (2-EG-1) . . . . . IV-62 
IV-2-8. Rating measurables for the Melting and Incineration System with LLW Presort $(2-E G-1)$. . . . . . . . . . . . IV-65

IV-3-1. Mass and volume of waste by category. . . . . . . . . IV-70

IV-3-2."Unit estimated capabilities . . . . . . . . . . . IV-71

IV-3-3. 2-EG-4 summary of program implementation risks and major areas of concern................ IV 74

IV-3-4. Fiough order of magnitude cost estimates (2-EG-4) . . . . . IV-76

IV-4-1. 2-EB-3 summary of program implementation risks and major areas of concern.................. IV-100

IV-4-2. DT\&E lead-time estimates for the In Situ Vitrification and Retrieval Processing System (2-EB-3)........... IV-109

IV-4-3. Rough order of magnitude cost estimates (2-EB-3) . . . . . IV-111 IV-4-4. Rating performance measurables for the In Situ Vitrification and Retrieval Processing System (2-EB-3). . . IV-115 


\section{ACRONYMS AND ABBRIVIATIONS}

AEC

ALARA

ANL - W

ARAR

CAA

CCD

CDIF

CEA

CEPOD

CEQ

CERCLA

CFR

CM

CWA

DOD

DOE

DOE - ID

DOT

dscf

DT\&E

EG\&G Idaho

EM

EOF

EPA
U.S. Atomic Energy Commission

as low as reasonably achievable

Argonne National Laboratory-West

applicable or relevant and appropriate requirement

Clean Air Act

charged coupled device

Component Development Integration Facility

Atomic Energy Commission (France)

catalytic electrolytic plutonium oxide dissolution

Council of Environmental Quality

Comprehensive Exy ironmental Response, Compensation, and Liability Act

Code of Federal Regulations

construction management

Clean Water Act

U.S. Department of Defense

U.S. Department of Energy

Department of Energy-Field Office, Idaho

U.S. Department of Transportation

dry standard cubic feet

demonstration, testing, and evaluation

EG\&G idaho, Inc.

electromagnetics

energy optimizing furnace

U.S. Environmental Protection Agency 
ER

ERDA

ERP

F\&OR

FFBD

FOM

FS

FY

GPR

HAZMAT

HEPA

HVAC

IAG

INEL

$\mathrm{I} / 0$

ISV

I.ANL

LDR

L.LNL

LLW

MAF

MF

MSA

MSO

MSW

NEPA environmental restoration

Energy Research and Development Admintstration

Environmental Restoration Program

functional and operational requirement

functional flow block diagram

Figure of Merit

feasibility study

fiscal year

ground penetrating radar

hazardous material

high-efficiency particulate air (filter)

heating, ventilating, and air conditioning

Interagency Agreement

Idaho National Engineering Laboratory

input/output

in situ vitrification

Los Alamos National Laboratory

land disposal restriction

Lawrence Livermore National Laboratory

low-level waste

moisture and ash-free fraction

melting furnace

Major System Acquisition

Molten Salt Oxidation

municipal solid waste

National Environmental Policy Act of 1969 


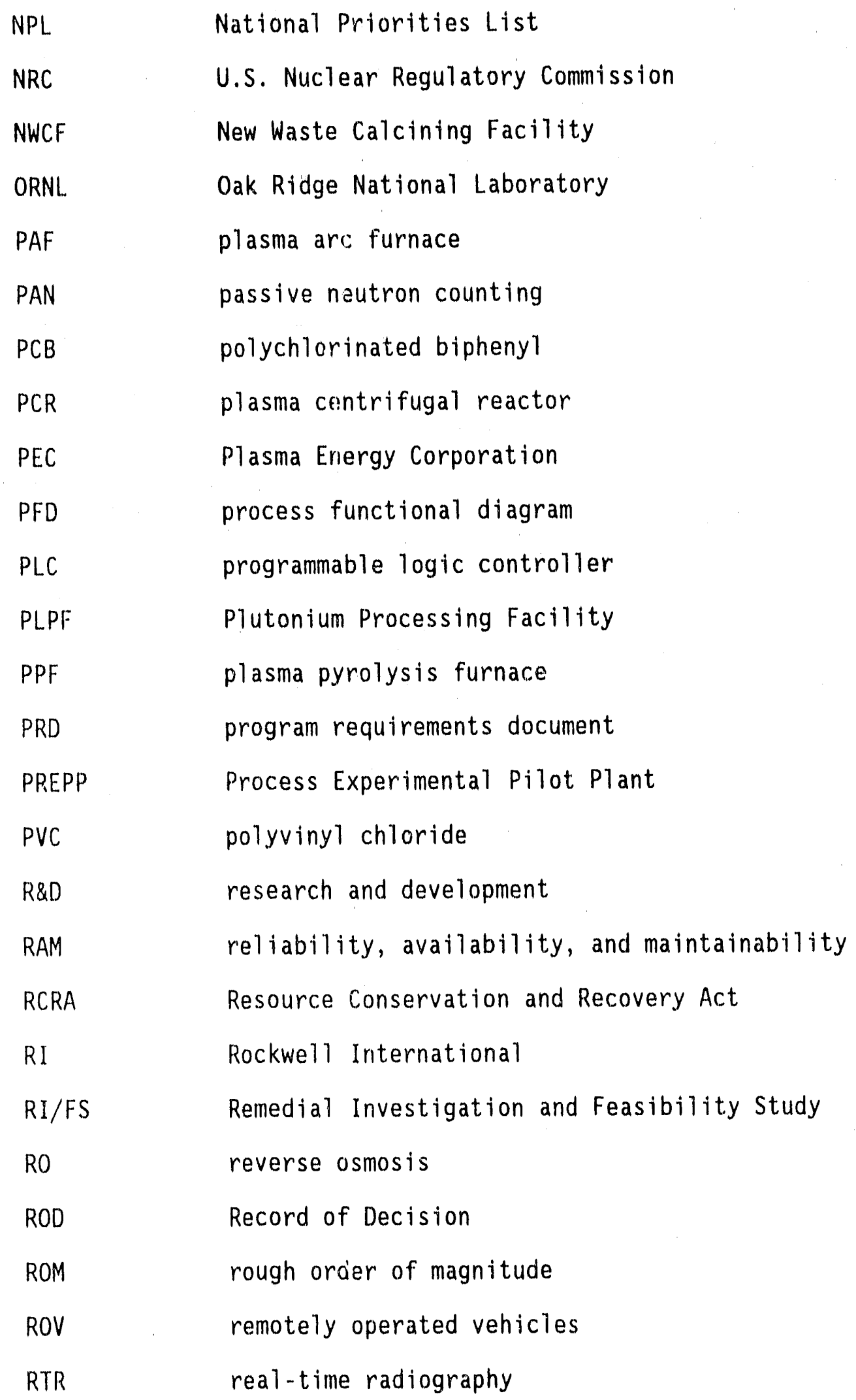




\begin{tabular}{|c|c|}
\hline RWMC & Radioactive Waste Management Complex \\
\hline SAIC & Science Applications International Corporation \\
\hline scfm & standard $\mathrm{ft}^{3} / \mathrm{min}$ \\
\hline$S D A$ & Subsurface Disposal Area \\
\hline SDS & System Design Study \\
\hline SDWA & Safe Drinking Water Act \\
\hline SEG & Scientific Ecology Group \\
\hline SGS & gamma spectroscopy \\
\hline SWEPF & Stored Waste Examination Pilot Plant \\
\hline TCLP & toxicity characteristic leaching procedure \\
\hline TEC & total estimated cost \\
\hline$T / 0$ & tradeoff \\
\hline TRAMPAC & transportation package \\
\hline TRU & transuranic \\
\hline TSA & Transuranic Storage Area \\
\hline TSCA & Toxic Substances Control Act \\
\hline TVR-III & Transportable Volume Reduction and Solidification System \\
\hline UCRL & University of California Research Laboratories \\
\hline$U / R$ & utilization of resources \\
\hline VOC & volatile organic compound \\
\hline WAC & waste acceptance critaria \\
\hline WAG & Waste Area Group \\
\hline WERF & Waste Experimental Reduction Facility \\
\hline WIPP & Waste Isolation Pilot Plant \\
\hline
\end{tabular}




\section{VOLUME IV \\ LEACH RESISTANT HIGH INTEGRITY STRUCTURE CONCEPTS}

\section{INTRODUCTION}

\subsection{BACKGROUND}

Remediating the Idaho National Engineering Laboratory (INEL) transuranic (TRU) buried warte at the Subsurface Disposal Area (SDA) will require a complex set of technologies for safe treatment and disposal of the waste. A key question for achieving the Buried Waste Program objectives is which practical and cost effective technologies could be used as candidates to satisfy the objectives of this program. To provide an answer to this question, a system design study (SDS) was commissioned based on system engineering principles advocated by the U.S. Department of Energy (DOE) Order 4700.1. The SDS examined the existing and emerging technologies for cost-effective remediation of the buried waste. Since no one technology can accommodate the complex remedial action process, several technologies were corisidered as a system. While examining the technology options, the SDS focused on the technology requirements aspect of the systems engineering. The intent was to identify a set of cost-effective, practicai, acceptable treatment strategies; develop system concepts encompassing these strategies; and identify technologies within these concepts that will require demonstration, testing, and evaluation (DT\&E).

In addition to developing technology requirements, the SDS concepts were developed so they can be used in future studies for establishing other detailed (derived) system requirements such as input/output (I/0) requirements and utilization of resource (U/R) requirements. 


\subsection{Drganization of the System Design Study Report}

The SDS results are published in eight volumes. Volume I contains an executive summary. The SDS summary and analysis of the results are presented in Volume II. Volumes III througr, VII contain a detailed description and assessment of twelve system and four subsystem concepts. Volume VIII also includes appendices.

\subsection{Content and Organization of this Volume.}

This volume contains an introduction section containing a brief SDS background and lists the general assumptions and considerations used during the development of the system concepts. The introduction section is followed by sections describing three system concepts that produce a stabilized and confined waste form achieved by in-place treatment techniques. This system concept category is referred to as Waste Form 2, "Leach Resistant High Integrity Structure." The following three system concepts are under this category:

- Melting and Incineration with Low-Level Waste (LLW) Presort (2-EG-1)

- Melting and Incineration with LLW Postsorting System (2-EG-4)

- In Situ Vitrification (ISV) and Retrieval Processing System (2-EB-3).

Each concept is developed through functional allocation and analysis up to a point that major unit operations are identified. For each concept, first a system description is presented. The system description section describes the overall system and its functional and operational requirements, boundaries, process functional diagram, facility, and design and interface requirements. This section is followed by a system assessment section consisting of the current status of unit operations, system implementation 
risks, unit operations pro and con analyses, unit operations lead time estimates, and rough order of magnitude (ROM) cost estimates. Also included i. a summary of the system evaluation results.

\subsection{Systam Concept Limitations}

The system concepts aeveloped for the SDS are of a preliminary nature. System assessments are qualitative and are based on the judgment of the SDS team members assigned to develop the given system model. It is believed that the current level of detail is adequate to provide input to develop the Buried Waste Program initial technology requirements and provide a vision for the DT\&E planning process. More detailed development of these models will be needed to support the concept exploration, evaluation, and recommendation phase of the Buried Waste Program.

\subsection{General Constderations and Assumptions Used in System CONCEPTS DEVELOPMENT}

\subsubsection{Waste Property Assumptions}

The waste input considered in this study are described in a document titled A Brief Analysis and Description of Transuranic Wastes in the Subsurface Disposal Area of the Radioactive Waste Management Complex at the INEL. (see Volume VIII, Appendix A) (Arrenholz and Knight, 1991). The following are additional assumptions concerning the input waste criteria:

- The total volume of waste is $2,325,000 \mathrm{ft}^{3}$; the total volume of contaminated soil is $9,734,000 \mathrm{ft}^{3}$. The average density of the waste is $37.23 \mathrm{lb} / \mathrm{ft}^{3}$. The average density of the soil is $116 \mathrm{lb} / \mathrm{ft}^{3}$.

- Forty percent of the actual waste is low-level waste (LLW) (i.e., less than $100 \mathrm{nCi} / \mathrm{g})$. 
- Ninety percent of the soil is LLW or clean. Soils contain both organic and inorganic hazardous components.

- Al1 lead wastes are or can be made into LLW. Assume that lead is one percent of the waste by weight.

- Waste containing materials that can jeopardize the safety of retrieval and processing operations either exist in small quantities and can be safely handled, or can be segregated out for handling and processing as special material (see below). Examples of waste material in this category are high radiation objects, containers having free liquids, and compressed gas cylinders.

- The removal and treatment of the rock sub-layer are not included in this system analysis.

- Terms used to characterize certain waste types are as follows:

Special material-includes waste that is not suitable for normal processing (i.e., processing capability of the system concept described in this report) including large objects, high radiation materials, large construction material, and any object requiring special hardling and processing not included in the system design. Processing and handling features for special material are not included in the system models. Special material handling, processing, and disposal metrods will be decided on a case by case basis.

- Large objects--include discarded vehicles, reactor shielding, tanks, etc.

- Large construction material--includes discarded construction material such as concrete slabs, stael beams, sections of brick walls, timber, etc. 
- High radiation objects--include reactor vessels, piping, pumps, fuel components, etc.

\subsubsection{General Assumptions}

The following general assumptions are used in developing the systems concepts:

- Any plutonium recovery is strictly for TRU reduction, not recycling.

- All TRU waste metals will be decontaminated for volume reduction.

- The bulk of the soil can be excavated without waste being entrained. A small amount of soil is contaminated by the waste.

- The retrieval will be done inside a building that is classified as a low hazard facility per University of California Research Laboratories (UCRL) 15910.

- The processing buildings for LLW and TRU are classified as a Solid Radioactive Waste Facility per DOE Order 6430.1A and a moderate hazard facility per UCRL 15910.

- The operational time span required for the production-scale processing of the plutonium-contaminated waste is 10 years.

- Operational assumptions:

\footnotetext{
$-24 \mathrm{~h} / \mathrm{d}$

- $\quad 5 \mathrm{~d} / \mathrm{wk}$

- $\quad 70 \%$ plant availability during operation

- Operational $240 \mathrm{~d} / \mathrm{yr}$.
} 


\subsection{Criteria and Assumptions for Program Implementation RISK ASSESSMENT}

For each of the system concepts, the programmatic risks associated with implementing the system model have been assessed. This risk assessment has attempted to identify the major uncertainties requiring further focused work and attention. An estimate is provided of the confidence level to meet the objectives stated in Volume II. The risk assessment was performed according to the guidelines given in DOE Order 4700.1 for risk assessment during the "initial project planning phase." Program implementation risk assessments in this report are qualitative and are based on the judgement of the study team members. Because the buried waste remedial action program is still in the early phase of the systems development/acquisition process, information for a more detailed risk analysis does not yet exist. Hence, thie qualitative judgments are based on several assumptions, which are presented below.

Each of the systems unit operations was considered during this initial risk assessment of the system concepts. A composite risk level for the overall system concept was assigned based on the risk associated with the unit operations. In most cases, only the overall system risks are presented in this report. In general, a low risk ranking implies that the system could be implemented now with virtually no risk. Assignment of moderate rank means that although the implementation of the system concept is presently feasible, certain aspects of implementation still need to be resolved. If a system concept has a considerable amount of uncertainty regarding achievement of the given objective, then a high risk ranking is assigned.

\subsubsection{Project Mission Need and Objectives}

The project mission need and objectives are given in Volume II. A summary of the objectives is presented below:

- Performance objectives: Baseline cleanup standards for buried waste sites at the Radioactive Waste Management Complex (RWMC) cannot be officially established until a Record of Decision (ROD) 
pursuant to the Comprehensive Environmental Response, Compensation, and Liability Act (CERCLA) process is reached for the Remedial Action. These standards will be derived through (a) the Applicable or Relevant and Appropriate Requirement (ARAR) process under CERCLA, (b) standards set by risk assessments, and (c) the State and local requirements.

- Health and safety: Key health and safety objectives are to (a) identify the hazards of the remedial action operation, and (b) provide measures to eliminate, control, or mitigate identified hazards.

- Institutional objectives: Key institutional objectives are to involve the state agencies and the public in the process of selecting a remedial action for the buried waste and ensure compliance with the National Environmental Policy Act of 1969 (NEPA) and CERCLA public participation requirements.

- Schedule objectives: The objective schedule is to reach approval for Title II start by fiscal year FY 1999. This is based on the assumptions that an ROD under CERCLA will be reached by the end of FY 2001. The schedule objective is to complete the Buried Waste Program by FY 2019.

- Cost objective: At this time, the cost objective for the Buried Waste Program is cost-effectiveness. A baseline budget including cleanup costs has not yet been established.

\subsubsection{Technical and Performance Risk Considerations}

The following considerations were used in characterizing the technical performance risks:

- Contamination type and size: The TRU waste buried at RWMC has been characterized for this study (see Volume VIII, Appendix A). 
Based on these waste characteristics, the risks are characterized relative to the ability to comply with the performance objectives. However, it should be noted that detailed and accurate information on the materials buried at each of the trenches and pits or the extent of the site contaminants does not exist at this time. If found, pyrophoric materials and compressed gas cylinders containing volatile and toxic gases can have a significant impact on the performance compliance risk characterization.

- Major ARARs for in situ treatment options: Major ARARs for in situ options are Resource Conservation and Recovery Act (RCRA), DOE, and U.S. Nuclear Regulatory Commission (NRC) regulations and guidelines for disposal of waste in shallow land burial sites [10 Code of Federal Regulation (CFR) 61].

- ARARs for thermal processes: Major ARARs for thermal processes are the Clean Air Act, and RCRA and DOE regulations for radiation protection.

\subsubsection{Health and Safety Risk Considerations}

The following considerations were used to characterize the health and safety risks:

- General construction-related concerns: As with any constructionrelated activity, there will be general health and safety concerns associated with the buried waste cleanup operations. Risk associated with the ability of the program to jefine and mitigate general construction related to health and safety concerns is believed to be low.

- Radioactive and hazardous material handling concerns: Because of radioactive (including TRU), hazardous, mixed waste contamination of the material that will be encountered during operations, the program will be subject to health and safety concerns with respect 
to low-level radiation, TRU contamination, and hazardous material exposures. The risk assoctated with the ability of the program to define and mitigate these health and safety concerns is believed to be moderate for all systems options involving retrieval and processing, and low for all options involving in situ treatment.

- Criticality: Because of the measurable quantity of plutonium in the buried waste, the program will be subject to riealth and safety concerns with respect to criticality. The risk associated with the ability of the program to define and mitigate these health and safety concerns is largely dependent on the avallability of techniques to detect Pu contamination in the waste before it is handled. In this study, it is assumed that such techniques are available for all system models, except those using the ISV process; therefore, the assigned risk is low.

For the ISV process, the concern is that the melting of the material may result in potential concentration of $\mathrm{Pu}$ in the bottom of the melt. To mitigate this potential safety concern, a nonintrusive assay technique to determine Pu concentration in the buried waste would be needed. Such a technique is beyond the realm of the existing ipchnology. A preliminary review of criticality in the ISV process, however, suggests that because of the high chemical reactivity of molten $\mathrm{Pu}$ metal and the high melting point and moderate specific gravity of compounds ( $\mathrm{PuO}_{2}$, $\mathrm{PuCL}_{3}$, $\mathrm{PuH}_{4}$, etc.) that would most likely form, the risk of Pu collecting in a quantity and geometry that would allow a critical mass to form is very low. Because of the consequences of such an occurrence, however, the subject should be examined in more depth during the site characterization effort. For this study, the risk to identify and mitigate criticality concerns for the ISV options is considered to be low.

- Pyrophoric and volatile and toxic gas: Since the SDS waste characteristics document (see Volume VIII, Appendix A) does not 
identify pyrophoric matertal or compressed gas cylinders containing volatile and toxic gases, the abllity of the program to define and mitigate health and safety concerns related to these wastes are not addressed at this time.

\subsubsection{Institutional Risk Considerations}

The following considerations were used in characterizing the risks:

- Disposing residues after retrieval: Options irivolving ex situ treatments (i.e., excavation, removal, and disposal) will involve disposal of TRIJ-contaminated mixed waste. Currently, DOE has no disposal space for these wastes. Therefore, the question of institutional risk of ex situ techniques will require addressing ultimate disposal of the residues. However, since the system boundary for the SDS does not include the ultimate disposal of the residues, characterization of the institutional risk did not address the disposal question.

- State and public acceptance of leave-in-place options: System leave-in-place options are characterized as a high risk with regard to institutional acceptance. This is due to anticipated opposition by the state and the public. Over the last several years, the State of Idaho and the Federal Government have communicated several times concerning the retrieval and removal of TRU waste buried at the INEL. DOE and its predecessors, the U.S. Atomic Energy Commission (AEC) and the Energy Research and Development Administration (ERDA), have made commitments to the State of Idaho to remove the TRU waste.

- Thermal process public acceptabllity: Because of past experience in public opposition at other DOE sites (e.g., Rocky Flats), system options involving the incineration process are characterized as a high risk with regard to acceptance. 


\subsubsection{Schedule Risk Considerations}

The following considerations were used to characterize the risks:

- Time avallable for DT\&E: As indicated above, the schedule ubjective is to reach Title II design by FY 1999. To achieve this objective, it is assumed that detalled information to evaluate the remedial action options is needed by 1996. Therefore, any system concept requiring DT\&E lead-time longer than five years is belleved to be a high risk.

- Thermal system burn test requirements: Because of past experience in lengthy burn tests and the U.S. Environmental Pratection Agency (EPA) approval process at other DOE sites (e.g., Rocky Flats and Oak Ridge National Laboratories), system options involving incineration processes are characterized as a moderate risk in regard to compliance with the schedule objectives.

\subsubsection{Cost Risk Considerations}

Since a baseline cost estimate has not been established at this time, the assessment of cost risk is based on how well the program will be able to define the cost of the given system in the future if the system is selected as the preferred option. As indicated in Section 1.6.2, pyrophorics and compressed gas cylinders containing volatile and toxic gases can have a significant impact on the technical performance risk characterization if fourd. This will also impact cost risk characterization.

\subsection{Cost Estimating Assumptions}

\subsubsection{Cost Estimating Guidelines}

Cost estimating guidelines were developed to support development of an ROM cost for each system concept. The guidelines included building/space cost 
per square foot, and design, inspection, and project administration percentages for the vartous types of butlding/space. Also included are operating costs to be considered for development of $11 \mathrm{fe}$ cycle costs. Al1 costs are presented in FY 1991 dollars, including operating and maintenance costs.

1.7.1.1 Butlding Space costs. The bullding unit rate costs 1 isted below are based on similar factlities at the INEL. The costs are representative of the butlding and its support systems, including utilities and site development costs. The Alpha Cell Space butlding costs include the high-efficiency particulate air (HEPA) filter systems. Special equipment and any additional mechanical or electrical systems needed for the operation of the equipment has not been included in these costs. The unit rates include direct and indirect construction costs. Indirect costs associated with the additional building costs and equipment costs are established to be 20.5 percent of the direct costs.

- High hazard building space $\$ 650 / \mathrm{ft}^{2}$

- Moderate hazard building space $\$ 350 / \mathrm{ft}^{2}$

- Alpha cell space with one confinement barrier $\$ 1000 / \mathrm{ft}^{2}$

- Alpha cell space with two confinement barriers $\$ 1200 / \mathrm{ft}^{2}$

- Retrieval building space $\$ 100 / \mathrm{ft}^{2}$

1.7.1.2 Design Inspection and Project Administration Costs. To determine the design, inspection, and project administration costs for each option, the percentages listed below were applied. These percentages are historical averages for types of activities covered by SDS concepts. 
- Contingency on all costs 25\%

- Design costs applied to construction costs (both $30 \%$ demonstration and production)

- Inspection costs applied to construction costs $7 \%$ (both demonstration and production)

- Project administration applied to construction $10 \%$ costs (both demonstration and production)

- Indirect costs applied to total construction costs $20.9 \%$ (both demonstration and production)

- Construction management (CM) and $C M$ reserve (combined percent) applied only to production construction cost

1.7.1.3 Operating Costs. The utility rates and operating rates 1 isted below were established by EG\&G Idaho, Inc. (EG\&G Idaho) for use in the developinent of life cycle costs. Present day costs were used for the preparation of these estimates. A contingency factor of $25 \%$ was applied to the project subtotal.

\begin{tabular}{|c|c|c|}
\hline & Electricity & $\$ 0.035 / \mathrm{kWh}$ \\
\hline & Propane & $\$ 0.60 / \mathrm{gal}$ \\
\hline 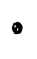 & Operating staff & $\$ 60 / h$ \\
\hline
\end{tabular}

\subsubsection{System Model Cost Estimate Normalization and Modification}

ROM cost estimates were prepared by the team members for the 12 systems and 4 subsystems based on the above guidelines. These initial cost estimates were examined by an independent estimating team to determine if the estimates were comparable in estimating approach and techniques. If not, the estimate approach and techniques were modified so that the estimates could be compared to one another. The independent estimating team corrected the initial estimate inconsistencies concerning the appication of multipliers, estimating approach, summary sheets, backup sheets, years of operation, and cost per square foot. The following steps were used to modify the estimates: 
- Normalized costs: The initial ROM estimates for the 12 systems and 4 subsystems were first "normalized" by a consistent application of the multipliers for indirect, design, inspection, project administration, construction managament, and contingency. These revised ROM cost estimates were referred to as normalized ROM costs.

- Modified costs: A second review of the 12 system and 4 subsystem model ROM cost estimates was conducted for comparable square footage in allocating the building space, consistent cost per square foot, consistent time basis used in operating and maintenance costs, omissions and errors, and comparable equipment costs with other similar equipment used within the 16 estimates. The ROM cost estimates of the 12 system models were revised to correct any of the above inconsistencies. These estimates were called modified costs. The following modifications were made:

- Because of inconsistent use of criteria, the system models facility sizes were corrected to remove front end receiving, unloading and storage areas, and back end drum storage areas. Space requirements for these functions were assumed to be $200,000 \mathrm{ft}^{2}$ for a11 ex situ system models. The ROM cost for this space was estimated to be approximately $\$ 30$ million.

- An average square footage for similar operations was developed and used in cases where assignment of alpha cell square footage varied widely for similar operations.

\subsection{Demonstration, Testing, and Evaluation Assessment AsSUMPTIONS}

Major unit operations in each of the system and subsystem models were evaluated to estimate DT\&E needs, lead-time, and resource requirements. Some of the criteria and assumptions used as the basis for these estimates follow: 
Project execution: It is assumed that the Buried Waste Program will be executed according to the project management system advocated by DOE Order 4700.1. Figure IV-1-1 shows the various categories of vork and the various phases of the research and development in a typical project executed under the DOE order 4700.1 requirements.

- Research and development (R\&D) categories of technologies: It is intended that the 12 system and 4 subsystem options considered in the SDS do not use technologies that fall in the categories of "basic research," "applied research," or "technoloyy or exploration development" as defined in DOE Order 4700.1 (page 1-5). Only technologies that have passed the "technology or exploration development" stage are assessed. Under the EG\&G Idaho Research Development DT\&E Program definitions, technologies considered are assumed to

Have completed R\&D activities to apply knowledge from research toward proof of technology including development of non-specific application prototypes and processes

Require only DT\&E activities to

- Compare the effectiveness of alternative processes

-- Determine the applicability of a particular technology to a site-specific use

- Establish a level of confidence in a treatment process

- Yield such information as process results, design criteria, and operational sensitivities

- Obtain regulatory agency concurrence or approvals, as needed. 


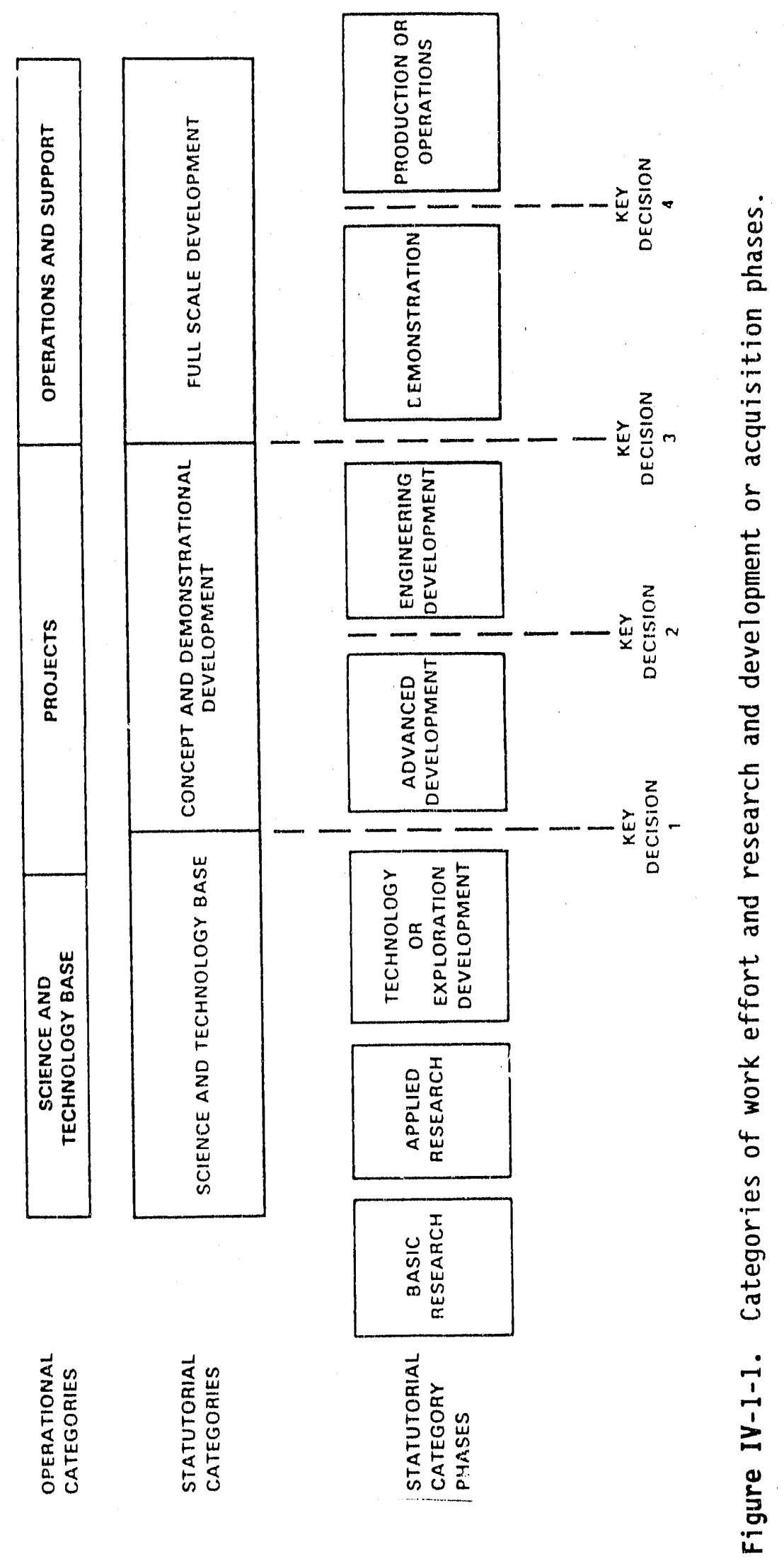


The EG\&G Idaho DT\&E activities are considered to be comparable to the "advanced development" activities defined in DOE Order 4700.1.

- DT\&E output assumptions: When a DT\&E program is proposed for a given unit operation, the intent is to develop the unit operation to a point where the results will support DOE key decision 2 for the Buried Waste Program. As defined in DOE Order 4700.1, key decision 2 is approval of the start of Title II or final/detailed design activities. In addition, it is intended that the program output will be in accordance with the EPA Guide for Conducting Treatability Studies Under CERCLA (EPA, 1989).

- DT\&E steps: In order to allow a consistent assessment of DT\&E needs, the activities are divided into the following logical steps (Figure IV-1-2). These steps are consistent with the EPA Guide for Conducting Treatability Studies Under CERCLA (EPA, 1989).

Primary paper evaluation: The objective of the primary paper evaluation is to study the various options using existing information. This evaluation will result in defining scope and conceptual design for the next steps of the DT\&E phase. It will eliminate those options that are not likely to be cost effective from further consideration.

Bench-scale studies: Bench-scale studies are the next logical step, but in some cases it is assumed that the DT\&E efforts can move directly from initial paper evaluation to the pilot-plant/prototype test studies. For example, evaluating a robotics operation in waste segregation would not be conducive to bench-scale studies. If required, these studies will address scaling issues. 


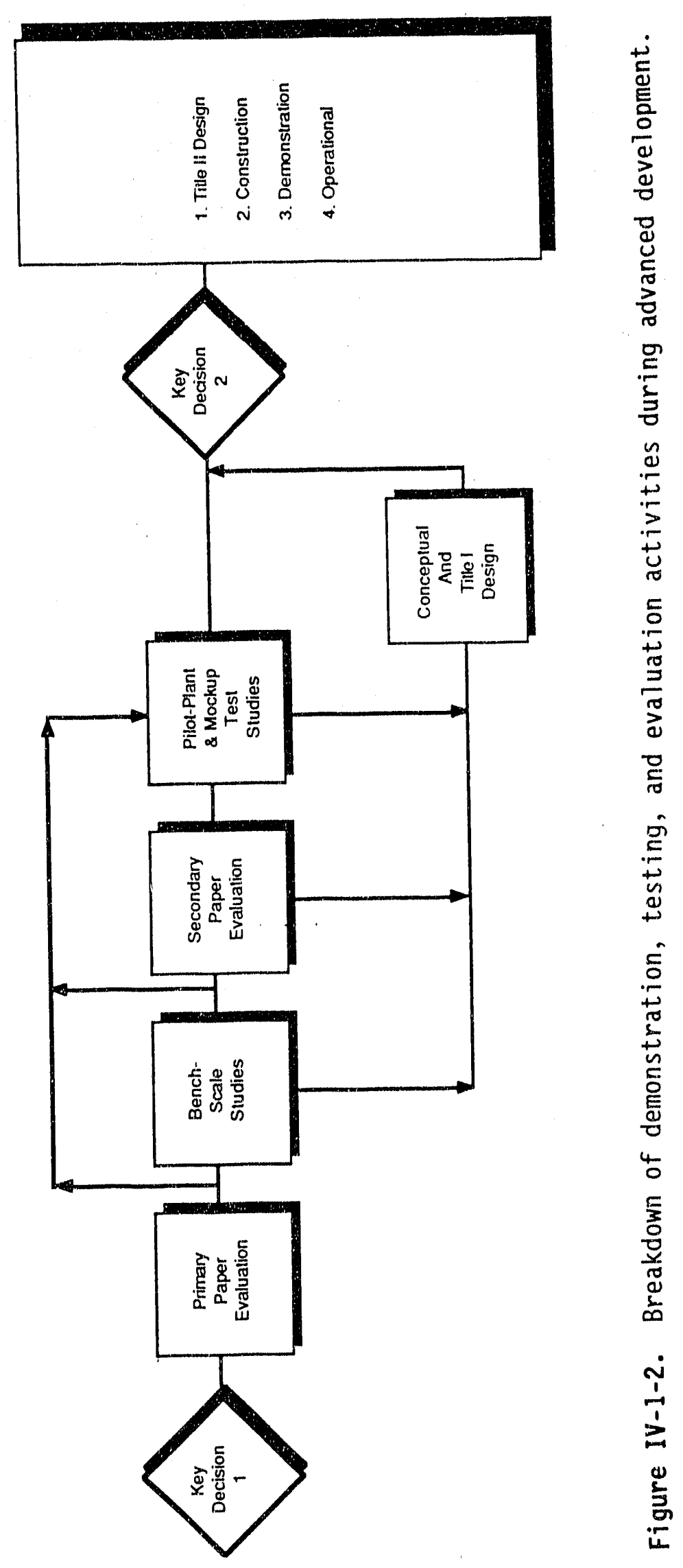

IV -18 
Secondary paper evaluation: When further pilot-scale studies are shown to be necessary, a secondary paper including more detailed concept development may be needed. This will help eliminate options that are not cost effective and focus the pilot or prototype test study on essential issues, normally using a single technology option.

- Pilot-plant/prototype test studies: The objective of pilotplant/prototype test studies is to provide reliable information for developing design criteria including scaleup limitations and cost estimates for processes and ancillary equipment. Ful1-scale prototype tests are assumed for non-process equipment such as robotics development. Generally, pilot-plant/prototype studies are assumed to cover only the critical portions of the equipment requiring advanced development.

- Number of technology options studied in a typical DT\&E program: It is assumed that primary paper evaluation, bench scale studies, and secondary paper evaluation steps will result in narrowing the alternatives to a single option. Pilot-plant/prototype studies are assumed to be applied only to the selected option and are proposed only if it is deemed necessary.

DT\&E lead-times: In order to provide a consistent estimate of the DT\&E lead-times, a set of timespans is assumed for the DT\&E steps. Based on the complexity of the technologies being considered, the timespan is narrowed down to a specific duration in the assessment sections of the system models. The timespans include allowances for a one-month procurement process and one-month report preparation for bench scale and paper studies. For pilotplant/mock-up studies, a 2-month procurement process, 2-12-month design, 4-12-month fabrication, and 6-24-month test and report preparation are assumed. Based on the above, the assumed timespans are 
- Primary paper evaluation

- Bench-scale studies

- Secondary paper evaluation

- Pilot-plant/mock-up test studies
5-6 months

5-18 months

5-6 months

14-60 months. 


\section{MELTING AND INCINERATION SYSTEM WITH LLW PRESORT (2-EG-1)}

This section presents scoping level preliminary systems descriptions and functional and operational requirements (F\&ORs) for a melting and incineration system concept where the low-level waste (LLW) is sorted out before thermal processing. The process is represented by the process functional flow diagram shown in Figure IV-2-1. The overall system process output is a final waste form material that is a high integrity leach resistant solid (glass ceramic/rock).

\subsection{Functional and Operational Requirements}

\subsubsection{System Description}

This system, as shown in Figure IV-2-1, is comprised of two thermal processes: melting and incineration. These technologies are combined to optimize waste processing applications of the technologies within the overall system and produce a leach resistarit, high integrity final waste form product (glass ceramic/rock).

The input waste stream is comprised of soi1, metals, and combustible and noncombustible waste. Soil is assayed during the retrieval process. clean soil is temporarily stored for future use as a backfill material. Contaminated soil is sent to the Soils Processing Subsystem (Volume VII). The LLW is sorted out up-front at the processing facility. Metals are sorted out during the retrieval process and sent to the Metals Decontamination and Sizing Subsystem (Volume VII). Similarly, LLW wastes are sorted and processed through the Low Level Waste Subsystem (see Volume VII). The TRU waste streams exiting from the three subsystems are returned to the melting furnace for processing along with the TRU noncombustible waste. The TRU combustible waste is incinerated, and the resulting ash is then processed in the melting furnace with the other TRU waste. Slag from the melter is packaged for disposal. The process off-gas streams are blended together and processed through an off-gas treatment system. 


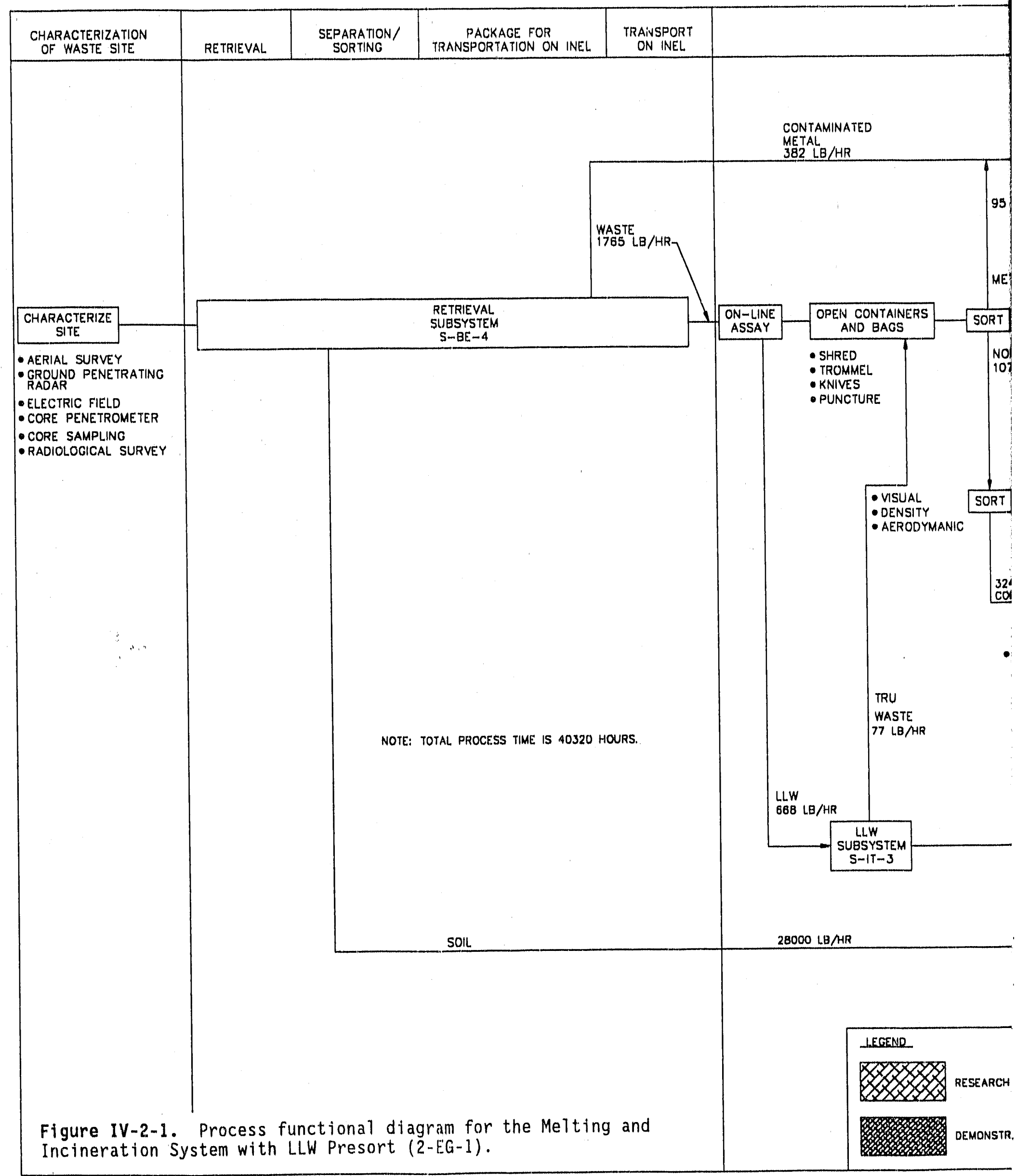




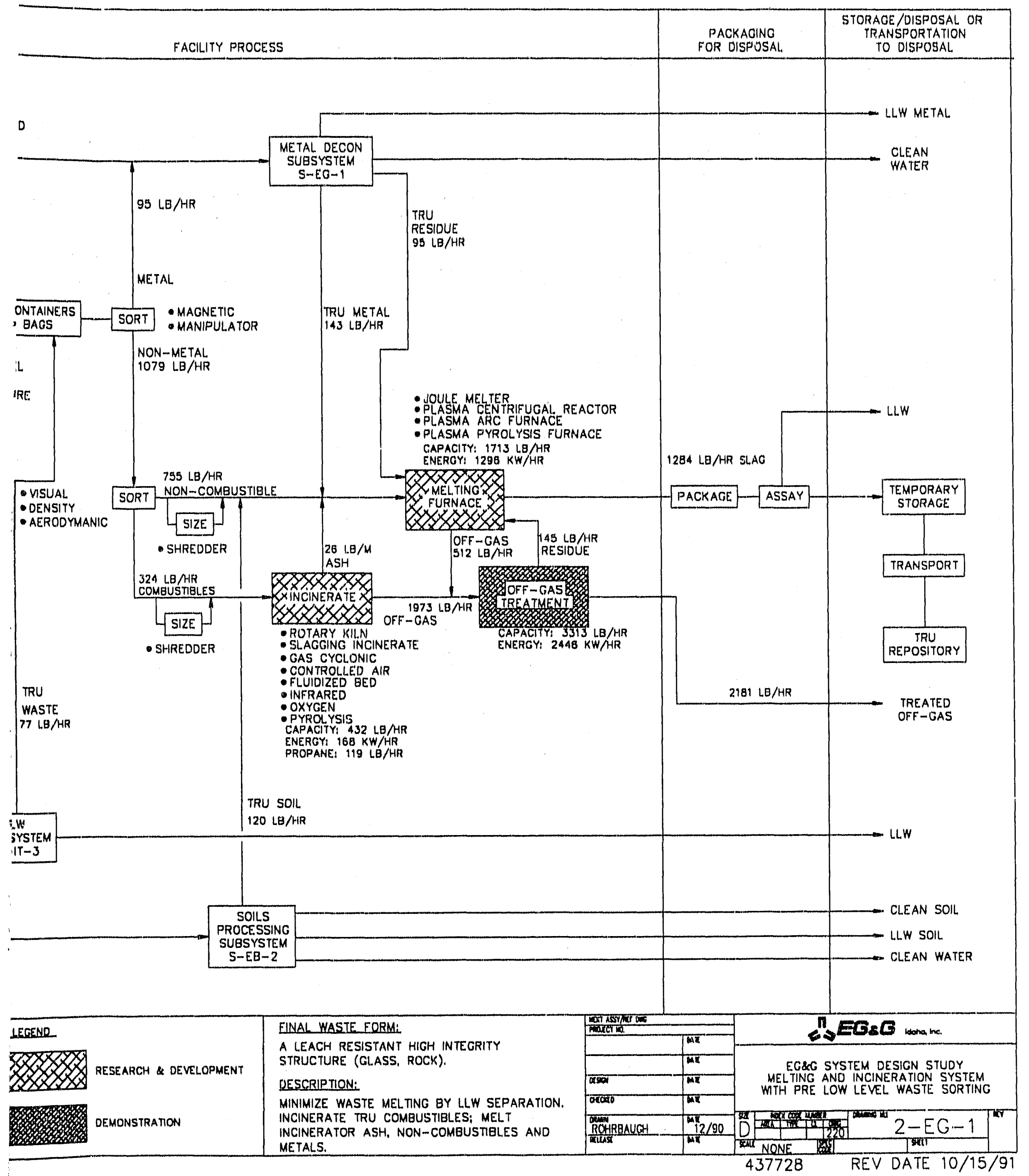




\subsubsection{System Boundartes}

The melting and incineraticin system boundary begins when the waste arrives at the processing factlity to be sorted. The L.LW is sorted up-front; the remaining waste is sorted into three streams for processing: the metals decontamination subsystem, the melting furnace (non-combustibles), or the incinerator (combustible).

Other inputs to the system include the following: TRU metals and sludge from the metal decontamination subsystem, TRU soll from the soll processing subsystem, and any TRU waste from the LLW subsystem.

The system boundaries end after the waste is packaged and assayed for TRU contamination, and the vitrified waste is efther sorted or transported to an appropriate disposal site.

The system off-gas boundary ends where the treated off-gas is emttted to the atmosphere.

\subsubsection{Process Functional Diagram}

The process functional diagram 2-EG-1 depicts the melting and incineration system and is shown in Figure IV-2-1.

2.1.3.1 On-1ine Assay. An on-line assay is performed to distinguish as much of the LLW waste from the TRU waste as possible. The LLW is transported to the LLW subsystem for processing. Any TRU waste from the LLW subsystem is returned to the melting and incineration system. Here it is sorted for metal decontamination or processing in either the melter or the incinerator.

2.1.3.2 Preliminary Sort. The waste containers are opened, and the metal that can be sorted from the waste by magnetic equipment and manipulators is sent to the metal decontamination subsystem for decontamination. Any metal that remains TRU-contaminated is returned to the melter with any TRU siudge from the metal decontamination processes. 
2.1.3.3 Secondary Sort. The combustible and noncombustible waste is sorted out for incineration and melting, respectively. The sorting is accomplished by visual inspection, operators, and by aerodynamic and density measuring equipment.

2.1.3.4 Size Reduction. The nonmetal waste is processed through a shredder. This reduces the waste in size to enable tt to be incinerated or vitrifted in the melter.

2.1.3.5 Incineration. Inctneration is a high-temperature thermal process (combustion oxidation) that treats incoming combustible (orgatnc) waste streams in the form of solids, sludges, or liquids. Nonconbustible (inert) waste components, such as soll or some metals, can also be tolerated in the process. Inctneration of waste typtcally occurs at temperatures ranging from 1800 to $2200^{\circ} \mathrm{F}$. At these temperatures, toxic organtc matertal is oxtdized (or pyrolized in the absence of suffictent oxygen) and unburned materials such as inerts remain as an ash. Noncombustibles for the most part pass through the incinerator unchanged. The ash from the incinerator is a waste effluent requiring further treatment and is subsequently processed in the melter with the primarily noncombustible waste streams. Some incinerators have the capability to operate in a slagging mode, wintch allows the inert ash to be partially molten, forming a vitrifted ash that might be sultable for final disposal. These slagging incinerators are, however, generally not as effective at melting or smelitng inerts as the high-temperature electric melters. The slagging incinerators require combustible fuel and are designed primarily as combustibles incinerators.

2.1.3.6 Melting. Melting technologies are high-temperature thermal slagging or vitrification processes that treat a wide varlety of feed wastes ranging from solids, liquids, metals, sludges, or soils. They are primarily intended to process inerts. A leach resistant slag is produced, dependent upon input materials, that is suitable as a final waste form for long-term storage or disposal. Melting technologies treat the waste at high temperatures, generally we 11 above $2000^{\circ} \mathrm{F}$, to vitrify and stabilize the 
Inorganic matertals including soll into a molten glassy slag that, upon cooling, forms a glass/ceramic leachuresistant solid.

The electric melting technologies are primartly destgned to slag or smelt inert materlals and do not require combustible fuels. These technologies can generally achleve much higher temperatures and have longer residence times required to produce a thoroughly mixed molten slag. As a part of the waste treatment process, they can also treat combustibles using combustion or pyrolysis.

2.1.3.7 Off-gas. Off-gas from both the incinerator and melting furnace systems is shown as treated in the same off-gas treatment system. The highest off-gas volumes $w 17$ be generated by the incinerator. The off-gas treatment residue is to be processed back through the melting furnace (Figure IV-2-1). Research and development effort is expected to be required to engineer a method to recover the volatile metals in the off-gas system and demonstrate the feasibllity of recapturing the volatile metals in the slag by reintroducing the residue containing condensed volatile metals into the slag. In the event that research and development efforts do not resolve this issue, the off-gas treatment residues could alternately be encapsulated in some other disposal media (e.g., grout).

\subsubsection{System Specific Assumptions.}

- Equipment: An electrically heated melter and a rotary kiln incinerator were chosen as the technologies for representing the melter and the incinerator within this processing system for energy and cost scoping purposes. This assumption was made to allow a typical mass energy balance calculation to be performed for costs scoping purposes, and does not mean that these technologies are necessarlly preferred.

- Waste characterization: The mass and composition of the input waste stream was based on information provided on the characterization of the waste at the SDA (Appendix A, 
Volume VIII). This information was refined as shown in Table IV2-1 and clarifted in the following assumptions according to the systems process functional diagram (Figure IV-2-1).

- The soll is sorted and processed in the solls subsystem; a small fraction of soil is assumed to remain in the waste stream. Table IV $-2-1$ shows this as being $15 \%$ of the mass contributed by concrete and soil. One percent of the TRU sotl sent to the solls processing subsystem is assumed to remain TRU contaminated and is returned to the melter for processing.

- The volume of TRU soil was given as $973,400 \mathrm{ft}^{3}$. The average soil density was assumed to be $1.86 \mathrm{~g} / \mathrm{cm}^{3}$ $\left(116.3 \mathrm{lb} / \mathrm{ft}^{3}\right)$ from the information provided on the characterization of the waste at the Subsurface Disposal Area (SDA). This gives a weight of $51,261,231 \mathrm{~kg}$ $(113,011,531 \mathrm{lb})$ of TRU soil processed through the soil processing subsystem. One percent of this, or $512,612 \mathrm{~kg}^{\mathrm{a}}$ $(1,130,104 \mathrm{lb})$, was assumed to remain TRU contaminated and was sent to the melter for processing.

The waste arriving at the processing facility is $40 \% \mathrm{LLW}$. This $L L W$ is sorted out up-front and processed in a $L L W$ subsystem.

The TRU-contaminated metals are processed in the metals decontamination subsystem. A fraction of the metal is assumed to be undetected and remains in the waste stream.

a. During final review of this study, it was judjed that costs associated with soil processing operations to achieve this concentration/separation efficiency may be very high and may not be justified because (a) more soil may be needed for the melter, and (b) separation at this level of efficiency may not be needed. Additional optimization trade-off studies will be needed in the future. 
Tabie IV-2-1. Mass and volume of waste by category

\begin{tabular}{|c|c|c|c|}
\hline Category & $\begin{array}{l}\text { Weight } \\
(\mathrm{kg})\end{array}$ & $\begin{array}{l}\text { Weight } \\
(1 \mathrm{~b})\end{array}$ & $\begin{array}{l}\text { Volume } \\
\left(\mathrm{ft}^{3}\right) \\
\end{array}$ \\
\hline Combustibles (sent to incinerator) & $4,105,096$ & $9,050,094$ & 684,042 \\
\hline Sludges (to plasma furnace) & $7,270,984$ & $16,029,612$ & 460,399 \\
\hline $\begin{array}{l}\text { Metals ( } 15 \% \text { that was undetected and } \\
\text { sent directly to plasma furnace) }\end{array}$ & 571,114 & $1,259,080$ & 17,997 \\
\hline $\begin{array}{l}\text { TRU-contaminated metals from metal } \\
\text { decontamination subsystem ( } 30 \text { lb of } \\
\text { metal for every } 100 \text { ib of metal sent } \\
\text { to metal decontamination subsystem) }\end{array}$ & $1,618,159$ & $3,567,393$ & 50,993 \\
\hline $\begin{array}{l}\text { TRU residue from metal } \\
\text { decontamin-tion subsystem waste } \\
\text { treatment ( } 201 \mathrm{~b} \text { for every } 1001 \mathrm{~b} \text { of } \\
\text { metal sent to metal decontamination } \\
\text { subsystem) }\end{array}$ & $1,078,772$ & $2,378,261$ & unknown \\
\hline $\begin{array}{l}\text { Concrete, soil ( } 85 \% \text { concrete, } 15 \% \\
\text { soil) }\end{array}$ & $1,368,880$ & $3,017,834$ & 63,758 \\
\hline $\begin{array}{l}\text { TRU soit from the soil processing } \\
\text { subsystem ( } 1 \% \text { of the TRU soil } \\
\text { processed at the soil processing } \\
\text { subsystem) }\end{array}$ & 512,612 & $1,130,104$ & 9,718 \\
\hline Glass, filters, insulation & 241,737 & 532,933 & 28,601 \\
\hline $\begin{array}{l}\text { Miscellaneous: } \\
\text { plastic, resin, } \mathrm{Li}, \mathrm{Hg}\end{array}$ & 347,961 & 767,115 & 38,366 \\
\hline TRU waste from LLW subsystem & unknown & unknown & unknown \\
\hline Total & $17,115,321$ & $37,732,426$ & $1,353,374 t$ \\
\hline \multicolumn{4}{|c|}{$\begin{array}{l}\text { a. The initial weight and volume of the waste were obtained from } \\
\text { the unpublished research results of } C \text {. R. Edinborough, EG\&G Idaho, Inc., } \\
\text { Idaho Falls, Idaho, August } 15,1990 \text {. }\end{array}$} \\
\hline
\end{tabular}


Table IV-2-2 shows this as being 15\% of the mass contributed by the TRU-contaminated metals.

- The amount of TRU-contaminated metal and decontamination waste treatment residue (assumed to be high in metals) returning to the melter was determined. The total weight of metals was given as $6,345,720 \mathrm{~kg}(13,989,901 \mathrm{lb})$ in the information provided on the characterization of the waste at the SDA. It was assumed that $60 \%$ of this is TRU-contaminated metals and that $15 \%[57], 115 \mathrm{~kg}$ $(1,259,308 \mathrm{lb})]$ of the TRU-contaminated metals were not sorted and went directly to the melter. The rest went to the metal decontamination subsystem, $(5,393,862 \mathrm{~kg}(11,898,860 \mathrm{lb})$. Assuming that for every 100 lb of metal processed by the metal decontamination subsystem, $301 \mathrm{~b}$ remains TRU-contaminated metal and $20 \mathrm{lb}$ is generated as decontamination waste treatment residue; there is $1,618,159 \mathrm{~kg}(3,568,041 \mathrm{lb})$ of TRU-contaminated metal and 1,078,772 $\mathrm{kg}(2,378,692 \mathrm{lb})$ of decontamination waste treatment residue for melter processing.

- Mass flow rates: A summary of the estimated mass flow rates for the system are shown in Figure IV-2-1.

- The off-gas from the incinerator is cooled and filtered, combined with that from the electric melter, and then processed through a generic off-gas treatment system. The off-gas system model assumed resembles the Pacific Northwest Laboratories off-gas system being used for ISV off-gas processing. This is an established system that can handle radionuclides, particulates, and acids.

- Unit operation capacities: The unit operation capacities are based on the mass of waste that must be processed over a ten-year period. The unit operation estimated capacities are listed in Table IV-2-3. 
Table IV-2-2. Assumed composition of buried waste combustibles ${ }^{a}$

\begin{tabular}{|c|c|}
\hline Category & $\begin{array}{l}\text { Weight } \\
(\%)\end{array}$ \\
\hline Wood & 0.87 \\
\hline Paper & 61.42 \\
\hline Polyethylene & 15.63 \\
\hline Cloth & 14.70 \\
\hline Graphite & 0.15 \\
\hline Rubber & 1.02 \\
\hline Cardboard & 0.29 \\
\hline Teflon & 0.09 \\
\hline Metal & 1.00 \\
\hline Cement & 0.29 \\
\hline Sand & 1.60 \\
\hline PVC Plastic & 2.94 \\
\hline \multicolumn{2}{|c|}{$\begin{array}{l}\text { a. Based on the composition of combustible } \\
\text { wastes from the Process Experimental Pilot } \\
\text { Plant. }\end{array}$} \\
\hline
\end{tabular}


Table IV-2-3. Unit operation estimated capabilities

\begin{tabular}{ll}
\hline \multicolumn{1}{c}{ Equipment } & \multicolumn{1}{c}{ Capacity } \\
Incinerator & $2251 \mathrm{~b} / \mathrm{h}\left(679 \mathrm{ft}^{3}\right) \odot 1800^{\circ} \mathrm{F}$ \\
Electric melter & $7121 \mathrm{~b} / \mathrm{h}$ \\
Melter cooling water & $25,0001 \mathrm{~b} / \mathrm{h}$ \\
Off-gas system & $16361 \mathrm{~b} / \mathrm{h}$ \\
Off-gas cooling water & $53,011 \mathrm{lb} / \mathrm{h}$ \\
\hline
\end{tabular}

- Unit operation energy requirements

- Incinerator: The energy requirements are based on the necessary energy requirements to operate an incinerator with a mass flow rate of $225 \mathrm{lb} / \mathrm{h}$. The energy requirement is approximately $117 \mathrm{kWh}$ for electrical power and $83 \mathrm{lb} / \mathrm{h}$ for propane consumption.

- Melting furnace: The energy requirements, based on the necessary energy requirements to operate a melter with a mass flow rate of $712 \mathrm{lb} / \mathrm{h}$, is estimated to be approximately $1 \mathrm{MW}$.

- Off-gas system: Off-gas system energy requirements are estimated to be approximately $1570 \mathrm{~kW}$.

\subsubsection{Facility Description}

A scoping layout of the processing facility is shown in Figure IV-2-2. only the processing areas are identified. Sections of the building would be two or three stories high for the processing areas in order to contain the operating equipment. Sections of the building not shown would include storage areas, a maintenance area, locker rooms, health physics areas, and a general office area. 


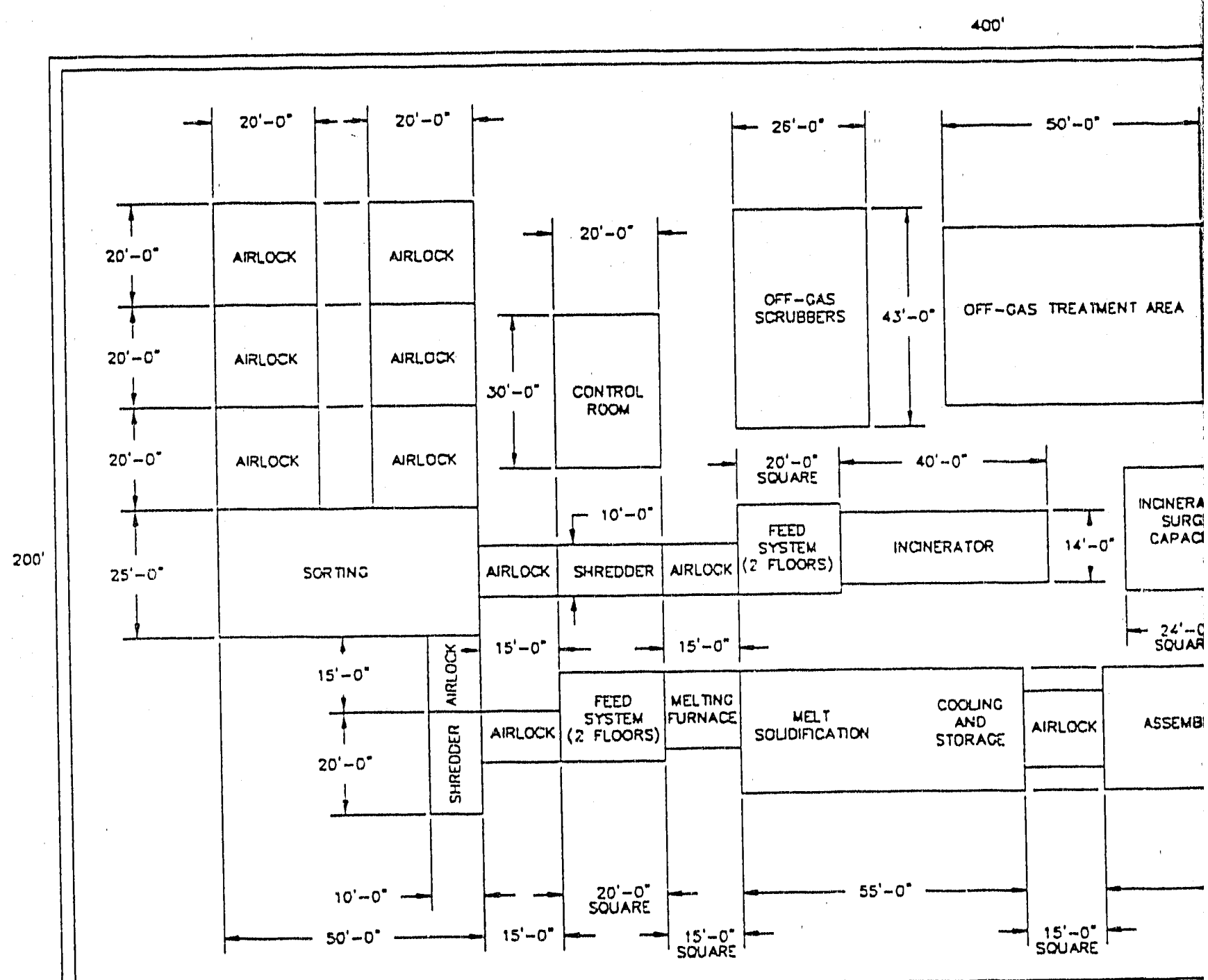

Figure IV-2-2. Layout of the processing facility for the Melting and Incineration System with LLW $F$ 


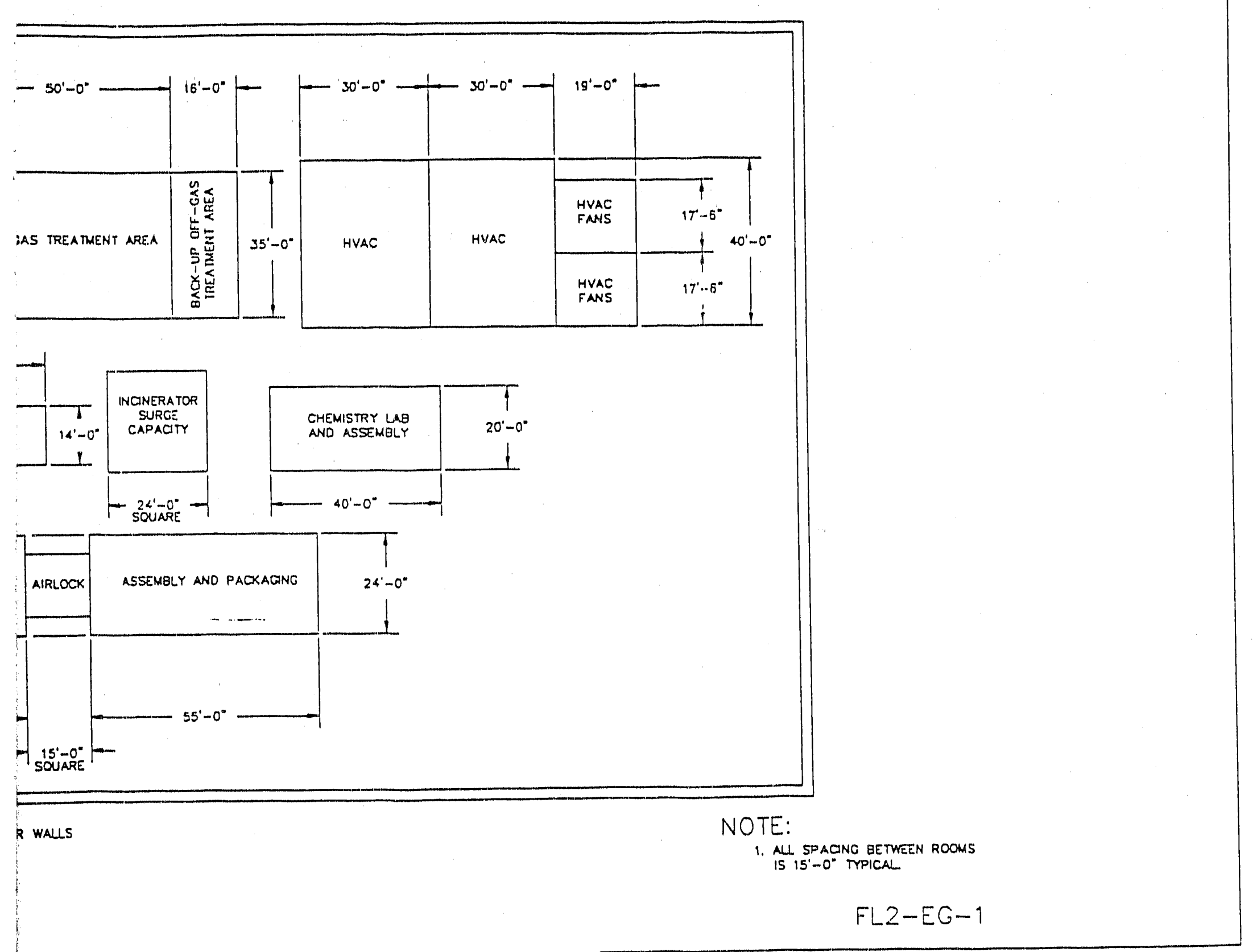

tem with LLW Presort (2-EG-1). 


\subsubsection{System Design Requirements}

2.1.5.1 Functional Requirements. The function of the melting and incineration system is to transform incoming waste from its present form into a leach-resistant, high integrity structure such as glass or rock. The system is to process the buried TRU waste at RWMC within a ten-year period, while meeting a11 of the current and anticipated requirements of EPA, RCRA, and CERCLA.

The overall processing facility will be classified as a moderate hazard facility per UCRL 15910 and must also meet the requirements for a solid radioactive waste facility per DOE order 6430.1A.

The off-gas system is to have the capacity to handle $1636 \mathrm{lb} / \mathrm{h}$ of off-gas, including the gas generated from both the melting furnace and the incinerator. The off-gas system wi11 meet the EPA requirements for stack emissions.

\subsubsection{Interface Requirements}

2.1.6.1 Retrieval Subsystem. The Retrieval Subsystem (Volume VII) will retrieve the waste and transport it to the melting and incineration facility where it wi11 be sorted into the appropriate waste processing stream (LLW, metal, combustible, and noncombustible). The soil will be separated out during the retrieval process.

2.1.6.2 Low-Level Waste Subsystem. The LLW sorted from the waste before processing will be transported to the LLW subsystem (Volume VII) for processing. Any resulting TRU waste from the LLW subsystem wi11 be returned to the melting and incineration facility for treatment.

2.1.6.3 Soils Processing Subsystem. The soil sorted from the waste during retrieval will be transported and processed in the Soil Processing Subsystem (Volume VII). Any soil that does not meet the LLW acceptance criteria will be returned to the melting and incineration facility and solidified in the melting furnace. 
2.1.6.4 Metals Processing. The TRU metals sorted from the waste will be transported to the metal decontamination subsystem (Volume VII) for decontamination. Metal that cannot be decontaminated to meet the LLW criteria will be returned to the melting facility and solidified in the melting furnace.

2.1.6.5 Power. Electrical power to operate the facility equipment, controls, and lighting will be sufficient to operate the facility under standard design requirements and to safely shut down the facility under emergency conditions.

2.1.6.6 Utilities. Utility systems will be provided to support the facility, (e.g., potable water, plant air, instrument air, breathing air, steam, and sewer). These systems will be sufficient to operate the facility while it is operating under normal and anticipated abnormal operating conditions and under emergency conditions.

2.1.6.7 Miscellaneous systems. The processing facility will be provided with communication and alarm systems and will include: telephone systems, evacuation, fire, security alarm systems, and public address systems. The processing equipment will automatically shut down upon activation of the fire system or activation of the evacuation alarm.

\subsection{System Assessment}

This section discusses in general the status of the level of development of some potential technologies available for each of the unit operations in the systems options. A qualitative assessment is provided of the risks associated with each unit operation and some of the unit operations' strengths and weaknesses are noted. It should be noted that these are preliminary scoping assessments based on the subjective judgment and existing knowledge of the preparers. Additional technology evaluations are needed prior to selecting particular component technologies, and to identify detaild development and demonstration needs for selected technologies. 


\subsubsection{Current Status of Unit Operations}

The state of development for the unit operations in process functional diagram are presented in the following paragraphs. This information is summarized for all the technologies in Table IV-2-4.

2.2.1.1 On-Line Assay. An on-line assay is performed on the waste when it arrives at the waste facility. Assay capability is required for TRU concentrations at $100 \mathrm{nCi} / \mathrm{g}$ at production capacity for uncharacterized waste.

2.2.1.2 Open Containers and Bags. The waste containers are opened by techniques typically used in the municipal and nuclear waste industry and use shredders, trammels, knives, and puncturing devices. These techniques are available and have been proven as feasible methods.

2.2.1.3 Metal Sorting. The incoming waste containers are opened, and the waste is segregated into two streams: metals and nonmetals. This sorting is done manually with magnetic separation and with manipulators. To facilitate remova1, the nonmagnetic metallic portion of the waste is artificially magnetized by electrically-produced currents. There are several magnetic techniques available that are applicable for the buried waste, for example, magnetic-head pulleys, suspended magnets, magnetic drums, and plate magnets. A11 of these magnetic techniques as well as manipulators are available commercially and have been proven industrially as feasible methods.

2.2.1.4 Combustible Sort. The combustible and noncombustible wastes are separated from each other by visual inspection, density equipment, and aerodynamic equipment. Visual inspection is conducted by operators utilizing manipulators to segregate the waste. 


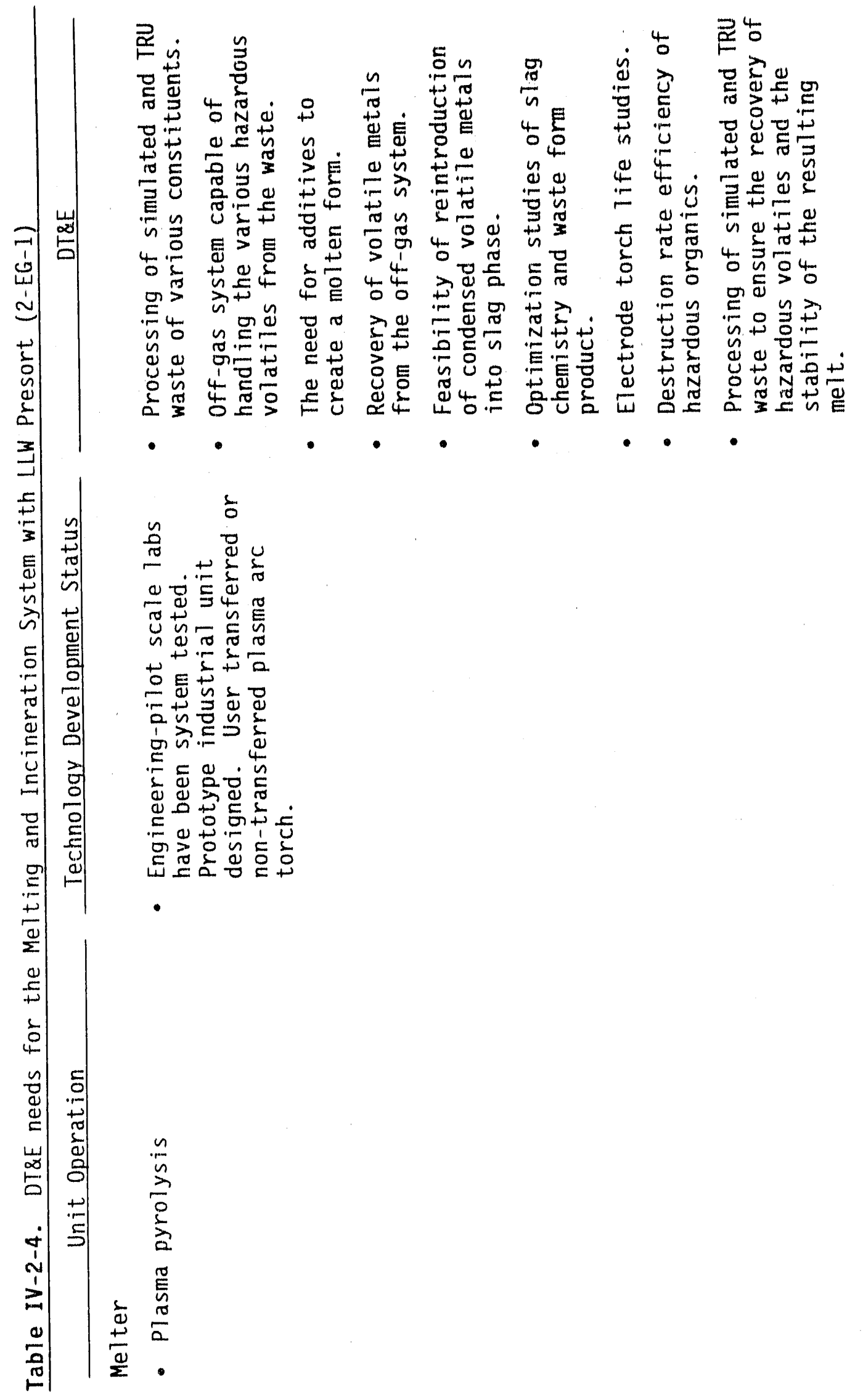




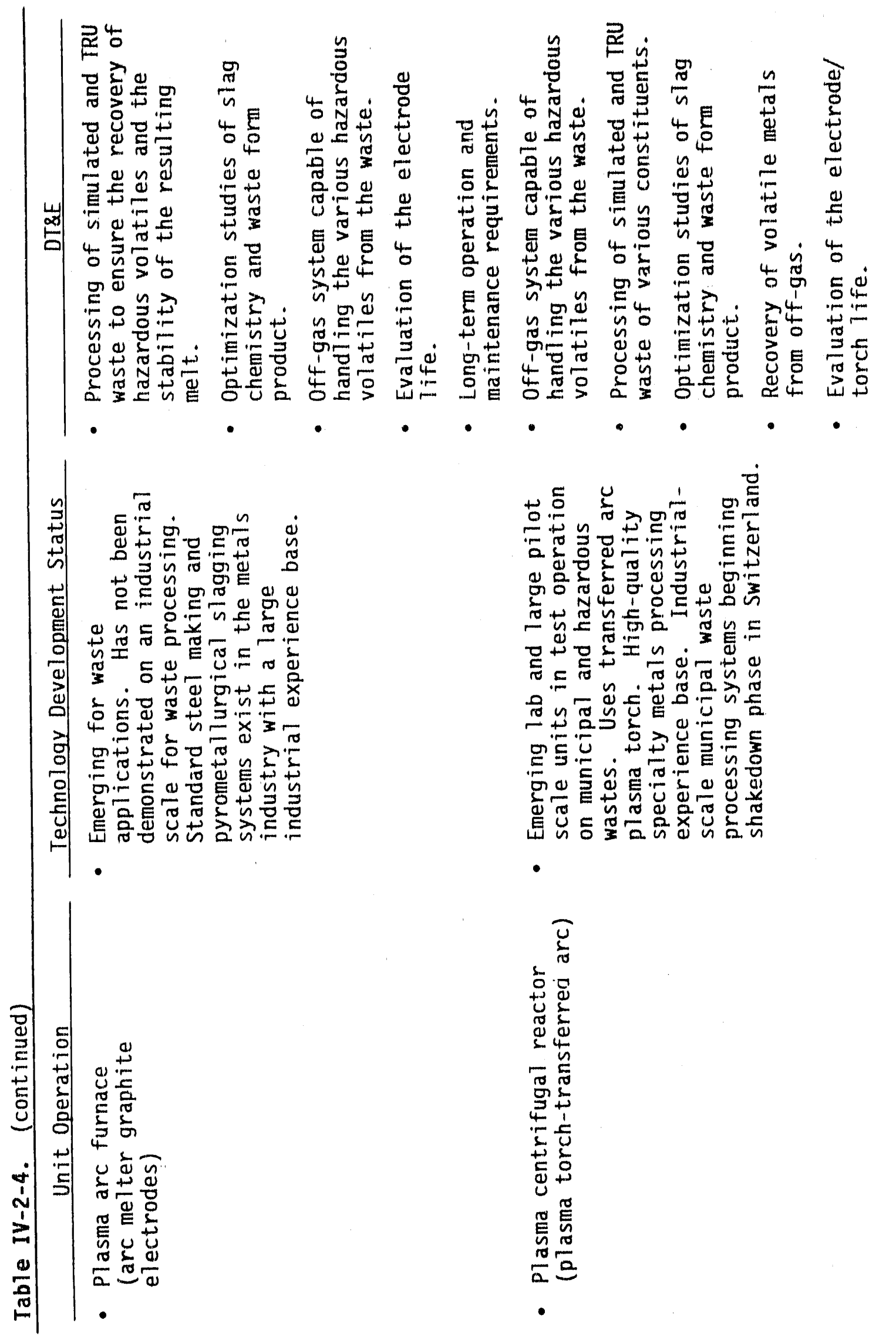




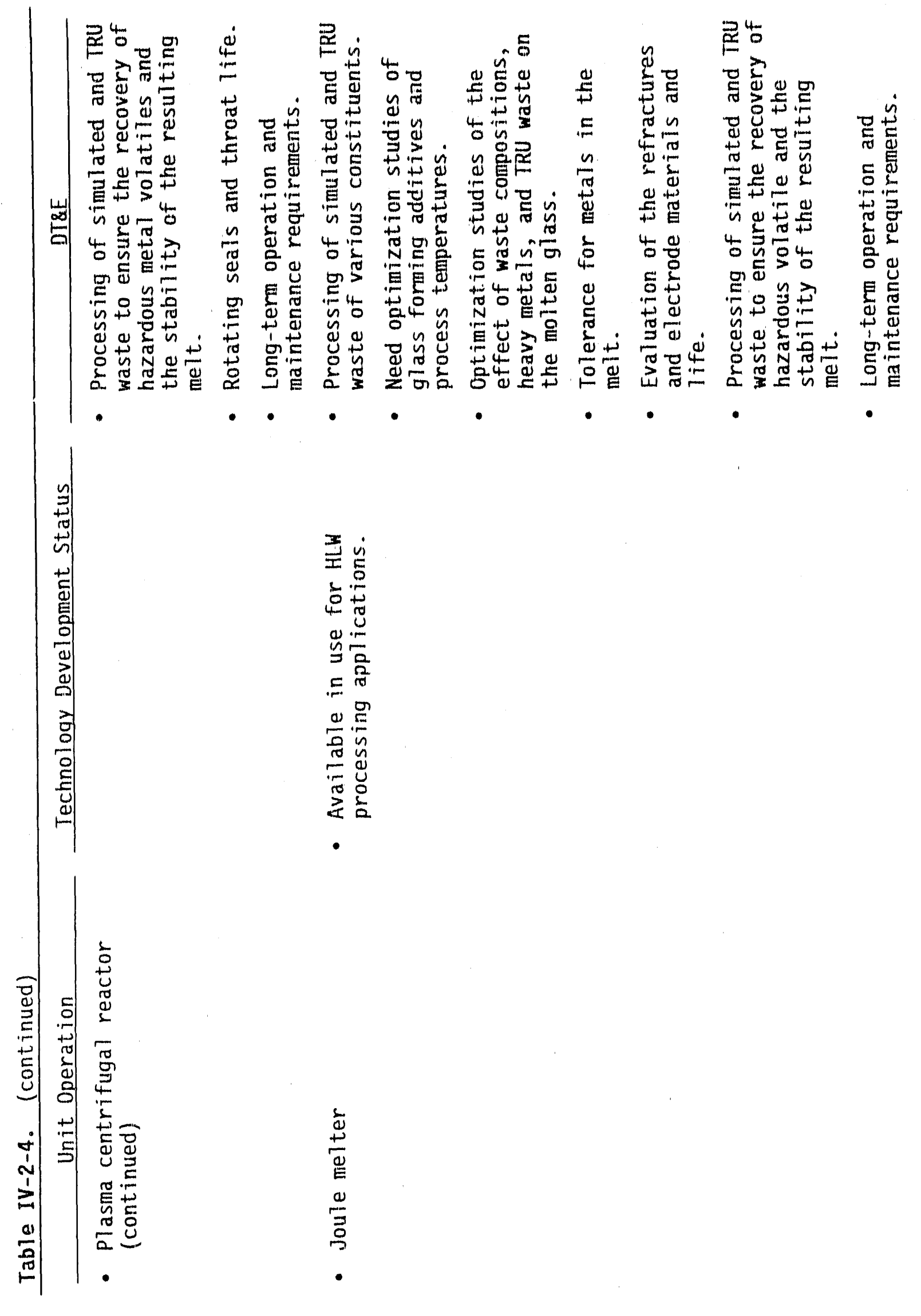




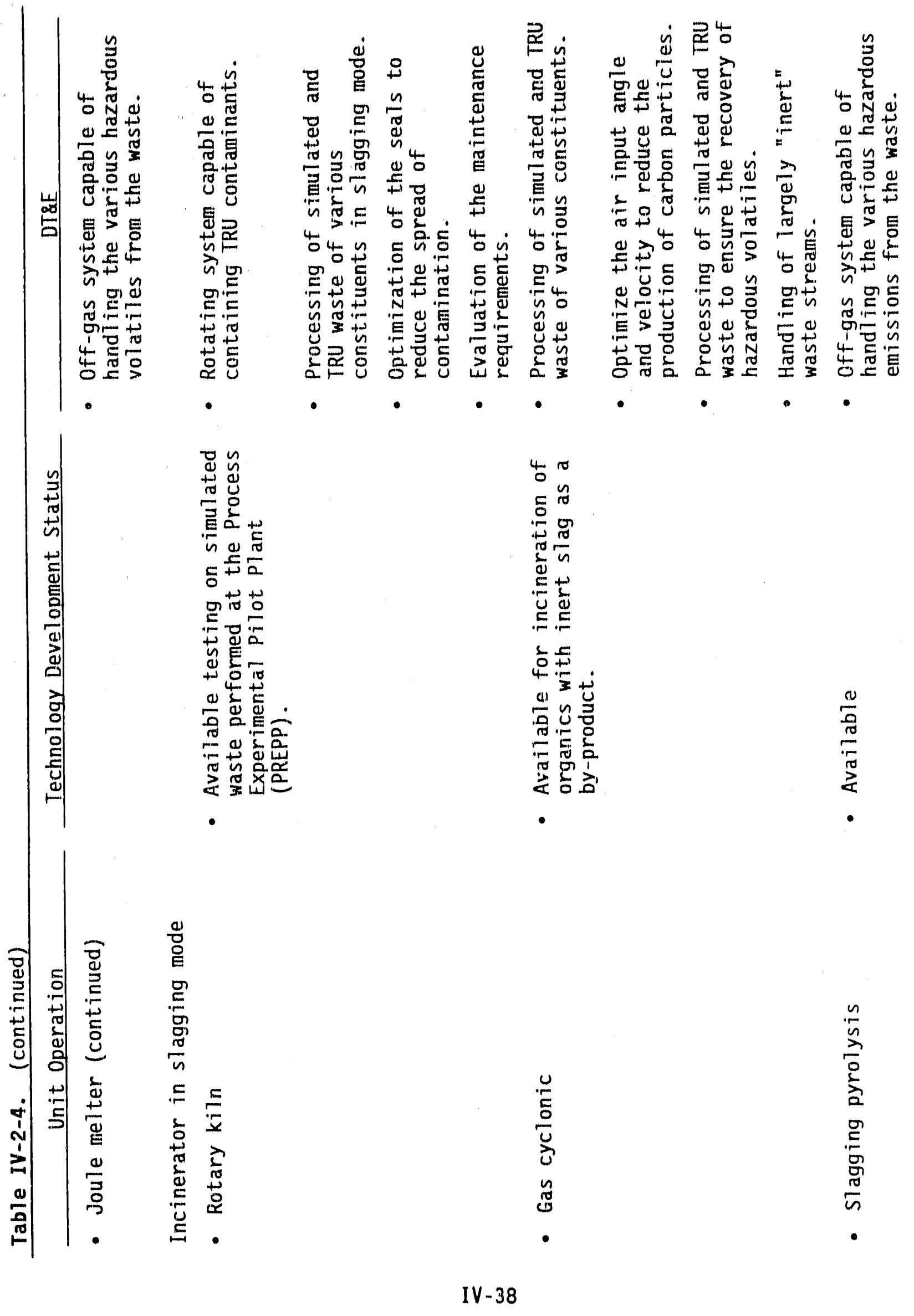




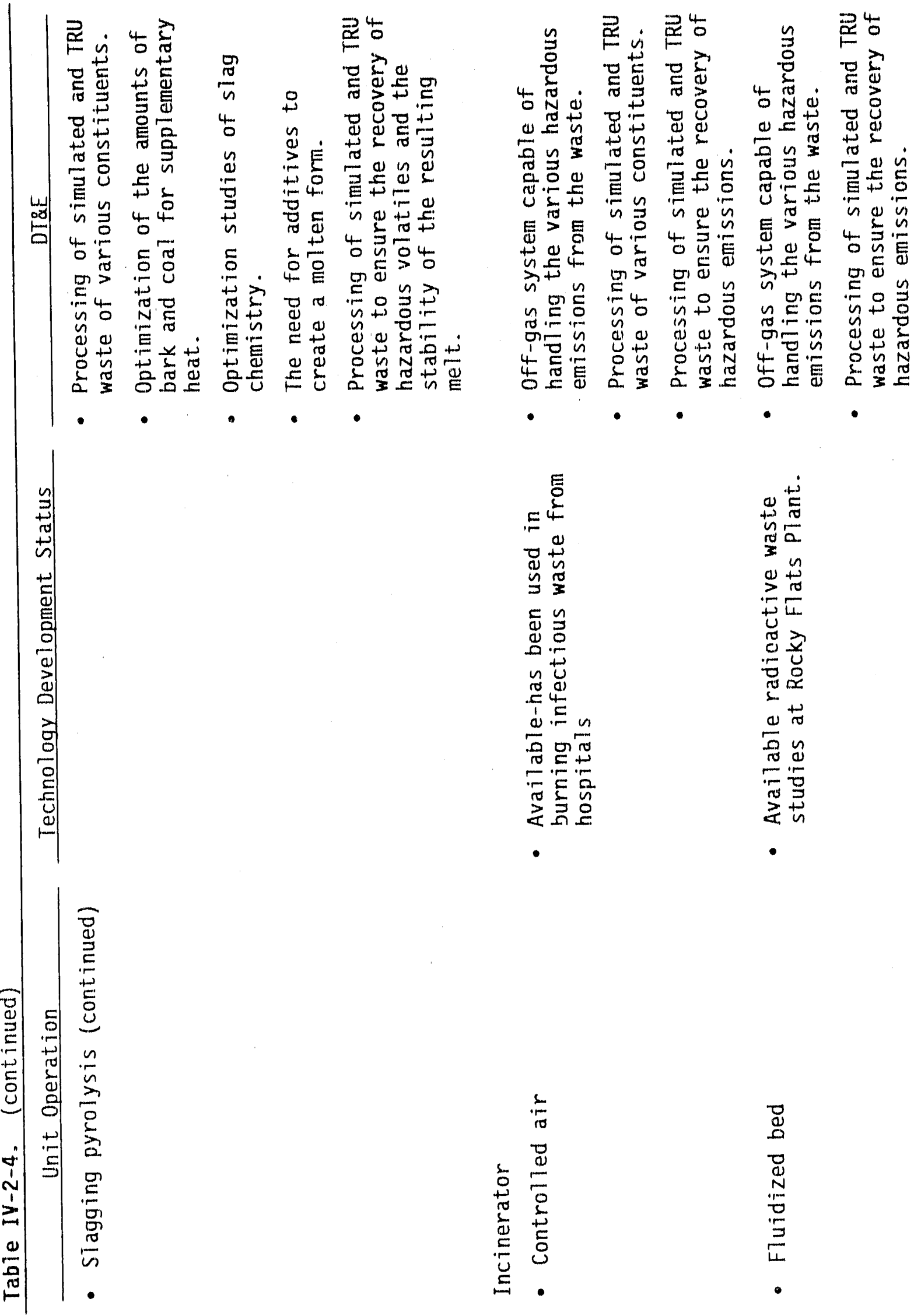




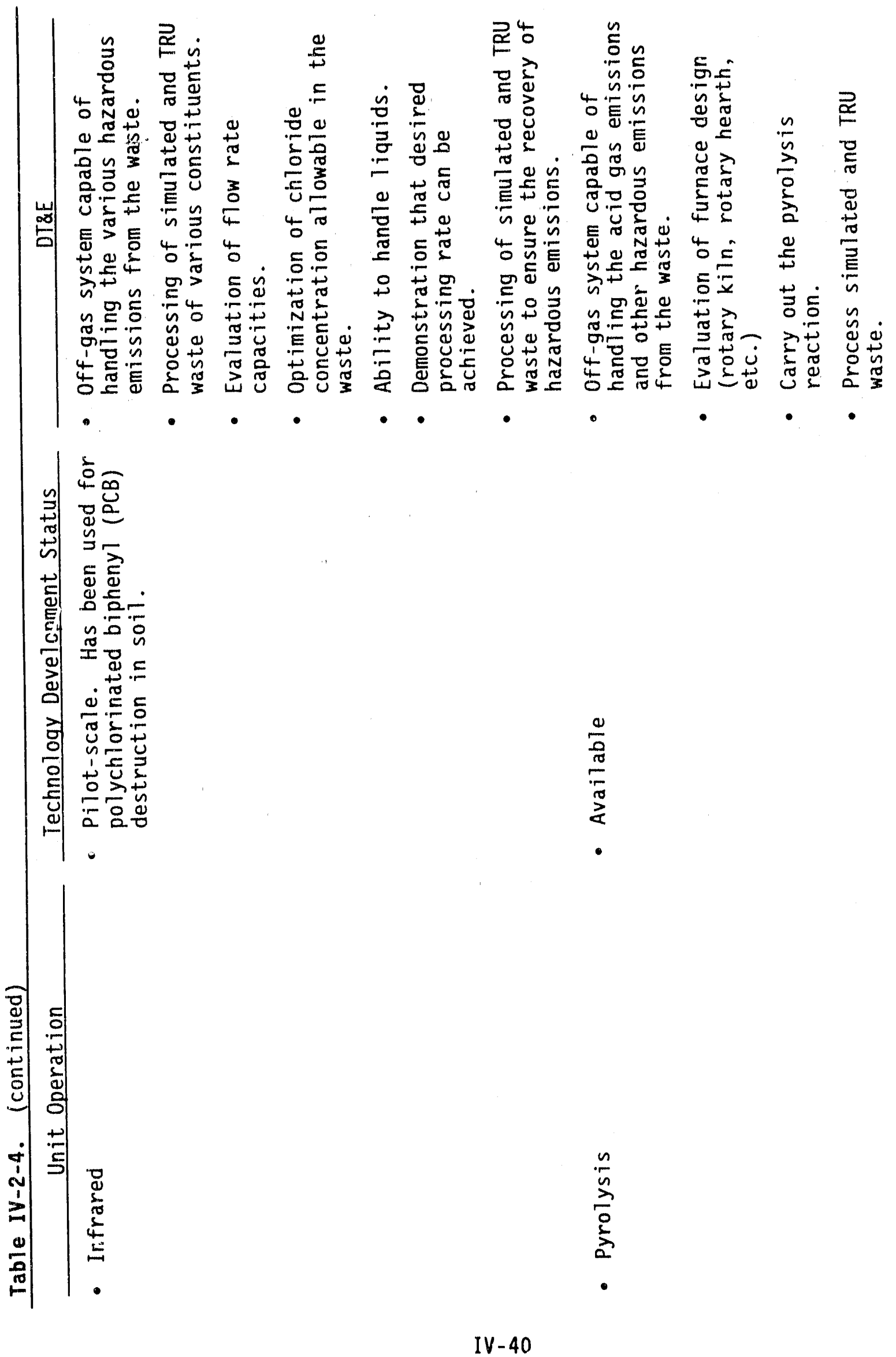




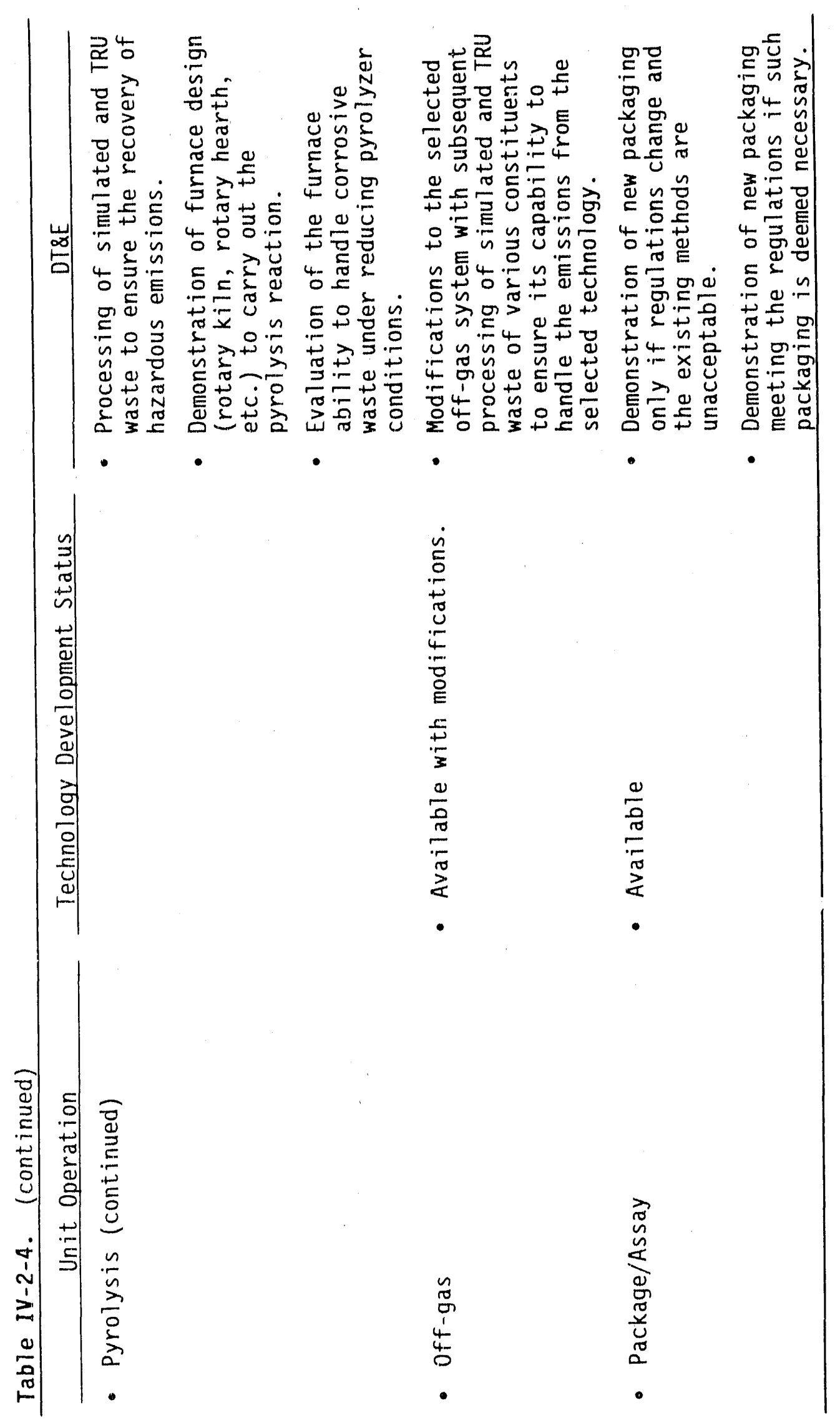


Density equipment encompasses gravity separation as the means for separating the combustible waste (less dense) from the noncombustible waste (more dense). Density techniques available and applicable to separating buried waste include the cyclone separator, dense-media cone separator, revolving-drum type dense media separator, and the drag-tank separator. These are commercially available and have been proven in metallurgical endeavors.

The waste can also be separated by aerodynamic means, which involve the use of air to separate the less dense material from the more dense material within a closed system. This is also commercially available.

2.2.1.5 sizing. The combustible and noncombustible waste is shredded before to further processing. Shredders are available commercially and have been shown feasible in a wide variety of applications. Cryofracture is a relatively new process that has been used in processing deferise waste. Cryofracture would require development and demonstration on sample waste streams. This process may not be suitable for size reducticn of stainless steels.

2.2.1.6 Melting. The plasma and Joule melter systems are generally favorable for melting purposes because of the low off-gas levels involved with heating. Other systems involving fuel combustion are subject to major off-gas treatment requirements. Several melting technologies exist, the status of those considered for treating the buried waste are discussed in the following paragraphs.

- Plasma pyrolysis reactor--Plasma Energy Corporation: The plasma pyrolysis furnace developed by Plasma Energy Corporation (PEC) uses a pyrolysis reaction to break the waste into its atomic constituents. Air is used as the plasma gas and enters through the torch. To create the pyrolysis condition, steam is injected into the plasma furnace. PEC has conducted plasma waste conversion tests at a rate of 1 ton/h (24 ton/d), converting municipal solid waste (MSW) into a fuel-laden gas and a vitrified inert solid. The results of these test have been used to design a 250 ton/d module plasma pyrolys is furnace. The size capacity has been demonstrated (24 ton/d) as 
adequate. The unit requires a steam source (i.e., a boiler not required by other systems). The process data are highly dependent on the waste type and the thermal requirements to transform the waste are directly related to the energy requirements, torch power, and throughput capacity of the system. The areas where this unit needs research, development, and demonstration tests are in showing that this technology can be applied to TRU-contaminated waste and that the technology surrounding the off-gas system has the capability to recover volatilized metals. Optimization studies of the slag chemistry are needed for metals stabilization. Typically elemental metals such as lithium, arsenic, mercury, cadmium, zinc, and lead can be volatilized in this process.

- Plasma arc furnace: The plasma arc furnace (PAF) uses the energy from a plasma arc torch to melt and vitrify the inert waste components. This approach is similar to the PEC plasma torch furnace and PCR techniques except it uses a graphite electrode and a very short transferred arc. The plasma arc furnace can supply very large amounts of power and achieve very high bath temperatures for processing of natural materials, such as soil, with high melting temperatures. There are similar gaps in waste application knowledge in slag chemistry and final waste form optimization.

This technology unit needs research, development, and demonstration tests to show its applicability to treating TRU waste to optimize TRU and metals, slag chemistry for metal oxide stabilization, and evaluation of electrode 1 ife. Demonstration of the technology surrounding the off-gas systems capability to recover volatilized metals and to reintroduce the condensed volatile metals back into the slag phase is also needed.

- Plasma centrifugal reactor: The plasma centrifugal reactor (PCR) developed by Retech (currentiy under testing at pilot scale at CDIF, Butte, Montana) uses heat from a plasma arc torch to incinerace 
organic wastes and melt inerts to produce a molten slag. The PCR is an emerging technology that is in the process of being demonstrated at the pilot-scale; however, throughput capacity has not been demonstrated. The process data are highly dependent on the waste type. The thermal requirements to transform the waste are directly related to the energy requirements, torch power, and throughput capacity of the system. The off-gas volumes are kept very low by using an air plasma. This unit needs DT\&E tests to show its capability to treat TRU-contaminated waste and in the technology surrounding the off-gas systems capability to recover volatilized metals and to reintroduce the condensed volatile metals back into the slag phase. Also needed are optimization studies of the slag chemistry for metals stabilization and evaluation studies of electrode 1 ife and rotating seal/throat 1 ife. This system with oxygen addition may have high potential for combined incineration with ash melting. However, because of mechanical complexity, it is questionable whether this system is maintainable with TRUcontaminated materials being processed.

- Joule melter: A joule melter or molten-glass process uses the principle of joule heating to melt glass formers and dissolve inert solids. Electrodes partially submerged in the molten glass supply an electrical energy (resistance heating) to molten glass, and the wastes are fed to the pool of molten glass. INEL soils have been shown to be a good glass-forming feed stock but have a very high natural melting temperature of $\approx 1600^{\circ} \mathrm{C}$. Alkanine based additives are required to lower viscosity/melt temperature for processing within the capability of electrode and refractory materials.

Periodically, the molten glass is drained off and cast to molds or granulated. This process is commercially available at $6 \mathrm{t} / \mathrm{h}$ for noncombustibles and non-TRU feed stock. The submerged electrode joule melter will be a minimum off-gas producer for inert melting; no steam or air is required in the process. It is not suitable for combustibles without added oxygen combustion equipment. Vertical and 
horizontal glass melters have been demonstrated for high level waste glasses. A vertical glass melter has been demonstrated by Pacific Northwest Laboratories for high-level noncombustible nuclear waste with a processing rate of 1-3.5 $\mathrm{ft}^{3} \cdot(47-163 \mathrm{lb} / \mathrm{h}$, average waste density of $47 \mathrm{lb} / \mathrm{ft}^{3}$ ) for every $10 \mathrm{ft}^{2}$ of exposed $\mathrm{glass}$ surface area in the melting cavity. Larger systems have been designed up to 7 $\mathrm{ft}^{3} / \mathrm{h}(325 \mathrm{lb} / \mathrm{h})$ and 1 arger systems are considered available.

Combustible waste that requires a drop tube has been processed at a rate of about $2 \mathrm{lb} / \mathrm{h}$. Combustible waste must be processed slower to ensure proper scrubbing of the resulting particulates that are produced. Other sources state that horizontal melters 4 by $23 \mathrm{ft}$ long are capable of treating wastes at $485 \mathrm{lb} / \mathrm{h}$ and that larger furnaces could be constructed to accommodate higher processing rates. Based on this information, it appears likely that a $1000 \mathrm{lb} / \mathrm{h}$ glass melter could be built to meet our conceived flow rate requirements of 9 ton/d. The molten-glass process can be applied to a variety of waste, and the resulting off-gas emissions will be directly related to the waste constituents. Development, and demonstration tests are needed in the area of the off-gas systems capability to handle excessive amounts of chloride, volatilized metals, slag chemistry optimization, metals handling, and other such materials.

2.2.1.7 Incineration: Several incineration methods exist, the status of these with respect to treating the buried waste are disclissed in the following paragraphs.

- Rotary kiln: The incineration of wastes with rotary kiln (RK) incinerators is quite popular. The designs, concepts, and theories are we11-established and proven in many solids-processing industries. However, to meet INEL needs, research, development, and demonstration would be required to ensure the applicability to TRU waste. The offgas emissions will be directly related to the waste constituents. Shredded TRU-free combustibles can be processed in existing rotary kiln furnaces. Volatile metals can be a problem, however, this 
technique may be the lowest cost solution to simple combustion waste. Although some work has been done, research, development, and demonstration w111 be necessary to ensure that the radioactive and hazardous constituents can be handled.

- Gas cyclonic furnace: Cyclonic furnaces are an avallable incineration technology used in the combustion of coal for electric power generation. Versions have also been used for the destruction of medical infectious combustible wastes from hospitals. The size capacity has been demonstrated for a wide range of flow rates. Nonradioactive waste has been burned without the use of an afterburner on the exhaust. Some research, development, and demonstration tests should be done to ensure that this type of furnace can be adapted to TRU waste and to determine if modifications are necessary to meet the necessary air emissions regulations. This process may be most suitable for combined combustibles and noncombustible treatment. There are high gas volumes and large offgas quantities with dilute volatiles, which may be a major problem. In addition, cyclonic furnaces can be operated in a slagging mode to produce a molten slag, although they require large amounts of auxilliary fuel for largely inert waste streams.

- Slagging pyrolysis incinerator: The slagging pyrolysis incinerator (SPI) was originally developed to process municipal and industrial waste for the generation of low Btu content gas. The SPI system will require oxygen supply for low Btu gas production and to obtain slagging temperatures. A $220 \mathrm{lb} / \mathrm{h}$ slagging pyrolysis incinerator has been operated in Belgium for incinerating radioactive waste. The contaminated waste has been processed with good results.

Modification to this incinerator size would be necessary to meet the INEL's needs of $9 \mathrm{ton} / \mathrm{d}$. The off-gas emissions will be directly related to the waste characteristics. Demonstration, research, and development are needed in the area of the off-gas systems capability to handle excessive amounts of particulates, volatile compounds, chlorides, sulfides, and other such materials. 
- Energy optimizing furnace: The energy optimizing furnace (EOF) developed by KLSI is a hearth furnace using solid, liquid, or gas fuels and oxygen for melting metal or metal-oxide charge materials and producing vitrified inert solids. The preheating system coupled to the EOF could serve for pyrolys is of combustible solid waste. A small integrated EOF was started in Brazil in 1986 and is currently in operation. Demonstration of EOF is required in the areas of TRU processing, combustibles handling, and volatile metals. The main feature of the EOF melter is the low electrical requirement compared to plasma or Joule melters. As a consequence, an electrical furnace transformer is not required, and overall thermal efficiency for melting is increased because heat is directly obtained from the fuel instead of requiring electrical energy from a power station that is subject to its own fuel generating efficiency. Liquid oxygen required for the EOF combustion can be supplied from existent sources. This technology can be applied to TRU-bearing waste. The same provisions for evaluation and control of volatile metals and slag chemistry applies for the electrical furnaces'.

Controlled air: The destruction of infectious waste is most commonly accomplished with controlled air incineration. The designs, concepts, and theories are established and proven for burning infectious waste from hospitals. However, to meet INEL needs, research, development, and demonstration would be required to ensure the applicability to TRU waste. The off-gas emissions will be directly related to the waste constituents, and controlled combustion with oxygen is preferable to minimize off-gas. Although controlled air incinerators emit fewer particulates and $\mathrm{HCl}$, research, development, and demonstration tests will be necessary to ensure the radioactive and hazardous constituents can be handled.

Fluidized bed: Fluidized bed incineration is ideally suited for the destruction of solids, sludges, and liquids. The designs, concepts, and theories are fairly well-established and over 1000 fluidized-bed combustion units are in operation worldwide. Radioactive waste 
disposal has been studied at the Rocky Flats Plant using a fluidized-bed incinerator, and gas velocities must be high to maintain the bed for combustion. There are problems with fines carryover and high off-gas quantities unless feed is carefully controlled. It would probably be prudent to conduct some demonstration work to ensure the applicabllity to our waste and to abtain off-gas emission data for determining the necessary off-gas treatment requirements for the hazardous constituents.

- Infrared: Infrared incinerators have been demonstrated on a pilot-scale, and sludge and soil waste containing polychlorinated biphenyls and dioxin have been tested. To meet INEL needs, research, development, and demonstration would be required to ensure the applicability to TRU waste and off-gas requirements. In addition, it would have to be demonstrated that a unit could be built to meet our flow rate requirements.

- Pyrolysis: Pyrolytic systems are generally custom-designed to treat a specific waste type. The pyrolysis process can be carried out in a variety of furnace designs: rotary kiln, rotary hearth, roller hearth, etc. The size capacity of the furnaces range from 0.25 to 5 tons, depending on the furnace design. These sizes are in the range of our expected needs for the buried waste. Research, development, and demonstration tests would be necessary to ensure the system would apply to TRU waste and determine if there are any off-gas problems controlling acid gas emissions. The comments noted under rotary kiln also apply to pyrolysis.

- Off-gas: Numerous types of off-gas systems exist to handie a variety of off-gases and off-gas rates. One system that appears acceptable for both melting and incineration off-gases is developed by Pacific. Northwest Laboratories. This off-gas system is an established system that has been shown to handle radionuclides, particulates, and acids. currently, this off-gas system is being modified for use with the ISV project testing at the INEL. With multiple volatile metals, a 
multi-stage off-gas cleaning system is appropriate. The stages might consist of a first stage for volatile metal condensing, a second stage for metal fume recovery, and a third stage for actd gas correction, wet or dry recovery system, and sludge or dust collection to cold stabilization. Research and development and possible demonstration testing information could be obtained from the ISV tests for use with the melting and incineration system.

- Package/assay: The technology for packaging and assaying the waste is available. Nuclear waste of various forms (TRU and LLW) is packaged and assayed on a routine basis at nuclear facilities worldwide. The type of packaging is dependent on how the waste will be transported and what the requirements are at the destination site.

\subsubsection{Program Implementation Risks}

This section identifies major concerns ar sociated with program implementation assuming that Melting and Incineration system With LLW Presort is selected. Furthermore, risk of accomplishing the Program objectives is qualitatively characterized. Summary of results and major areas of concern are shown in Table IV-2-5. Program mission and objectives are given in Volume II.

2.2.2.1 Performance objectives. Basel ine cleanup standards for SDA pits and trenches at RWMC cannot be established unt 11 an ROD pursuant to the CERCLA process is reached. These standards will be derived ARARs under the CERCLA, standards set by risk assessments, and the State and local statutes. Since no specific requirements have been formally established at this time, it is assumed that the major ARARs for this system will be RCRA rules, the appropriate NRC regulations and guides, and DOE regulations and Orders.

In the Melting and Incineration System With LLW Presort, the major uncertainties listed below have been identified as areas of concern in the achievement of the performance objectives. 


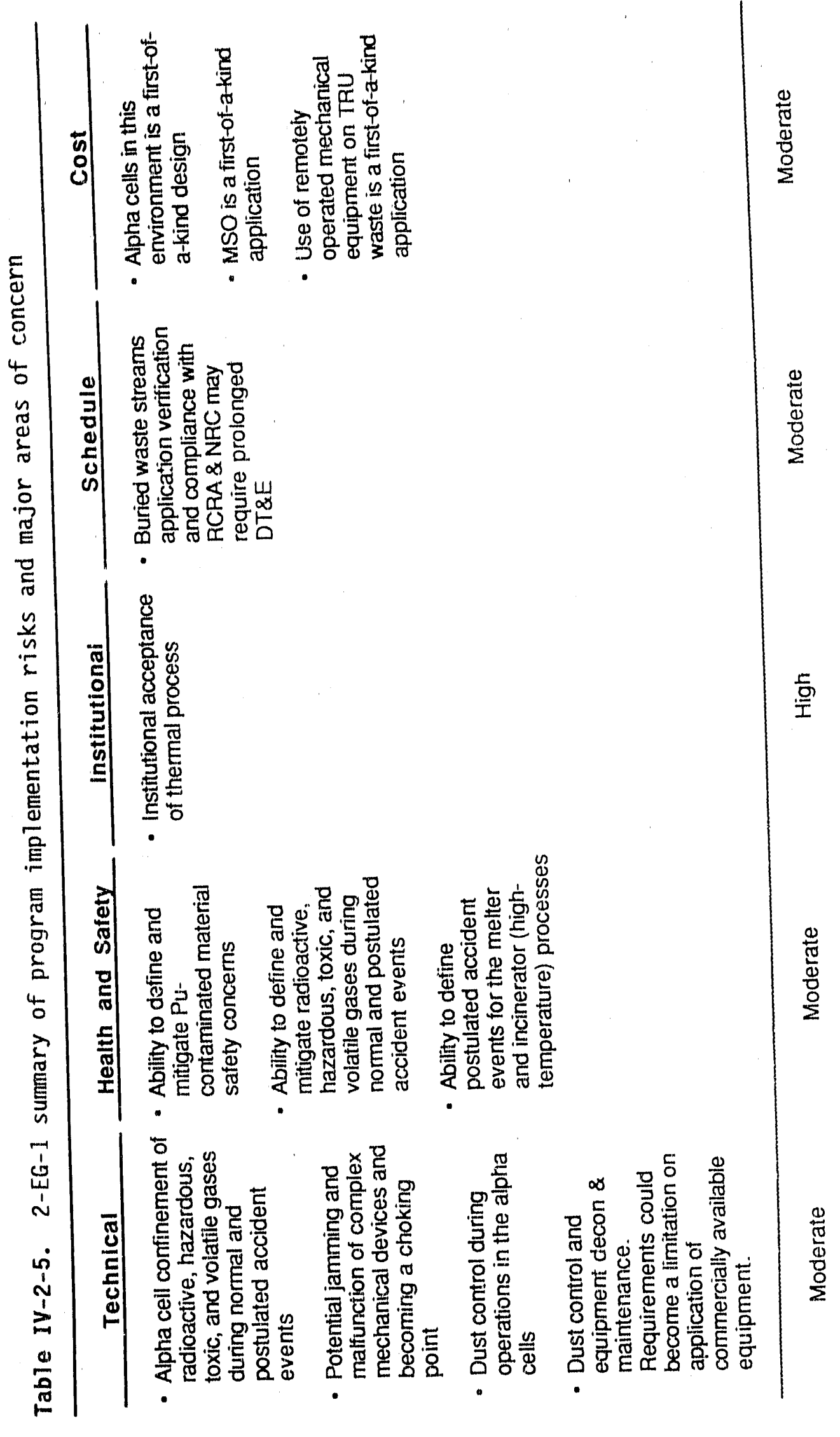




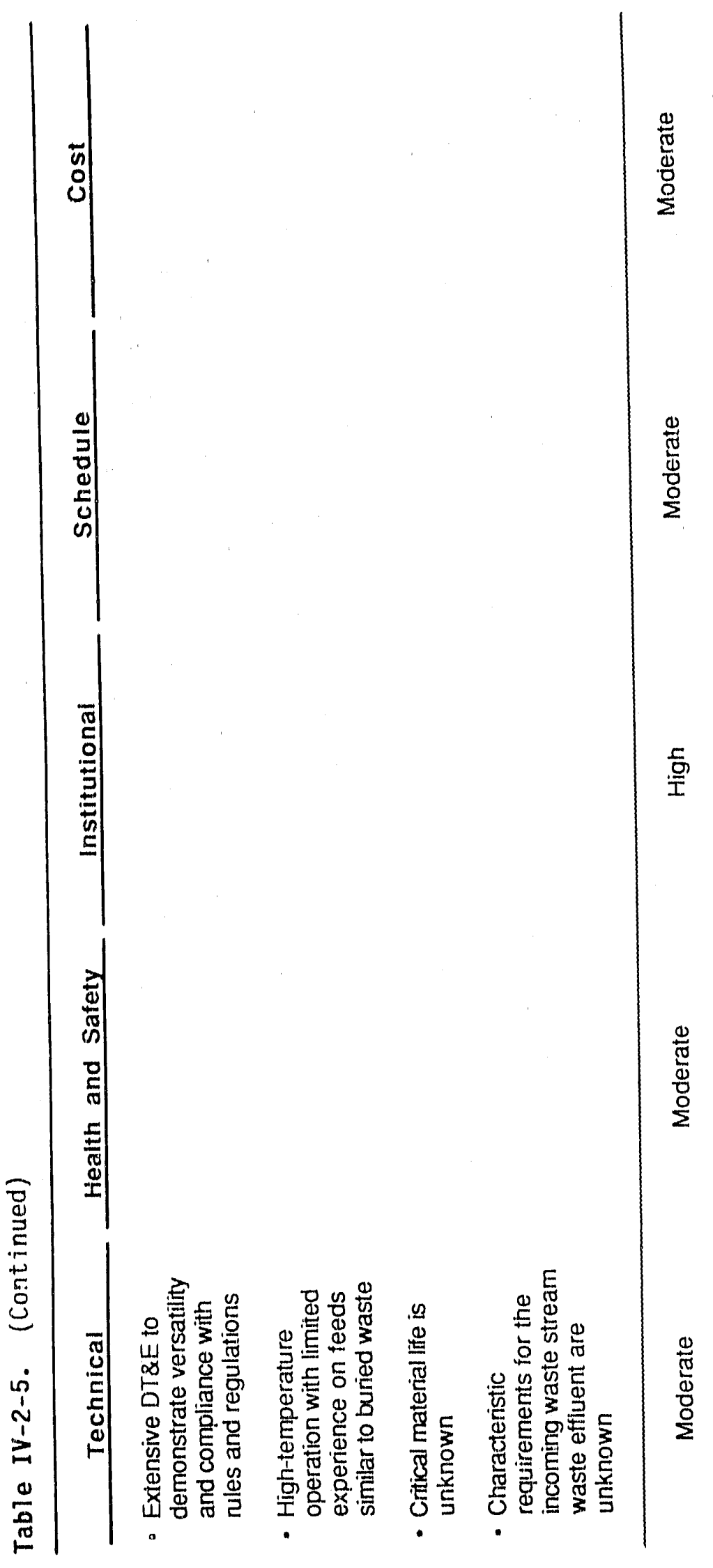




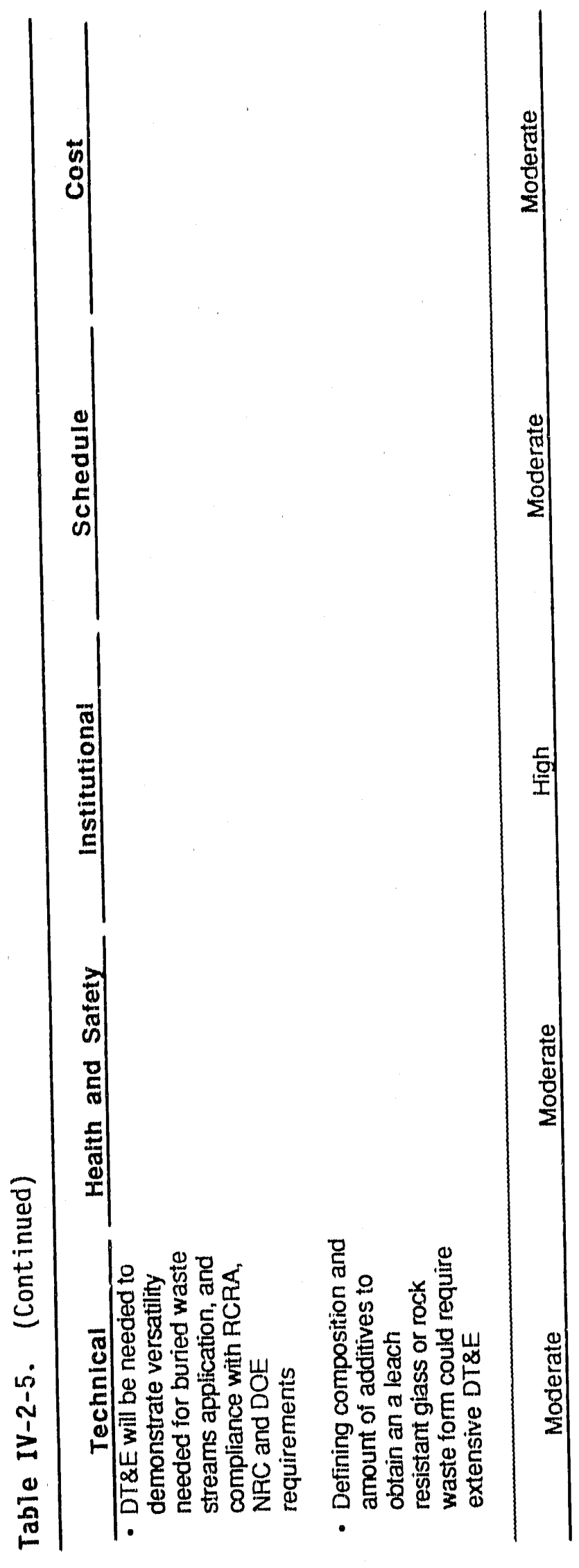

IV -52 
- Processing of the waste wit1 be conducted in several alpha cells. These cells will contain dust and any radioactive, hazardous, toxic, and volatile gases that may become atrborne during the waste handing and processing operations. Protection will have to be provided in normal as well as postulated accident events, such as a fire. Alpha cells, as used in the nuclear environment, typically have triple confinement barriers. A triple barrier is needed to ensure protection of worker, public health and safety, and the environment. The three parts typically consist of an operation area (which is usually contaminated), an isolation vestibule, and corridors where workers conduct the operations. Several of the waste handing operations will use technologies that are existing but will have to be adopted for use in an alpha cell environment. This requires remote operation and ease of decontamination for maintenance. These features make this system a first-of-a-kind facllity with many uncertainties regarding developing a cost effective design that provides the following:

Adequate confinement of radioactive, hazardous, toxic, and volattle gases during normal and postulated accident events.

Effictent operation of the complex mechanical equipment such as drum opening devices, sorting units, size reduction machines, manipulators, waste conveyors, and all related components that must be installed inside alpha cells. There is a concern regarding potential jamming and maloperation of these components. Any of these unit operations could be a potential choke point because of 1 imlted prior knowledge of waste streams and the high throughput requirements.

Additional technical concerns are (a) dust control during operations in the alpha cells could require very large and complex ventilation and filtration systems, (b) questionable operation of some of the equipment in a dusty environment, and (c) dust control in the alpha cell environment and equipment decontamination requirements before maintenance may become a limitation on application of commercially 
available equipment. DT\&E efforts could become more extensive than estimated.

- The incineration and melter unit operations are well understood and several technology options are available. DT\&E will be needed to demonstrate (a) application to TRU waste streams, and (b) compliance with RCRA, EPA emission standards, and NRC and DOE requirements.

- There are some uncertainties about the additives needed to produce a high integrity leach resistant vitrified waste form. More extensive DT\&E in this area will be needed.

Based on the above discussions, it is believed that the overall risk associated with achieving the performance objectives is moderate.

2.2.2.2 Health and Safety Objectives. The key health and safety objectives for the Buried Waste Program are to (a) identify the hazards of the remedial action operation, and (b) provide measures to eliminate, control, or mitigate identified hazards. In this system, major areas of uncertainty are:

- The ability to design for postulated accident events (such as fire, criticality, and unforeseen release of toxic/hazardous material) for the alpha cells and provide mitigation measures to satisfy the RCRA, NRC, and DOE requirements.

- The ability to design for postulated accident events (such as fire, criticality, and unforeseen release of toxic/hazardous material) for the melter and incinerator processes. Definition and mitigation of the normal and accident events for melter and incinerator could also become complex.

The uncertainties in regard to health and safety are largely due to the wide spectrum of incoming waste. DT\&E on characterization could provide a better confidence level. It is believed that use of remote handling equipment, and conducting operations inside alpha cells will enhance mitigation measures for a majority of the normal and postulated events. This approach reduces the risk 
associated with achieving the health and safety objectives. At this stage of the system modeling, it is believed that the overall risk is moderate.

2.2.2.3 Institutional objectives. A key institutional objective is to involve the public, as required by CERCLA and NEPA, in the process of selecting a remedial action for the Buried Waste Program. Public support of this system, which is a commercially proven but a very large thermal process, is believed to be low. Hence, it is believed that the risk associated with achieving the institutional objectives is high.

2.2.2.4 Schedule Objectives. The objective of the Buried Waste Program schedule is to reach key decision point 2 (i.e., approval for Title II start) by mid 1999. This is based on the assumptions that an ROD will be reached by the end of FY 2001. The schedule objectives for completion of the Buried Waste Program remedial action is by $F Y 2019$. The following major uncertainties in achieving these objectives have been identified.

- The alpha enclosure is a relatively complex first-of-a-kind structure and could be subject to prolonged DT\&E, design and construction. However, with advanced planning, uncertainties in achieving schedule objectives could be reduced.

- Use of remotely operated mechanical equipment for sorting, conveying, size reduction, etc. and handling of TRU waste is a first-of-a-kind application. Schedule uncertainties from prolonged DT\&E, design and construction are anticipated. Again, with advanced planning uncertainties in achieving schedule objectives could be reduced.

- Demonstration of melter and incinerator needed for buried waste streams application, and compliance with RCRA, NRC, and DOE requirements may require prolonged DT\&E.

- Demonstration of melter waste vitrification and compliance with EPA, NRC, and DOE standards may require prolonged DT\&E. 
Based on the above discussions, and an assumption that the Program implementation activities will start in FY 1992, the schedule risk is believed to be moderate.

2.2.2.5 Cost objective. Assessment of the cost objective is a qualitative characterization based on the uncertainties involved in defining a reasonably accurate cost estimate for the system. Some of the major uncertainties are presented below:

- The use of alpha cell in the given waste processing environment is a first-of-a-kind design subject to cost overruns from prolonged design development. Major areas of uncertainty are (a) the extent of design features needed for operating in a dusty TRU environment, (b) providing safety for postulated accident events (such as fire, criticality, unforeseen release of toxic/hazardous material), and (c) satisfying the RCRA, NRC, and DOE requirements. Currently the limited information available on waste characteristics contributes to these uncertainties.

- Use of remotely operated mechanical equipment for container opering, sorting, size reduction, and handling of TRU waste is a first-of-akind application. Cost uncertainties are anticipated until design, based on DT\&E, is well into maturity.

- Use of incinerator and melter for TRU-contaminated buried waste is a first-of-a-kind application. Cost uncertainties are anticipated until design, based on DT\&E, is well into maturity.

Based on the above discussions, the cost risk is believed to be moderate.

\subsubsection{Unit Operations Pro and Con Analysis}

The following discusses the pros and cons of each of the unit operations and the technology associated with that unit. The compatibility of the unit operations with other interfaces is also evaluated. The information was obtained from various sources and a list of references appears at the end of this section. 
2.2.3.1 On-Line Assay. An on-1ine assay is performed on the waste when it arrives at the waste facility. Sorting out the LLW from the TRU waste at the beginning of the process is not currently possible at production rates but development work is underway. The major impact is that a separate facility is needed to process the $L L W$, and this may or may not offset the savings from the reduction of TRU waste being processed. The total energy requirements for treating both the LLW and the TRU waste would probably be the same. The advantages to performing an on-line assay are reduction in the volume of waste that must be treated as TRU waste, reduction in the size and cost of TRU processing operation, and reduction in the cost for TRU waste disposal because the amount of waste processed as TRU waste is decreased. The disadvantages are (a) a separate facility is needed for LLW treatment, and (b) significant funding is needed to demonstrate methods for characterizing waste at TRU concentrations of $100 \mathrm{nCi} / \mathrm{g}$ with reasonable accuracy and at production capacity.

2.2.3.2 Open Containers and Bags. Given the proposed method of treating the waste, the containers must be opened in order to sort the waste. The waste containers are opened by conventional means, which are used in the municipal and nuclear waste industry and require the use of shredders, trammels, knives, and puncturing devices. These techniques are available and have been proven as feasible methods. The opening of containers ensures an accurate sort of the waste and incompatible waste can be identified before processing. However, the operation is time consuming and can result in contamination spread and increase maintenance needs.

2.2.3.3 Metal Sorting. The waste is segregated into two streams: metals and non-metals. This sorting is done manually with magnetic separation and with manipulators. The magnetic techniques considered for the buried waste include magnetic-head pulleys, suspended magnets, magnetic drums, and plate magnets.

All of these magnetic techniques and the use of manipulators should be compatible with removing the metal from the waste. They are all available commercially and have been proven in industry as feasible methods. Sorting the metal out for decontamination in a separate facility may or may not offset the savings from the reduction of TRU metal waste being processed. The advantages are segregation of the waste ensures cleaner and smoother operation of the melting and incineration processes, and process upsets from incompatible waste 
are prevented by separating the undesirable waste out before treatment. The disadvantages are segregating the waste is a time-consuming operation and increases chances of contamination leaks.

2.2.3.4 Combustible Sort. The combustible and noncombustible waste are separated from each other by visual inspection, density equipment, and aerodynamic equipment. Given the proposed method of treating the combustible waste by incineration and the resulting ash and noncombustible waste by a melting technique, this kind of sorting is a necessity. The advantages are

(a) segregating the waste ensures cleaner and smoother operation of the melting and incineration processes, (b) incinerating the combustible waste increases the capacity of the melter and provides better control of the uff-gases, which ensures a higher quality slag, and (c) preventing process upsets from incompatible waste by separating the undesirable waste out before treatment. The disadvantages are that segregating the waste is a time-consuming operation and there are increased chances of contamination leaks.

2.2.3.5 Size Reduction. Shredding the waste is probably the most efficient remote means of reducing the size of the waste for further processing. In addition to ensuring that the waste will meet the size restraints of the melter and/or incinerator, the respective thermal process will be more efficient if the waste is in a smaller form. Advantages of this method are (a) the waste is sized to meet the dimension restrictions of the melter/incinerator, (b) the melter/incinerator process is more efficient with smaller feeds and the waste is easier to manipulate into the melter/incinerator, and (c) shredders are available commercially, have a wide variety of application, and can be used done remotely. The disadvantages of this method are that shredding is an additional process step that is time-consuming and creates more chances for the spread of contamination.

2.2.3.6 Melting. Melting technologies handle a wide variety of wastes and produce a high integrity final waste form. Using a melting technology for treating the buried waste would be a very beneficial method given the wide variety of waste present. Several melting technologies exist. Melting technologies are capable of handling a wide variety of wastes (solid, liquid, combustible, noncombustible, metals, etc.) and of destroying organic materials and producing a high integrity final waste form. Heavy metals and radionuclides are dissolved into the final waste matrix. 
Metal is separated from slag, with TRU compounds partitioning to the slag phase. The volume of waste is reduced, assuming initial waste characteristics preclude the need for adding glass additives. Smaller off-gas rates minimize particulate entrainment and carryover, requiring smaller off-gas equipment. In addition, a high percentage of the remaining gases are combustible. The disadvantages include limited liquid and combustible application and high energy consumption (about $1 \mathrm{kWh} / \mathrm{kg}$ of waste). The technology is st 111 being developed and tested. Volatile metals, such as mercury, end up in the scrubber water and must be removed before water disposal. In addition, there are limitations on refractory linings requiring disposal of contaminated refractory lining an annual maintenance and deactivation schedule. With plasma systems, a relatively higher investment with water-cooled elements, refractory-lined vessels, and transformers is required.

2.2.3.7 Incineration. Several incineration methods exist, and incineration is widely used for treating organic wastes. Incineration systems for combustibles are relatively low cost compared to melting systems. The disadvantage is the lack of experience with TRU waste and alpha environment.

2.2.3.8 off-gas. Numerous types of off-gas systems exist to handle a variety of emissions and emission rates. An off-gas system is a necessity to meet the EPA air emission standard on hazardous and toxic emissions. The advantage of the off-gas system is they meet EPA emission regulations. The disadvantages are they have high capital costs and need development work for anticipated exhaust gas from hazardous waste destruction (volatile constituents, chlorides, sulfides, etc.).

2.2.3.9 Package/Assay. The packaging and assaying of nuclear waste is conducted on a routine basis at nuclear facilities worlduide. The type of packaging is dependent on the final waste form, how the waste will be transported, and the storage or burial requirements at the destination site. Assaying the waste is performed to determine the characteristics of the waste in order to meet the disposal site requirements. Segregating out any LLW at this point is also advantageous because it will reduce the overall cost of disposing the waste. (This assumes TRU waste disposal is more expensive.) 


\subsubsection{Unit Operations Lead-Time Estimates}

The lead-time required for DT\&E is estimated for each unit operation that may require DT\&E and is shown in Table IV-2-6. Lead time estimates are based on the assumptions given in Section 1.

\subsubsection{Rough Order of Magnitude Cost Estimates}

ROM costs are summarized in Table IV-2-7. The assumptions and qualifications used in the preparation of the ROM estimate for this system are given in Section 1. Additional assumptions are as follows:

- The process area will be contained in an alpha cell with one confinement barrier.

- The alpha cell process area will then be contained in a moderate hazard facility.

- The equipment list was generated by the project, based on the equipment necessary to support an existing (similar) INEL project (PREPP).

- This estimate does not include the infrastructure (utilities or site development).

- Office areas, restrooms, change rooms, decontamination areas, break rooms, conference rooms, etc. have not been included in this estimate.

- It was assumed that the demonstration of the melters and incinerators will be in an existing facility, modified to support the equipment.

- Facility 0ne, 2-EG-4, is capable of processing 57,040,101 1b of TRU waste $5 \mathrm{~d} / \mathrm{wk}, 70 \%$ plant availability, operational $240 \mathrm{~d} / \mathrm{yr}$. This is equivalent to $168 \mathrm{~d} / \mathrm{yr}$ or $4032 \mathrm{~h} / \mathrm{yr}$. 


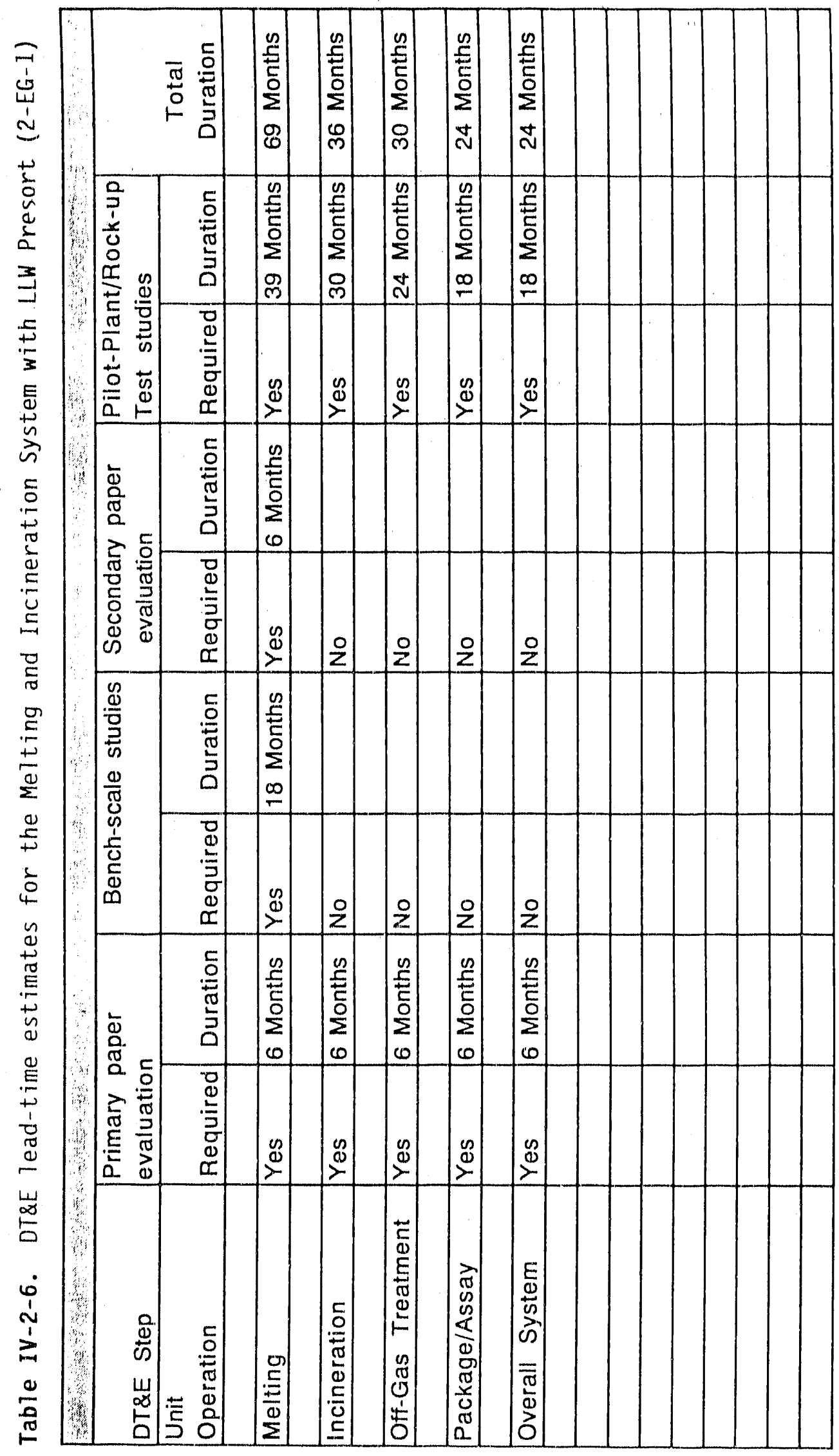


Table IV-2-7. Rough order of magnitude cost estimates (2-EG-1)

\begin{tabular}{|c|c|c|c|}
\hline $\begin{array}{l}\text { Cost } \\
\text { Code } \\
\end{array}$ & Cost ltems & $\begin{array}{c}\text { Normallzed } \\
\text { Cost } \\
(\$ \times 1000) \\
\end{array}$ & $\begin{array}{c}\text { Modifled } \\
\text { Cosi } \\
(\$ \times 1000) \\
\end{array}$ \\
\hline 1,0 & Studies and bench scale costs & & \\
\hline 1.1 & Manpower costs during research & $\$ 2,000$ & $\$ 2,000$ \\
\hline 1.2 & Equipment costs & $\$ 5,200$ & $\$ 5,200$ \\
\hline 1.3 & Installation costs & $\$ 0$ & $\$ 0$ \\
\hline \multirow[t]{2}{*}{1.4} & Contingency & $\$ 1,800$ & $\$ 1,800$ \\
\hline & Subtotal 1.0 & $\$ 9,000$ & $\$ 9,000$ \\
\hline 2.0 & Demonstration costs & & \\
\hline 2.1 & Manpower cost during construction & $\$ 4,000$ & $\$ 4,000$ \\
\hline 2.2 & Design cost $(30 \%$ of 2.5$)$ & $\$ 2,657$ & $\$ 2,657$ \\
\hline 2.3 & Inspectlon cost $(7 \%$ of 2.5$)$ & $\$ 62.0$ & $\$ 620$ \\
\hline 2.4 & Project administration (10\% of 2.5$)$ & $\$ 886$ & $\$ 886$ \\
\hline 2.5 & Construction cost & & \\
\hline 2.5 .1 & Building structure costs & $\$ 2,000$ & $\$ 2,000$ \\
\hline 2.5 .2 & Equlpment costs & $\$ 5,000$ & $\$ 5,000$ \\
\hline \multirow[t]{2}{*}{2.5 .3} & Indireot $(20.9 \%$ of 2.5$)$ & $\$ 1,855$ & $\$ 1,855$ \\
\hline & Subtota' of 2.5 & $\$ 8,855$ & $\$ 8,855$ \\
\hline 2.6 & Construotlon management costs $(27.8 \%$ of 2.5$)$ & $\$ 2,541$ & $\$ 2,541$ \\
\hline \multirow[t]{2}{*}{2.7} & Contingency & $\$ 4,890$ & $\$ 4,890$ \\
\hline & Subtotal 2.0 & $\$ 24,449$ & $\$ 24,449$ \\
\hline 3.0 & Production construction cosis & & \\
\hline 3.1 & Design cost $(30 \%$ of 3.4$)$ & $\$ 29,981$ & $\$ 29,981$ \\
\hline 3.2 & Inspection cost $(7 \%$ of 3.4$)$ & $\$ 6,995$ & $\$ 6,995$ \\
\hline 3.3 & Project administration $(10 \%$ of 3.4$)$ & $\$ 9,994$ & $\$ 9,994$ \\
\hline 3.4 & Construotion cost & & \\
\hline 3.4 .1 & Building structure costs & $\$ 68,000$ & $\$ 68,000$ \\
\hline 3.4 .2 & Equlpment costs & $\$ 11,000$ & $\$ 11,000$ \\
\hline \multirow[t]{2}{*}{3.4 .3} & Indirect $(20.9 \%$ of 3.4$)$ & $\$ 20,935$ & $\$ 20,935$ \\
\hline & Subtotal of 3.4 & $\$ 99,935$ & $\$ 99,935$ \\
\hline 3.5 & $\begin{array}{l}\text { Construction management costs and construction management } \\
\text { reserve }(26.5 \% \text { of } 3.4)\end{array}$ & $\$ 28,681$ & $\$ 28,681$ \\
\hline \multirow[t]{3}{*}{3.6} & Contingency $(25 \%$ of 3.1 through 3.5$)$ & $\$ 43,897$ & $\$ 43,897$ \\
\hline & Subtotal 3.0 & $\$ 219,483$ & $\$ 219,483$ \\
\hline & Total Capital Cost $(1.0,2.0$, and 3.0$)$ & $\$ 252,932$ & $\$ 252,932$ \\
\hline 4.0 & Annual operating and maintenance costs & & \\
\hline 4.1 & Operating costs & $\$ 2,500$ & $\$ 2,500$ \\
\hline 4.2 & Utillity cosis & $\$ 2,680$ & $\$ 2,680$ \\
\hline 4.3 & Material costs & $\$ 0$ & $\$ 0$ \\
\hline 4.4 & Maintenance costs & $\$ 500$ & $\$ 500$ \\
\hline \multirow[t]{2}{*}{4.5} & Contingency & $\$ 1,420$ & $\$ 1,420$ \\
\hline & Subtotal 4,0 & $\$ 7,100$ & $\$ 7,100$ \\
\hline TOTAL & 10 Years Operating and Maintenance Costs & $\$ 71,000$ & $\$ 71,000$ \\
\hline
\end{tabular}


- The operations costs are based on operating either facility for 24 $\mathrm{h} / \mathrm{d}, 5 \mathrm{~d} / \mathrm{wk}, 70 \% \mathrm{plant}$ avallability, operational $240 \mathrm{~d} / \mathrm{yr}$. This operating timie is equivalent to $4032 \mathrm{~h} / \mathrm{yr}$.

\subsubsection{System Evaluation Results}

The purpose of this section is to provide an overall evaluation on a system basis and to identify the major considerations (both advantages and disadvantages) resulting from the assessments in the previous sections. This includes an evaluation of the ability to integrate the various unit operations into a smooth, well-functioning system. Specific areas addressed include identification of system major considerations, a qualitative judgement rating of performance measurables as identified in the systems Engineering Management Plan (SEMP), a summary of DT\&E needs, and an overall recommendation for the system.

\subsubsection{Identification of Major System Considerations. Currentily a} wide variety of melting and incineration technologies exist and are in various stages of development and testing. Incineration is used in fossil power plants as well as in sanitary waste facilities; both have to address stringent emission requirements. In addition, melting techriques are employed in the mining and metals industry, much of which is applicable to processing hazardous waste. However, melting or incineration of mixed hazardous waste has only been performed on a limited scale.

The unknown characteristics of the waste stream feed stock in the rielter presents potential problems with the operation of the melter, such as consumption of the liner of the furnace. Certain types of input wastes may react with the furnace liner requiring repair, significant downtime, and radioactive exposure to maintenance personnel. In addition, the treatment of gaseous effluents resulting from melting or incinerating unknown materials may result in medium risk in designing the off-gas unit operation for a wide range of effluents. There is also a risk that the melter, incinerator, and off-gas unit operations could become a choke point for processing the waste.

The significant advantages for melting and incineration are the waste reduction and the conversion of the waste to a benign form. However, the 
significant disadvantages of melting and incineration are the potential for large volumes of off-gas and the need for secondary burners to further treat off-gas. The system requires signiffcant lead-time for research and development, and the cost estimates for this system are dependent on the input waste stream composition and conversion energy requirements.

\subsubsection{Performance Measurables Rating. Volume II tdentifies} performance measurables that should be used in the evaluation of the overall system. These measurables represent the top level of performance requirements that will be allocated and flowed down to appropriate elements of the system in subsequent phases of the program. Table IV-2-8 provides a judgment-based qualitative assessment of the Melting and Incineration with Post-LLW Sorting performance measurables.

\subsubsection{Summary of Demonstration, Testing, and Evaluation Needs}

The DT\&E needs for each unit operation and for the overall system are summarized in Table IV-2-4. This table provides a ready reference to DT\&E needs in the final system evaluation and for comparison purposes with other systems.

\subsection{Recommendation for the System}

The Melting and Incineration System with Pre-LLW Sorting System utilizes technologies to significantly reduce the volume of waste and thus minimize long-term storage requirements. The melting and incineration processes are sensitive to the input waste streams that may be minimized with further development. Both the melting and the incineration processes are undergoing testing and pilot plant operations, which should yield additional information in the system capability.

In consideration of the hazardous and toxic nature of the hydrocarbon and heavy metal contaminants involved and the long-term hazards of the TRU elements, the high temperature melting system approach represents a viable solution to the stabllization and minimization of these critical wastes. Further study and evaluation is essential concerning specific contaminant 


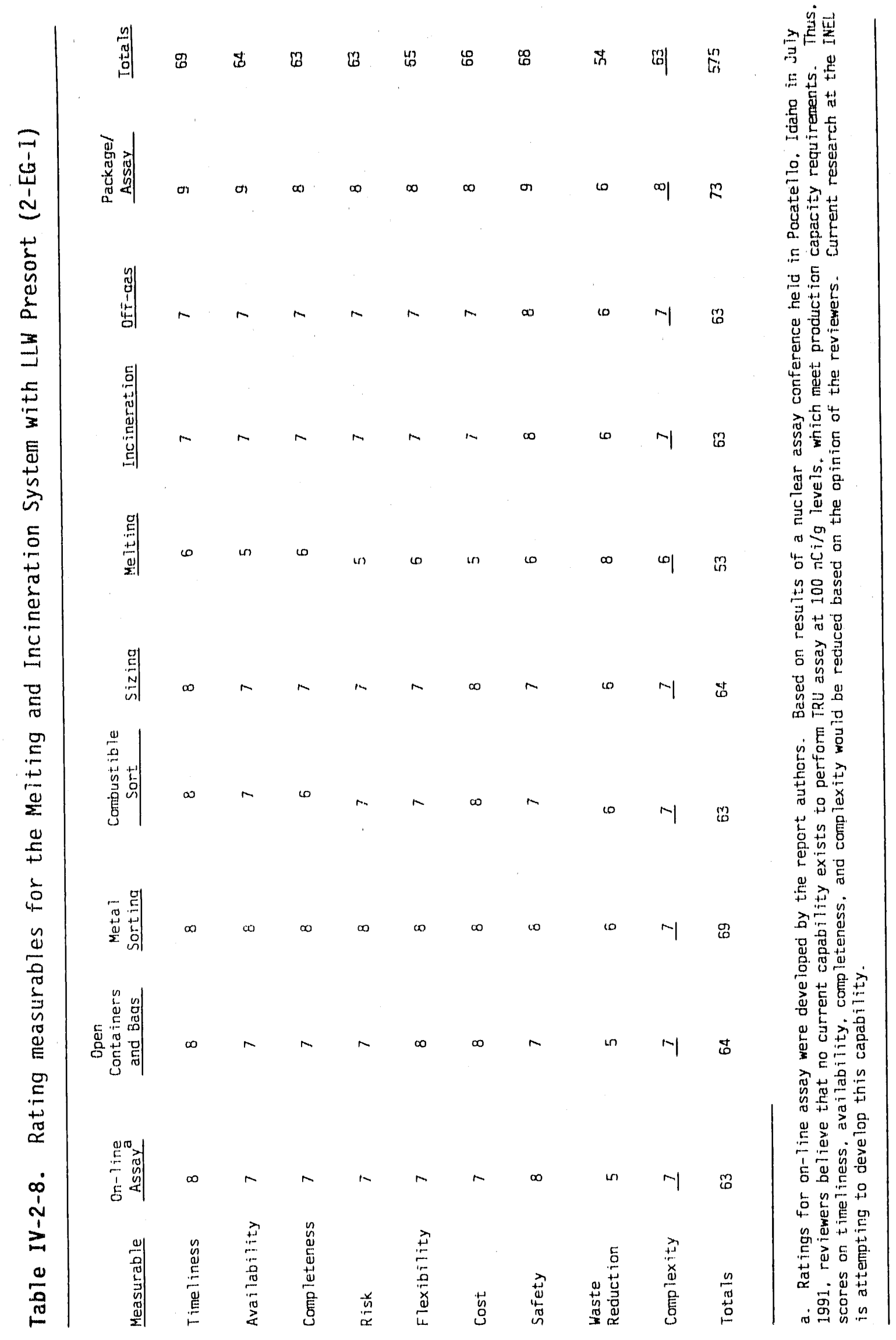


levels, quantities, and physical condition to determine which melting system or combination of systems will be most appropriate in consideration of site conditions, equipment avallability and costs, schedule restratnts, and actual hazard levels. Several issues that will require further development include the following:

- An analysis of queuing of the waste stream is required to determine capacities of components for unit operations

- The system as a whole will require fine tuning of all the selected technologies to produce the destred end results

- The integration of the process streams should be reviewed to ensure compatibility.

Consideration should be given to on-line sensors that monitor and report status and progress of waste stream processing. With the high temperature melting unit operation, the main effluent will be a vitreous slag phase of the constituent stable oxtdes. From a preliminary review of the projected feed materials, a secondary phase can be anticipated involving accumulation of unoxidized metals in the hearth or bottom of the melter during slag production. These metallics must be perfodically removed to maintain volume in the furnace.

Based on the compositional breakdown, a large proportion of the secondary phase on the melter hearth will be iron from the carbon steel. The iron accumulation may include some TRU contaminants if these elements are present as metal. Accordingly, this secondary phase metalltc waste, although greatly reduced in bulk volume, may present a long-term hazard. On the other hand, the metallics will tend to concentrate any of the TRU-contaminated metals, which may have an advantage for further processing. A pilot melter program is essential to enable evaluation of the quantity and composition of the secondary phase to be expected and to facilitate its disposition. 


\section{MELTING AND INCINERATION SYSTEM WITH LLW POSTSORT (2-EG-4)}

This section presents scoping F\&ORs, and the system assessmerit for a melting and incineration system (which is similar to that described in Section 2 with the exception that LLW is combined with TRU waste and is processed in the melters and incinerators). The process is represented by Figure IV-3-1. The overall requitrement of the process is to produce a final waste form that is leach resistant and has a high integrity structure of glass and rock.

A general process functional diagram (PFD), a scoping facility layout, and an estimate of the mass and energy balances around the process are contained within this scoping document.

The waste is comprised of soll, metals, and combustible and noncombustible waste. The soll is sorted out during the retrieval process and transported to the Solls Processing Subsystem for processing. The metals are sorted out at the processing facility and transported to the Metals

Decontamination/Sizing Subsystem for decontamination. After the metals are removed, the waste is sorted into noncombustible and combustible waste. The noncombustible waste is processed in the melter along with the TRU waste from the extt streams of the Soll and Metal Subsystem facilities. The combustible waste is incinerated and the resulting ash is processed in the melter with the other waste. The process off-gas streams are blended cogether and processed through an off-gas treatment system.

\subsection{Functional and Operational Requirements}

The F\&ORs are basically the same as that for the Melting and Incineration system with LLW Presort. When there are differences, they are described below:

- Process functional diagram: Figure IV-3-1 depicts the melting and incineration system. Unit operation descriptions are the same as 


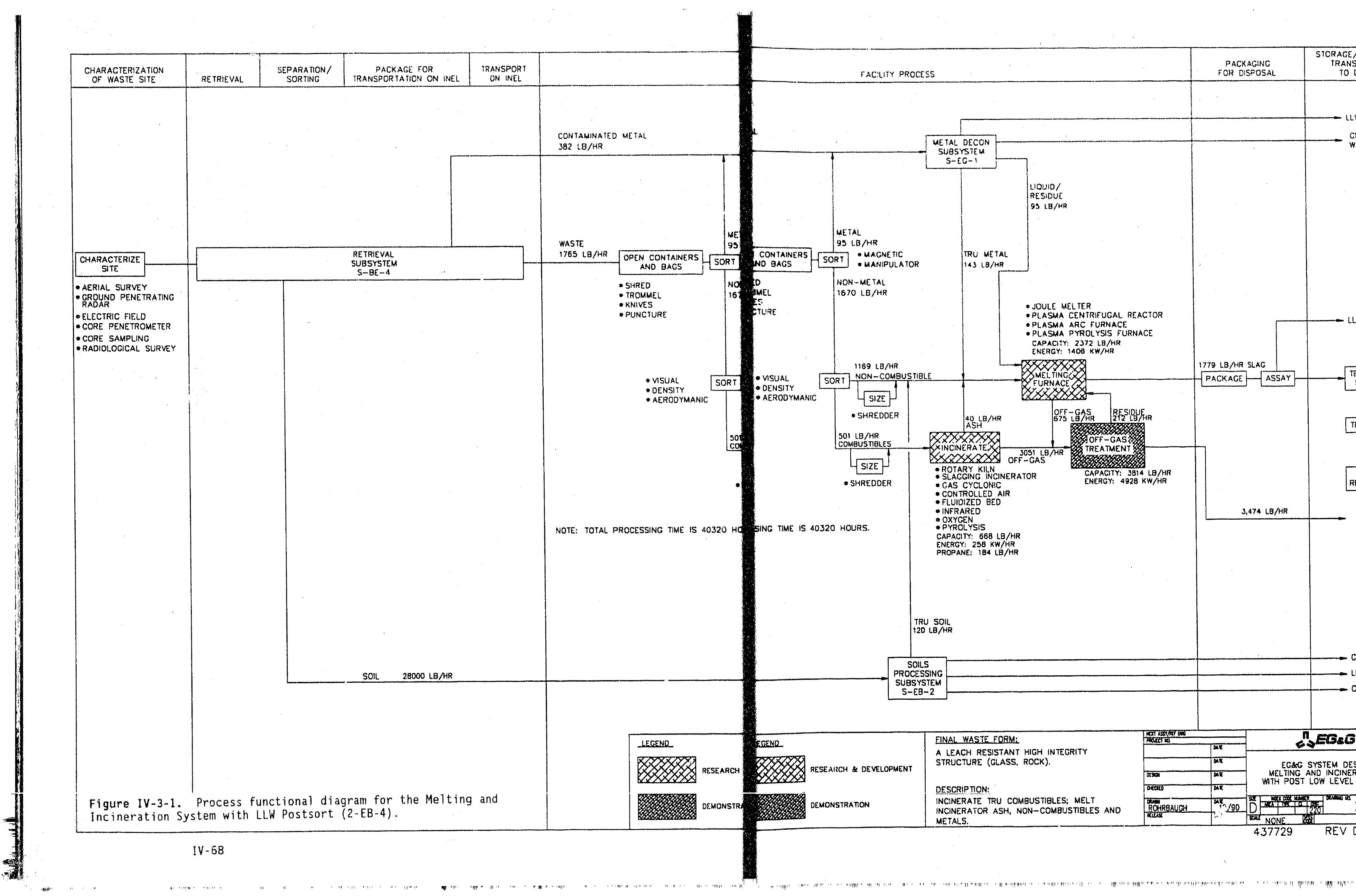


LLW METAL

CLEAN: WATER

LLW

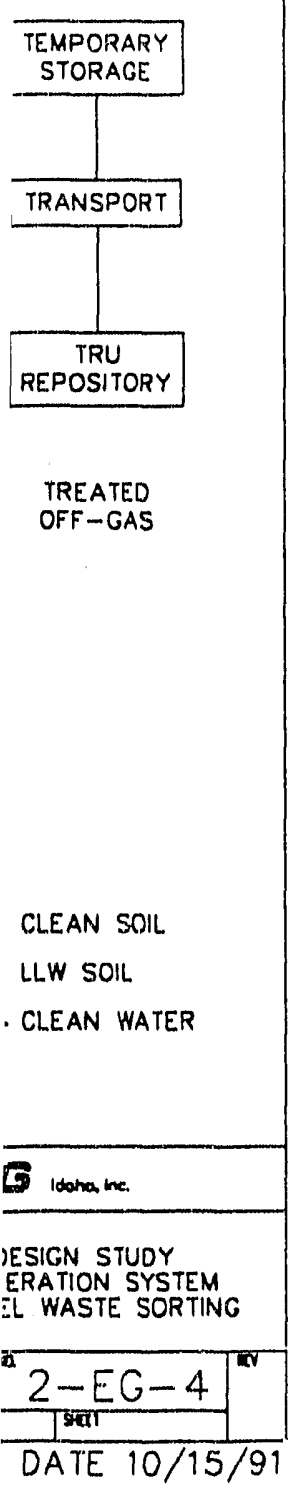


those of the Melting and Incineration System with LLW Presort with the exception that LLW is not sorted at the primary sort station.

- The mass and volume of input waste for this system are given in Table IV-3-1. Mass flow rates are shown in Figure IV-3-1.

- Unit operation capacities: The unit operation capacities are based on the mass of waste that must be processed over a 10-year period. The unit operation estimated capacities are listed in Table IV $-3-2$.

- Unit operation energy requirements:

Incinerator: The energy requirement, based on the necessary energy requirements to operate a rotary kiln incinerator with a mass flow rate of $375 \mathrm{lb} / \mathrm{d}$, is $138 \mathrm{kWh}$ of electric power plus $138 \mathrm{lb} / \mathrm{h}$ of propane consumption.

- Melting furnace: The energy requirement, based on the necessary energy requirements to operate an electric furnace with a mass flow rate of $1014 \mathrm{lb} / \mathrm{d}$, is approximately $1 \mathrm{MW}$.

Orf-gas system: These are very rough estimates for the off-gas system. Research and development is still studying the best treatment for the off-gas. The type of off-gas treatment chosen will determine more specifically what energy requirements are needed.

- Facility description: A scoping layout of the processing facility is shown in Figure IV-3-2.

- Performance requirements: The melting and incineration system is to perform at a level capable of processing approximately 17 ton of waste per day over a 10-year period. This consists of 5 ton/d 
Table IV-3-1. Mass and volume of waste by category ${ }^{a}$

\begin{tabular}{|c|c|c|c|}
\hline Category & $\begin{array}{l}\text { Weight } \\
(\mathrm{kg})\end{array}$ & $\begin{array}{l}\text { Weight } \\
\text { (1D) }\end{array}$ & $\begin{array}{l}\text { Volume } \\
\left(\mathrm{ft}^{3}\right) \\
\end{array}$ \\
\hline $\begin{array}{l}\text { Combustibles (sent to } \\
\text { incinerator) }\end{array}$ & $6,841,826$ & $15,083,490$ & $1,140,070$ \\
\hline Sludges (to plasma furnace) & $12,118,307$ & $26,716,020$ & 767,332 \\
\hline $\begin{array}{l}\text { Metals ( } 15 \% \text { that was } \\
\text { undetected and sent directly } \\
\text { to plasma furnace) }\end{array}$ & 951,858 & $2,098,466$ & 29,995 \\
\hline $\begin{array}{l}\text { TRU metals from metal } \\
\text { decontamination sub-system } \\
\text { ( } 30 \text { ib of metal for every } \\
100 \text { ib of metal sent to } \\
\text { metal decontamination } \\
\text { subsystem) }\end{array}$ & $1,618,159$ & $3,567,393$ & 50,993 \\
\hline $\begin{array}{l}\text { TRU residue from metal } \\
\text { decontamination sub-system } \\
\text { waste treatment ( } 20 \text { 1b for } \\
\text { every } 1001 \mathrm{~b} \text { of metal sent } \\
\text { to metal decontamination } \\
\text { subsystem) }\end{array}$ & $1,078,772$ & $2,378,261$ & Unknown \\
\hline $\begin{array}{l}\text { Concrete, soil }(85 \% \\
\text { concrete, } 15 \% \text { soil) }\end{array}$ & $2,281,468$ & $5,029,724$ & 106,263 \\
\hline $\begin{array}{l}\text { TRU soil from the soil } \\
\text { processing subsystem ( } 1 \% \text { of } \\
\text { the TRU soil processed at } \\
\text { the soil processing } \\
\text { subsystem) }\end{array}$ & 512,612 & $1,130,104$ & 9,718 \\
\hline Glass, filters, insulation & 402,895 & 888,222 & 47,668 \\
\hline $\begin{array}{l}\text { Miscellaneous: } \\
\quad \text { Plastic, resin, } \mathrm{Li}, \mathrm{Hg}\end{array}$ & 579,935 & $1,278,525$ & 63,944 \\
\hline Total & $26,385,832$ & $58,170,205$ & $2,215,983+$ \\
\hline
\end{tabular}

a. The initial weight and volume of the waste were obtained from the unpublished research results of C. R. Edinborough, EG\&G Idaho, Inc., Idaho Falls, Idaho, August 15, 1990. 
Table IV-3-2. Unit estimated capabilities

Equipment

Incinerator (rotary kiln)

Melting furnace (plasma pyrolysis furnace)

Plasma torch power

Plasma torch cooling water

Off-gas system (Pacific Northwest Laboratories)

Off-gas cooling water
Capacity

$375 \mathrm{lb} / \mathrm{h}\left(679 \mathrm{ft}^{3}\right) \odot 18000 \mathrm{~F}$

$1,014 \mathrm{lb} / \mathrm{h} \quad\left(64 \mathrm{ft}^{3}\right) \odot 36320 \mathrm{~F}$

$1 \mathrm{MW}$ (with $228 \mathrm{~Tb} / \mathrm{air}$ )

$25,000 \mathrm{Ib} / \mathrm{h}$

$2,641 \mathrm{lb} / \mathrm{h}$ o 1800 to $20000 \mathrm{~F}$

$55,017 \mathrm{lb} / \mathrm{h}$ 


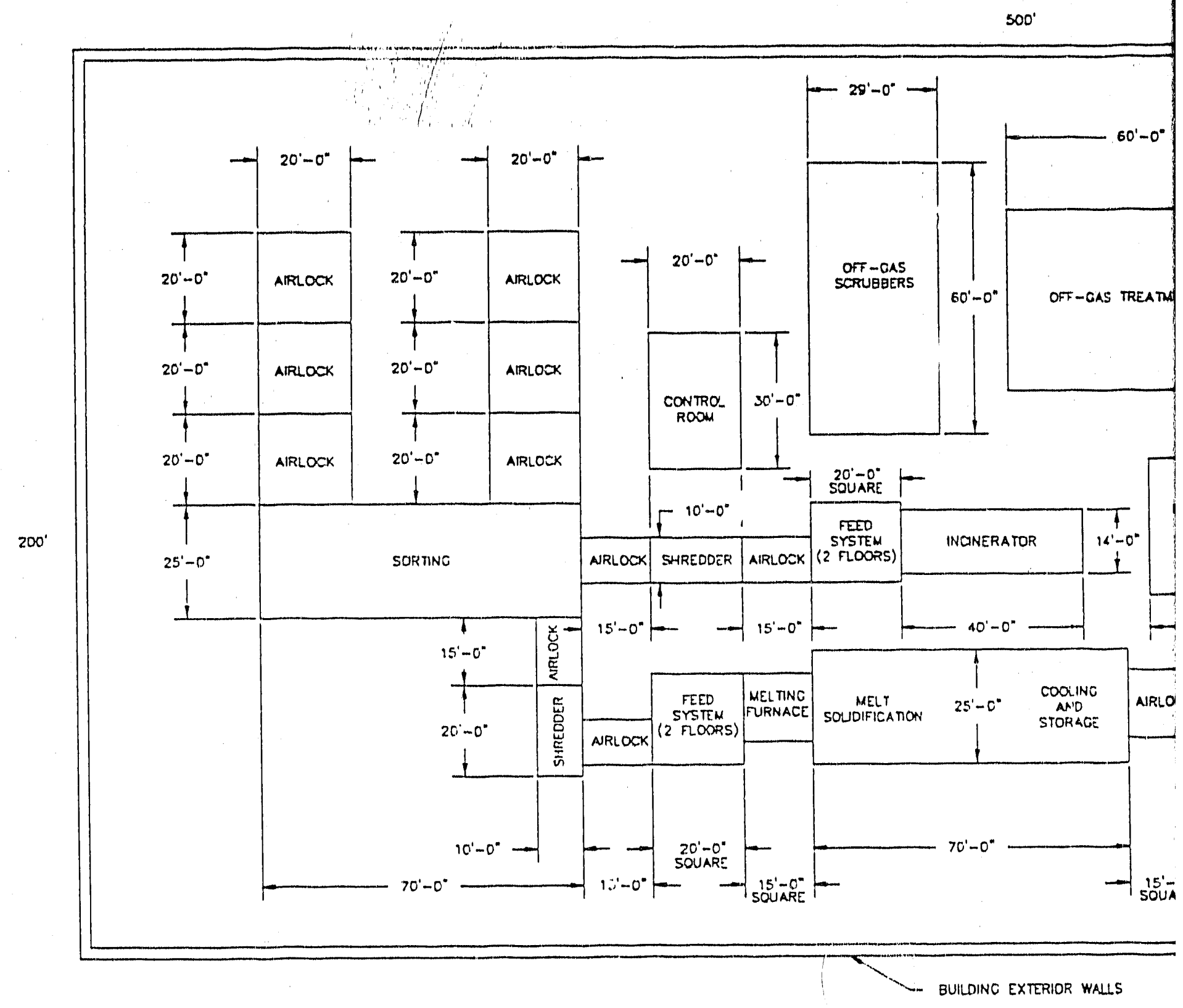

Figure IV-3-2. Layout of the processing facility for the Melting and Incineration System with LLW Post: IV -72 
of combustible waste processed in an incinerator, and 12 ton/d of noncombustible waste including the incinerator ash from the combustible waste. The off-gas system is to have the capacity to handle $2641 \mathrm{lb} / \mathrm{h}$ of off-gas. This includes the gas generated from both the melting furnace and the incinerator.

\subsection{System Assessment}

The system assessment for the Melting and Incineration System with LLW Postsort is the same as the Melting and Incineration system with LLW Presort with the exceptions discussed below:

- Program implementation risks: In general, program implementation risks for the Melting and Incineration System with LLW Postsort in general are less than the Melting and Incineration System with LLW Presort. This is largely because (a) in the Melting and Incineration System with LLW Postsort, LLW does not have to be assayed in the front end of the process, and (b) the system is less complex because it does not have a separate processing facility for $L L W$ treatment. The overall implementation risks for the Melting and Incineration system with LLW Postsort are shown in Table IV-3-3.

- ROM cost estimates: ROM costs are summarized in Table IV-3-4. 


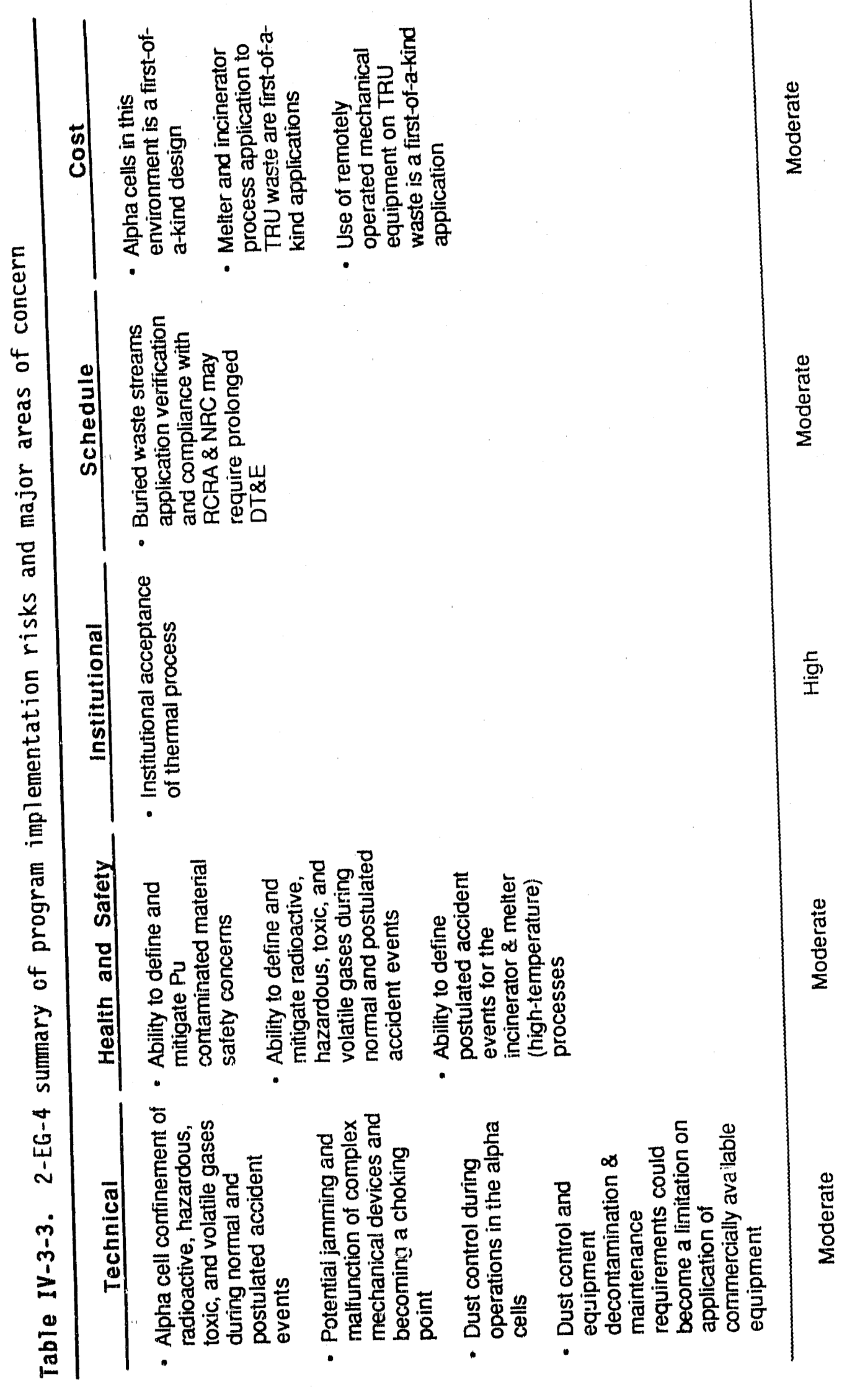




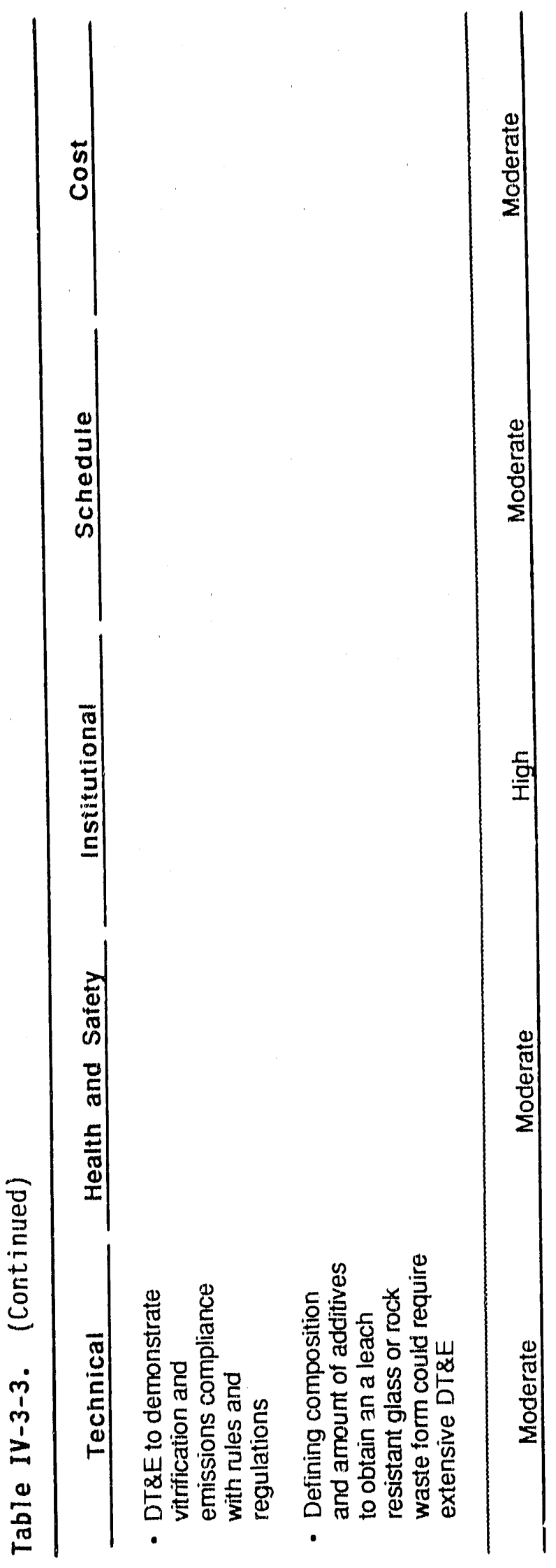


Table IV-3-4. Rough order of magnitude cost estimates (2-EG-4)

\begin{tabular}{|c|c|c|c|}
\hline $\begin{array}{l}\text { Cost } \\
\text { Code }\end{array}$ & Cost Ilemis & $\begin{array}{c}\text { Normallzed } \\
\text { Cost } \\
(\$ \times+000) \\
\end{array}$ & $\begin{array}{c}\text { Modiflod } \\
\text { Cost } \\
(\$ \times 1000) \\
\end{array}$ \\
\hline 1.0 & Studios and benoh sualo oosts & & \\
\hline 1.1 & Manpower costs during resoarch & $\$ 2,000$ & $\$ 2,000$ \\
\hline 1.2 & Equipment costs & $\$ 4,000$ & $\$ 4,000$ \\
\hline 1,3 & Installation costs & $\$ 1,200$ & $\$ 1,200$ \\
\hline \multirow[t]{2}{*}{1.4} & Contingenoy & $\$ 1,800$ & $\$ 1,800$ \\
\hline & Subtotal 1.0 & $\$ 9,000$ & $\$ 9,000$ \\
\hline 2.0 & Demonstratlon costs & & \\
\hline 2.1 & Manpower cost during construotion & $\$ 4,000$ & $\$ 4,000$ \\
\hline 2.2 & Deslgri cost $(30 \%$ of 2.5$)$ & $\$ 2,657$ & $\$ 2,657$ \\
\hline 2.3 & Inspoction cost $(7 \%$ of 2.5$)$ & $\$ 620$ & $\$ 620$ \\
\hline 2.4 & Projoot adminlstration $(10 \%$ of 2.5$)$ & $\$ 886$ & $\$ 886$ \\
\hline 2.5 & Construation oost & & \\
\hline 2.5 .1 & Bullding struclure costs & $\$ 2,000$ & $\$ 2,000$ \\
\hline 2.5 .2 & Equipment costs & $\$ 5,000$ & $\$ 5,000$ \\
\hline \multirow[t]{2}{*}{2.5 .3} & Indirect $(20,9 \%$ of 2.5$)$ & $\$ 1,855$ & $\$ 1,855$ \\
\hline & Subtotal of 2.5 & $\$ 8,855$ & $\$ 8,855$ \\
\hline 2.6 & Construction managument costs $(27.8 \%$ of 2.5$)$ & $\$ 2,541$ & $\$ 2,541$ \\
\hline \multirow[t]{2}{*}{2.7} & Contlingency & $\$ 4,890$ & $\$ 4,890$ \\
\hline & Subtotal 2.0 & $\$ 24,449$ & $\$ 24,449$ \\
\hline 3,0 & Production conetruction costs & & \\
\hline 3.1 & 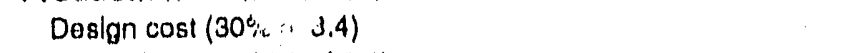 & $\$ 36,432$ & $\$ 36,432$ \\
\hline 3.2 & Inspection cost $(7 \%$ of 3.4$)$ & $\$ 8,501$ & $\$ 8,501$ \\
\hline 3.3 & Projent adininistration $(10 \%$ of 3.4$)$ & $\$ 12,144$ & $\$ 12,144$ \\
\hline 3.4 & Construation cost & & \\
\hline 3.4 .1 & Bullding structure costs & $\$ 85,000$ & $\$ 85,000$ \\
\hline 3.4 .2 & Equlpment costs & $\$ 11,000$ & $\$ 11,000$ \\
\hline \multirow[t]{2}{*}{3.4 .3} & Indireot $(20.9 \%$ of 3.4$)$ & $\$ 25.440$ & $\$ 25,440$ \\
\hline & Subtotal of 3.4 & $\$ 121,440$ & $\$ 121,440$ \\
\hline 3.5 & $\begin{array}{l}\text { Constructlon management costs and constructlon managenient } \\
\text { reserve }(26.5 \% \text { of } 3.4)\end{array}$ & $\$ 34,853$ & $\$ 34,853$ \\
\hline \multirow[t]{3}{*}{3.6} & Contingency $(25 \%$ of 3.1 through 3.5$)$ & $\$ 53,343$ & $\$ 53,343$ \\
\hline & Subtotal 3.0 & $\$ 266,713$ & $\$ 266,713$ \\
\hline & Total Capltal Cost $(1.0,2.0$, and 3.0$)$ & $\$ 300,162$ & $\$ 300,162$ \\
\hline 4.0 & Annual operaling and maintonanoe costs & & \\
\hline 4.1 & Operatlng costs & $\$ 2,500$ & $\$ 2,500$ \\
\hline 4.2 & Utllity costs & $\$ 710$ & $\$ 710$ \\
\hline 4.3 & Material costs & $\$ 2,000$ & $\$ 2,000$ \\
\hline 4.4 & Malntenance costo & $\$ 500$ & $\$ 500$ \\
\hline \multirow[t]{2}{*}{4.5} & Contingency & $\$ 1,428$ & $\$ 1,428$ \\
\hline & Subtotal 4.0 & $\$ 7,138$ & $\$ 7,138$ \\
\hline TOTAL & 10 Years Operating and Malntenance Costs & $\$ 71,375$ & $\$ 71,375$ \\
\hline
\end{tabular}




\section{IN SITU VITRIFICATION AND RETRIEVAL. PROCESSING SYSTEM (2-EB-3)}

This section describes the functional and operational requirements (F\&OR) of the In Situ Vitriftcation (ISV) Retrieval Processing System the transurantc (TRU) waste in RWMC.

\subsection{Functional. and Operational. Requirements}

\subsubsection{System Description}

Vitrification is a thermal treatment process that converts mixed waste into a chemically inert, stable glass and crystalline product. The ISV process is used in a place that has undisturbed burled waste. The final destination for the remediated waste is offsite for this system. Therefore, the vitrifted mass is excavated from the site and broken up for packaging and disposal. The fines created from the fracturing can become mobile in a final disposal site; they are then transported from the site to a thermal process facility within the INEL Site boundaries and vitrifled again into a molten magma. The magma is quenched to form a larger size of vitrified waste that is not mobile, packaged in containers, and assayed for disposal.

ISV uses electrical currents to heat the waste up to $3600^{\circ} \mathrm{F}$, forming and maintaining a molten glass magma that progresses outward and downward to melt a11 of the waste into a vitrified state. Metals, soils, and other wastes fuse into a molten magma of glass, while organics are destroyed by anaerobic pyrolysis. Ex situ vitrification is one of several technologies that could be employed to immobilize the fines generated from fracturing the ISV hardened glass. A joule heater uses electrodes to heat an initial mass of clean material into a molten mass of glass. The fines are fed into the refractory lined cnamber along with vitrification atds to ensure complete vitrification. In both vitrification technologies, eddy currents mix the molten mass, that effectively dilutes and immobilizes radioactive elements into the glass-like product. The molten magma cools and hardens to a high integrity material with 
very low leachability (reportedly less than glass or grantte). The magma is very resistant to weather degradation and is compared to the natural occurring volcanic glass and obsidian. The ISV mass cools by heat transfer into the surrounding solls and to the surface, while the ex situ process uses a quench tank to cool the magma. Processed off-gas, in both cases, is collected and treated by off-gas hoods and treatment systems.

4.1.1.1 Site Characterization. Site characterization includes further research of the documentation of the waste received at RWMC. In addition, all new characterization of the waste inside the pits or trenches is to be accomplished by nonintrusive geotechnical methods to minimize the risk of exposure to hazardous and radioactive material, as well as from explosion or fire. It is assumed that these methods can adequately identify the major concentrations of metals and volds in the pits and trenches to allow for ISV preparation of potentially incompatible areas.

4.1.1.2 In Situ Vitrification Preparation. Clean overburden soil will be required to provide suffictent molten glass mass to fill in voids without loss of continuity, increase the capture of contaminants, and provide sufficient thermal mass to melt and vitrify high concentrations of metal successfully.

Only one pit is expected to require the excavation of a spectal waste, as identified during the site characterization, that cannot be vitrifted. The excavation enclosure facility will be the same structure used to provide double containment over the ISV process, using the same off-gas treatment system as for the ISV.

4.1.1.3 In Situ Vitrification. ISV of all of the volume of RWMC mixed wastes must be complete in five years to allow the molten glass enough time to cool sufficientiy to excavate and fracture the material. One vitriffed waste site this size is estimated to take a year to cool, with heat transferring to the surface and to the soll surrounding the melt. A molten mass surrounded on two or four sides by other molten masses has a much reduced heat transfer 
surface, therefore will take longer to cool. A heat transfer analysis is required to confirm the assumed cooling time required.

4.1.1.4 Excavate and Fracture. The excavation and fracture of the hardened ISV waste will involve the use of as many excavation and mining pleces of equipment as required to reduce the stze of the glass into packable sizes. A vartety of sizes is required to obtain the high density packing desired for volume inimization of disposed waste. Battelle experience in reducing ISV glass to 1 - ft stzes resulted in very 11 ttle generation of fines. It is assumed, however, that some crushing or pulverization will be required to obtain the smaller pleces to fill in the volds between the larger pieces during packaging.

4.1.1.5 Joule Heater. A large joule heater unit will be used to melt the firies resulting from the fracture and excavation of the vitriffed waste. Because of the lower operating temperatures required, for the sake of extending the 1 if of of the refractory, additives are usually required with this type of matertal to achieve a uniform melted product.

4.1.1.6 Assay of Vitrifted Waste. A final assay is performed to separate TRU waste from low-level waste (LLW). The proportion of remediated TRU and LLW packaged for disposal is assumed to be the same as the ratio of untreated waste.

4.1.1.7 Off-gas Treatment systems. The off-gas treatment systems serving each of the ISV operations and joule heaters are assumed to be very simllar in design and function. The treatment system cools, scrubs, sorbs organics, and fllters the gases collected before releasing to the atmosphere. System components typically include a gas cooler, wet scrubber, off-gas to glycol heat exchanger, process solution scrub tank, scrub solution pump, condenser, mist eliminators, heater and charcoal filter, blower, and HEPA filter bank.

Secondary waste streams from the off-gas treatmerit systems, the similarly designed ISV enclosure off-gas treatment system, include spent 
scrubbing solution from a slurry recycling system, spent resin from the slurry recycling system, spent HEPA filters, and activated carbon filter regenerant. All solid secondary wastes are vitrified as they are generated, either in the ISV operations or the joule heater. Few contaminants are expected to be generated from the enclosure off-gas treatment system and are, therefore, ignored at this level of system definition.

\subsubsection{System Boundaries}

The system boundary for the ISV/Retrieval/Me1t Fines remediation of RWMC includes all of the RWMC site, any additional space adjacent to the site required for equipment and material staging and decontamination, and a process facility located on the INEL Site. The low-level and TRU waste will be in situ vitrified in Trenches 1-10, and Pits 1-6, 9, and 10. The hardened waste form will be excavated and fractured for high density packaging of large pieces for offsite disposal. The fines generated from the operation are transported to the process facility where larger vitrified waste pieces are formed, packaged, and assayed for offsite disposal. With the exception of special wastes that cannot be in situ vitrified, no primary wastes will leave the site, only remediated waste fines. The remediation and handling of special wastes is not addressed by this design study. All off-gases and dust released during the remediation processes are captured and treated on site. Secondary waste generated from the off-gas treatment systems include spent filters and spent scrub solution. The secondary waste streams are vitrified along with the primary waste as they are generated.

4.1.2.1 System Specific Assumptions. The following are system-specific assumptions for ISV and Retrieval Process System (2-EB-3):

- The addition of $4 \mathrm{ft}$ of clean overburden soil is assumed to be required over $75 \%$ of the total pit and trench surface area to provide sufficient molten glass mass in order to fill voids without loss of continuity, increase the capture of contaminants, and provide sufficient thermal mass to melt and vitrify high concentrations of metal successfully. 
- Only one pit is expected to require the excavation of a special waste, as identified during the site characterization, that cannot be vitrified. The excavation enclosure facility will be the same structure used to provide double containment over the ISV process, using the same off-gas treatment system as for the ISV.

- An average, suitable ISV surface area (ce11) size for remediating the waste at RWMC is $30 \times 30 \mathrm{ft}$. The average depth of trench and pit waste and contaminated soil is $19 \mathrm{ft}$ to the basalt. An additional $4 \mathrm{ft}$ of clean overburden soil brings the required ISV depth to $23 \mathrm{ft}$. ISV tests are being conducted to achieve $20-30-\mathrm{ft}$ depths. The $23-\mathrm{ft}$ depth is assumed to be possible; therefore, the ISV process requires a capacity of $20,700 \mathrm{ft}^{3}$ per cell.

- An ISV rate of $4 \mathrm{ton} / \mathrm{h}$, assuming a mixed waste density of $100 \mathrm{lb} / \mathrm{ft}^{3}$ will require 11 days of $24 \mathrm{~h}$ of vitrification (260 h). It is reported that the ISV equipment can be moved and set up for the next process in $16 \mathrm{~h}$; however, two days are allowed for a total 13-day ISV cycle. This estimate is ambitious considering the secondary enclosure must also be moved. Assuming $70 \%$ availability for 240 working days per year, eight ISV processes are required to operate simultaneously to complete the ISV treatment within five years.

- ISV operations must be complete in five years to allow the molten glass enough time to cool sufficiently to excavate and fracture the material. One vitrified waste site this size is estimated to take one year to cool, with heat transferring to the surface and to the soil surrounding the melt. A molten mass surrounded on two or four sides by other molten masses has a much rediced heat transfer surface, and therefore, could take significantly longer to cool. A heat transfer analys is is required to confirm the assumed cooling time required. 
- An oversized hood (55 ft in diameter) covers the waste area being vitrified to collect ISV off-gases for treatment and safe emission to the atmosphere.

- ISV energy consumption is estimated at $800 \mathrm{kWh}$ per ton of material vitrified.

- Although Battelle experience in reducing ISV glass to $1-\mathrm{ft}$ sizes resulted in very little generation of fines, it is assumed that some crushing or pulverization will be required to obtain smaller pieces to fill the voids between the larger pieces during packaging. An estimated $15 \%$ by weight of the ISV glass is assumed to be converted into fines during this operation.

- Large, industrial joule heaters have been constructed to process $500 \mathrm{ton} / \mathrm{d}$ of glass. A $150 \mathrm{ton} / \mathrm{d}$ unit should meet the needs of this system. The unit is derated $90 \%$ to process the ISV fines, resulting in a capacity of 135 ton/d. Assuming $24-h$ days are worked per week, 240 days per year, and a joule heater availability of $70 \%$, one unit is required to vitrify the fines into an immobile waste form (glass) over five years (actual process time using the noted operating schedule is 4.6 years). Approximately $800 \mathrm{kWh}$ per ton of glass is required to treat the fines, and an idle power use of $30 \%$ of the operating power is required to keep the molten glass bed in the joule heaters hot over the weekends. Ignoring the ramp-up of power required to restart the process, the energy consumption for the heater is 23 GWh per year, with a total consumption of 106 GWh over the 4.6 years of operation.

- The proportion of remediated TRU waste and LLW packaged for disposal is assumed to be the same as the volumetric ratio of untreated waste. 
- Current ISV off-gas treatment capacity is $3700 \mathrm{scfm}\left(104 \mathrm{~m}^{3} / \mathrm{min}\right)$ using about an $80 \%$ load on a $200 \mathrm{hp}(149 \mathrm{~kW})$ blower, although a larger capacity will be established during design.

\subsubsection{Process Functional Diagram}

A functional diagram for the in situ vitrification system is presented in Figure IV-4-1. Mass flows are noted for each process flow box, "unit operation." Capacities noted are based on current working technologies, although some areas may require additional testing or operating experience before they can be referred to as "proven" technologies. Energy requirements are also identified on the diagram.

\subsubsection{Facility Description}

Secondary containment for the eight operating ISV off-gas collection hoods is required and is shown in Figure IV-4-2. To estimate the area required to enclose eight operating ISV sites, the off-gas collection hood diameter of $55 \mathrm{ft}$ must be considered, as well as accounting for sequential 30-fi vitrification sites. These constraints dictate a minimum installation of an operating ISV at every third site in a line. Allowing for $15-\mathrm{ft}$ clearance around the hoods, an enclosure area of $85 \times 760 \mathrm{ft}\left(64,600 \mathrm{ft}^{2}\right)$ is required. Figure IV $-4-3$ is the ISV secondary enclosure section. Development of facility design requirements and experimentation of various locations may result in a larger facility. However, for cost effectiveness the construction should be designed for portability; the enclosure could then be relocated along with the ISV sites as the remediation progresses. The enclosure must be maintained at a negative pressure compared to the atmosphere, while capturing any gases that escape from the hoods. All of the air moving through the enclosure is treated by an off-gas treatment system before release to the atmo iphere.

The off-gas treatment equipment is mounted inside road 1egal, 45-ft trailers to provide the mobility required to support the ISV operations as they progress along the site. For the same reason, the electric power 


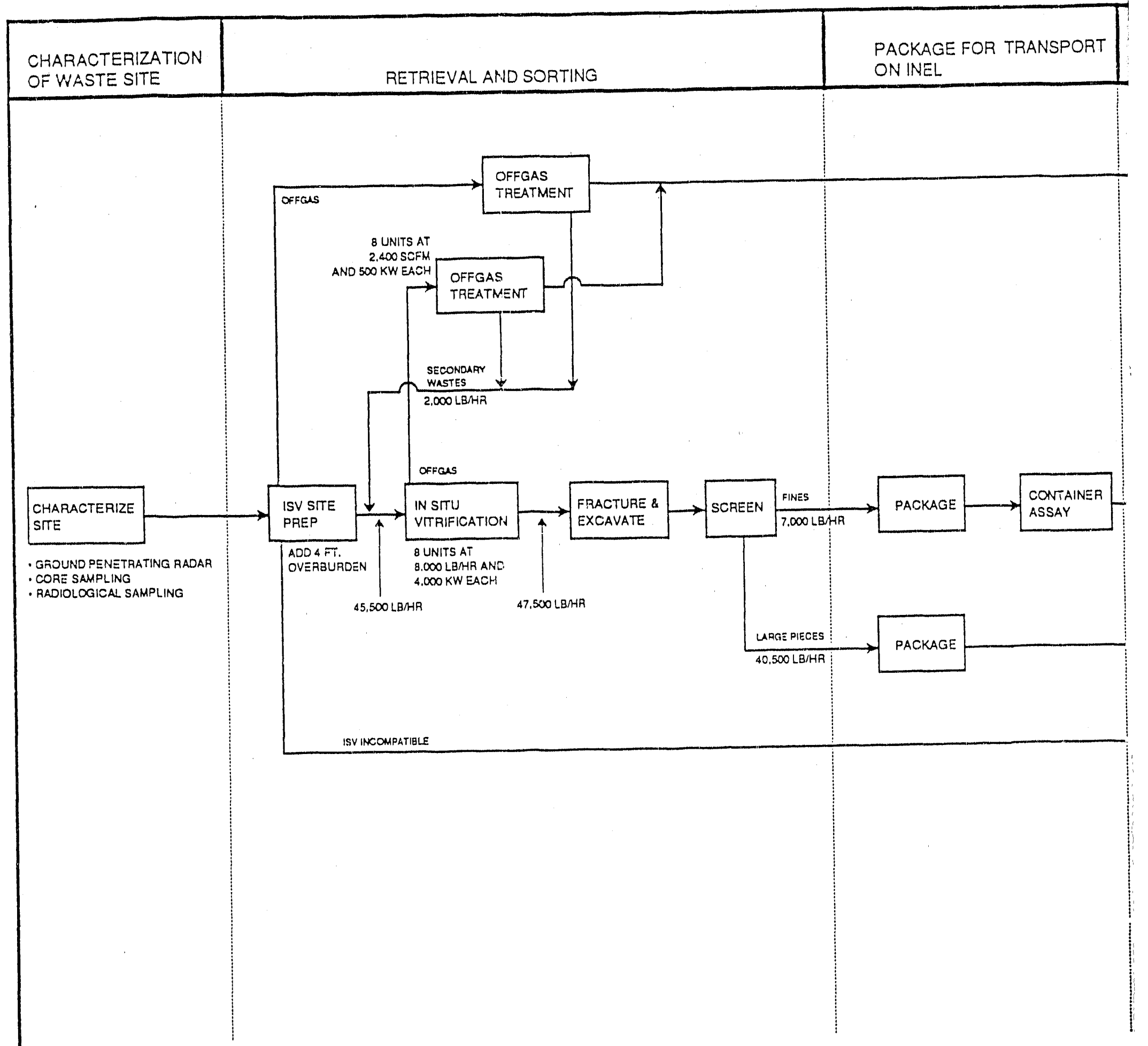

DESCRIPTION:

- SITE IS PREPARED AND IN SITU VITRIFICATION IS USED TO CREATE A LEACH-RESISTANT, HIGH INTEGRITY WASTE FORM.

- WASTE IS FRACTURED AND EXCAVATED; LARGE PIECES ARE PACKAGED, FINES ARE MELTED AND PACKAGED.

- SECONDARY WASTE STREAMS FROM OFFGAS TREATMENT ARE SOLIDIFIED.

- CONTAINERS ARE ASSAYED AND TRU IS SEPARATED FROM LLW FOLLOWING WASTE PROCESSING.

Figure IV-4-1. Process functional diagram for the In Situ Vitrification and Retrieval Processi EGG1103 Systern $(2-E B-3)$. 


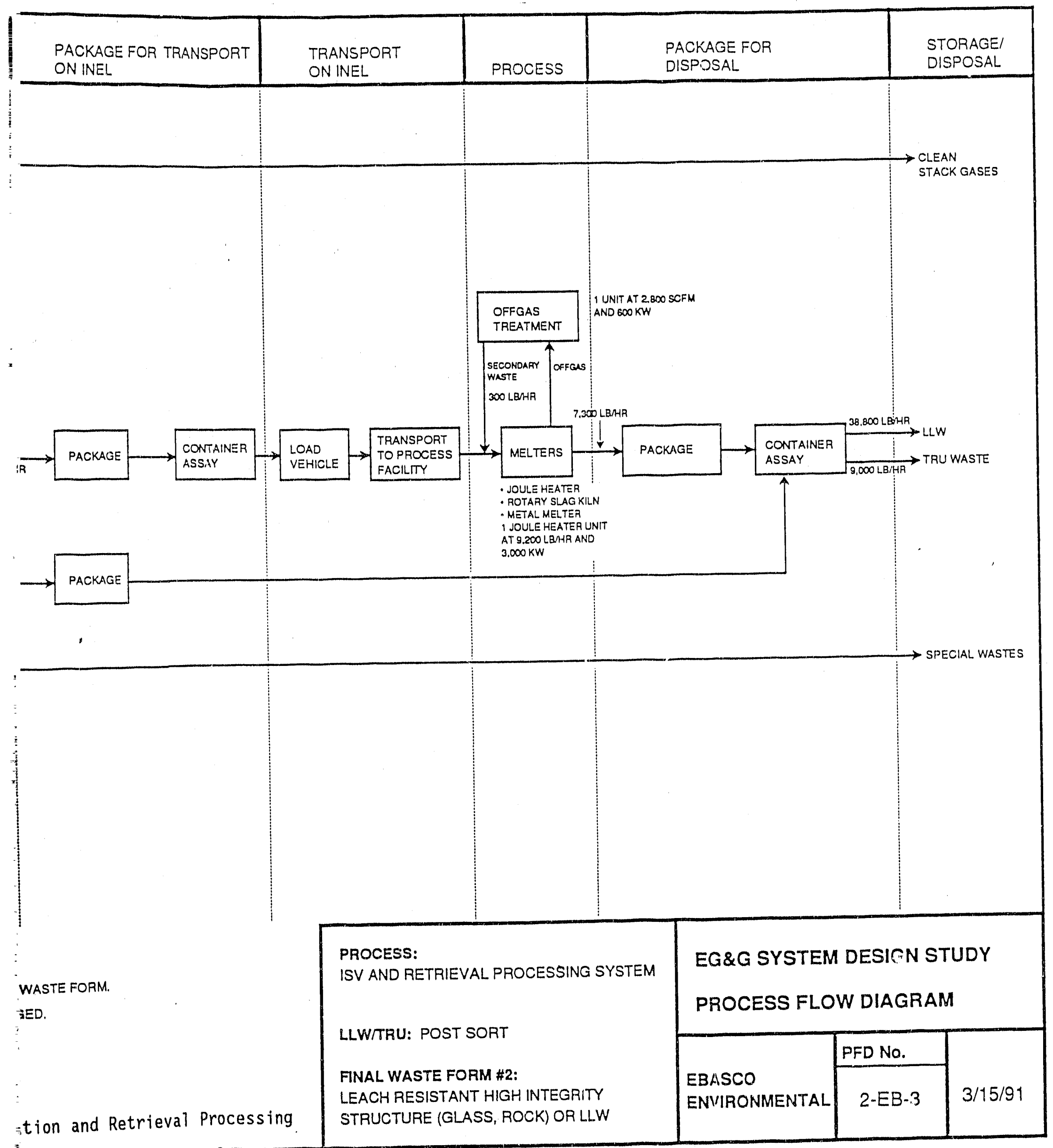




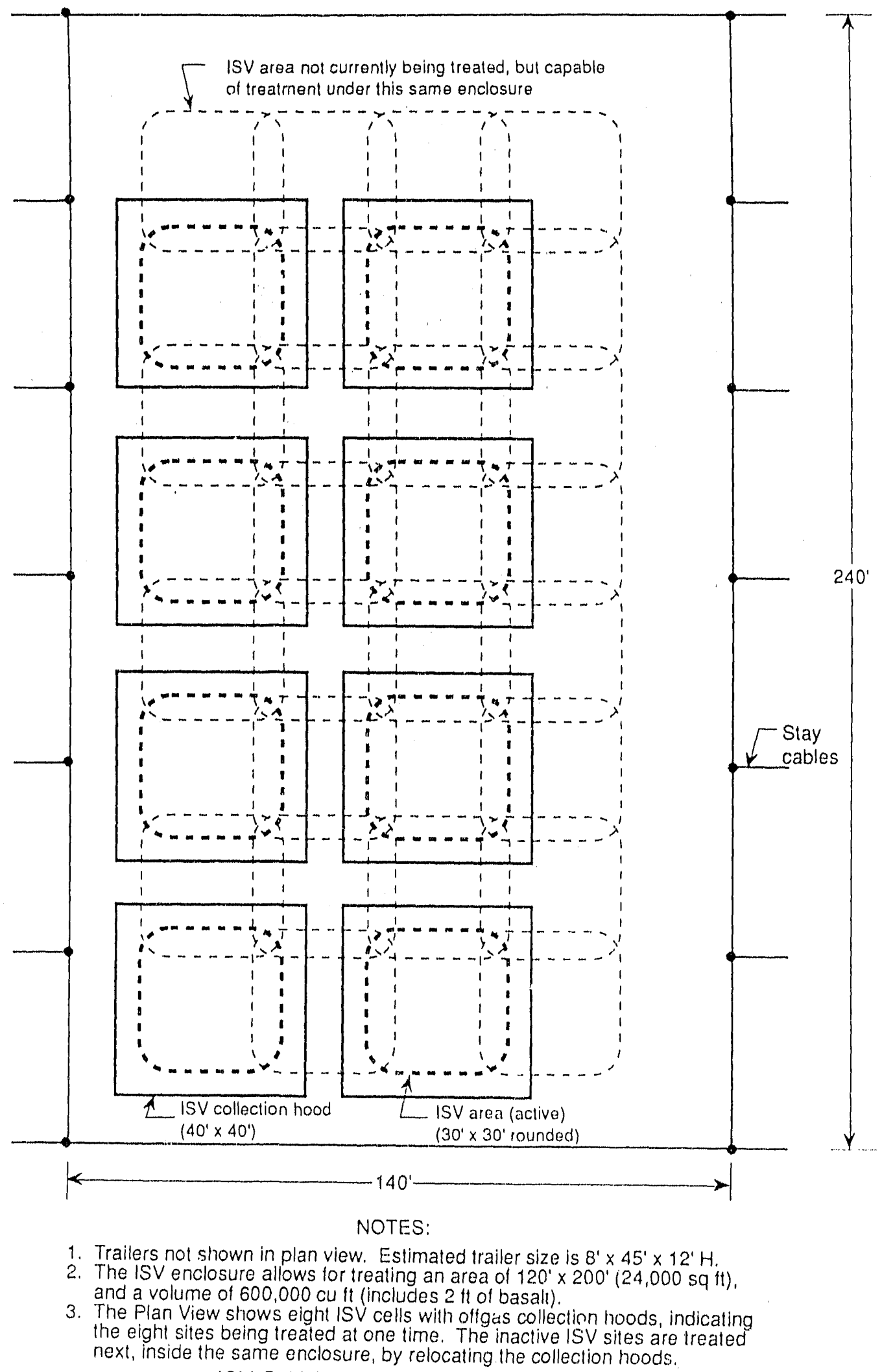

ISV SECONDARY ENCLOSURE PLAN VIEW

(SUSPENDED ROOF REMOVED)

Figure IV-4-2. Secondary containment for the eight operating ISV off-gas collection hoods. 


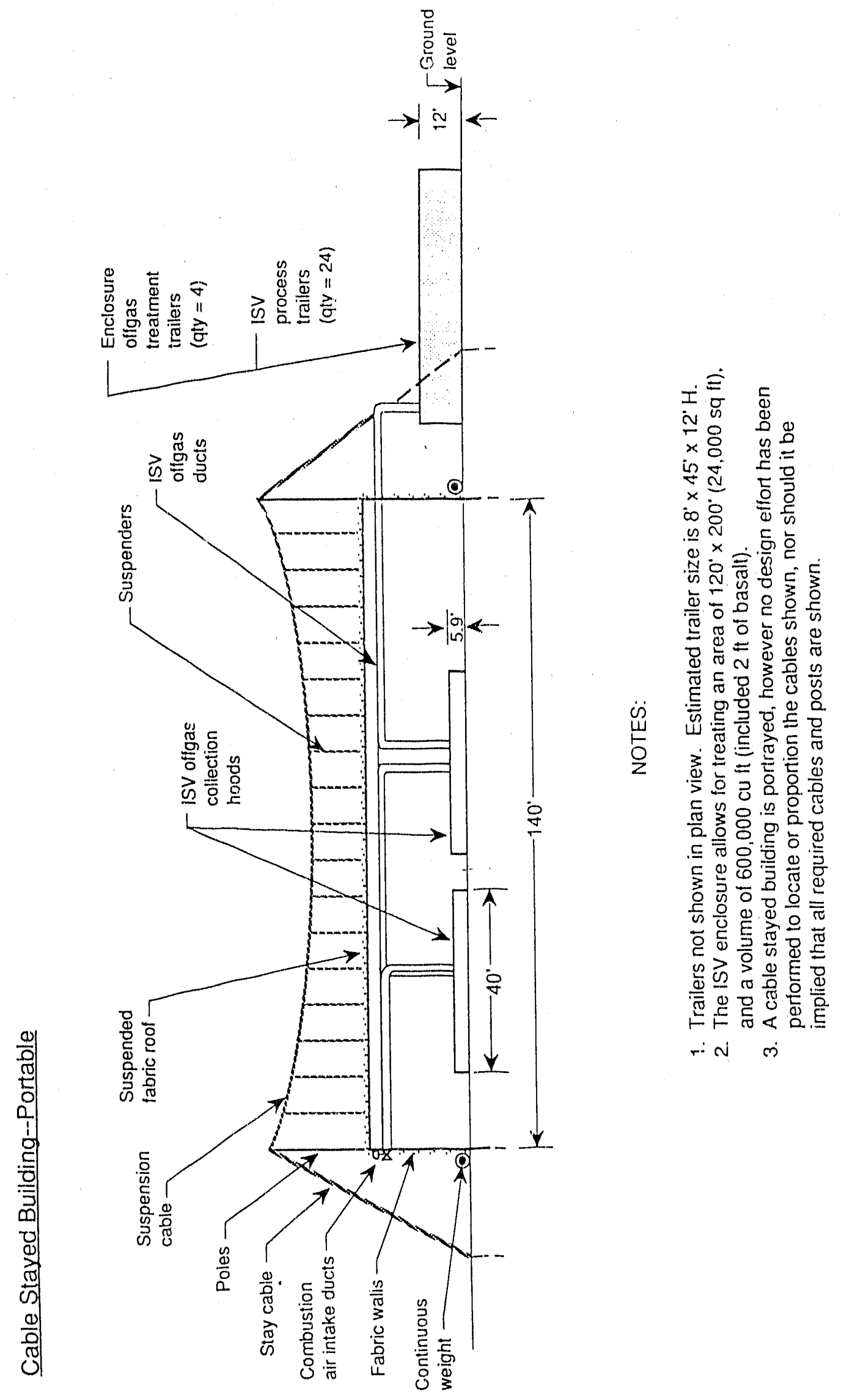

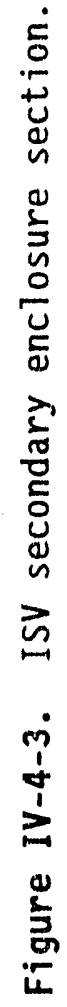


controlling equipment, including the multitap transformer, is located inside mobile trailers.

The thermal treatment facility containing the joule heater, is a moderate risk level facility by definition of the study, as shown in Figure IV-4-4. The facility is expected to be $100 \times 100 \mathrm{ft}$, one story, high bay building. The joule heaters will be located inside individual containment structures within the facility. The facility must be capable of receiving the ISV fines-filled containers and feeding them to the heaters. The off-gas treatment equipment is also located inside containment structure(s) within the facility.

\subsubsection{System Design Requirements}

4.1.5.1 Functional Requirements. The ISV and Retrieval Processing System will immobilize the TRU and LLW at Pits 1-6, 9, and 10 and Trenches 110 at RWMC in a high-integrity, nonleachable glass and package the waste for disposal.

Sufficient site characterization will be conducted to identify waste site areas that are unsuitable for ISV without preparation and to define the preparation required.

Hazardous waste and contaminated soil will be vitrified in place into a molten mass and naturally cooled, forming a high-integrity, nonleachable glass material similar to the naturally occurring obsidian. The individual ISV sites will be sized, and the electrodes positioned and installed so as to maximize homogeneity in the vitrified waste.

The entire remediation process, from site characterization to ISV and melting the fines, to all of the waste packaged and assayed for disposal, will be completed within one year.

All off-gases released during the vitrification processes will be captured, and all contaminants will be removed before release of the gases 


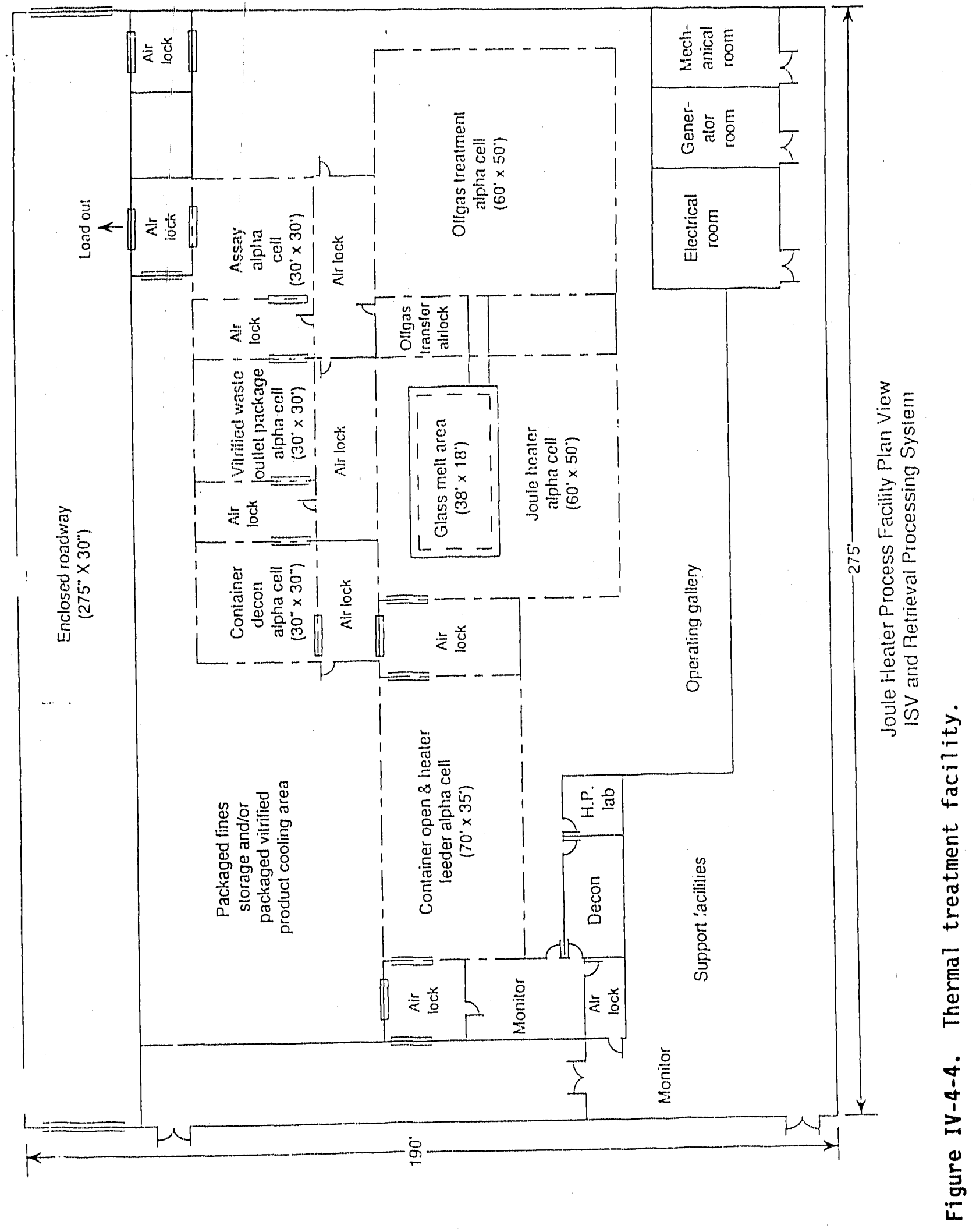


to the atmosphere as required by applicable regulations. The ISV off-gas contamination hood will support combustion and be designed to receive short, high volume bursts of off-gas without escape to the atmosphere before treatment. The joule heater off-gas hood will be designed to withstand the high temperature duty it will be subjected to and maintain the joule heater and its containment structure at a negative pressure compared to the building atmosphere.

The liquid secondary wastes generated by the off-gas treatment systems will be vitrified with the primary waste as they are generated.

The joule haaters will process all of the ISV fines generated by the excavation and fracture operation of the ISV glass into disposable sizes of high-integrity, nonleachable glass.

4.1.5.2 Performance Requirements. Site characterization will be performed using the most efficient methods to safely identify potential ISV incompatible areas within the trenches and pits. Potentially incompatible areas include high densities of metal, large amounts of voids, high concentrations of combustible wastes, and bottled gases. Sufficient information will be gathered for adequate ISV design.

ISV will proceed in such a manner that proper sequencing, sufficient overlap, and proper depth is achieved in the melt to ensure that all of the mixed waste (including contaminated soils) in the RWMC Trenches 1 through 10, and Pits 1 through 6,9 and 10 is remediated and no migration of contaminants outside of the melt or off-gas treatment system occurs. The electrodes at each individual ISV site will be located to ensure that the waste, as characterized, will be completely vitrified into a homogeneous, nonleachable, high integrity waste form.

ISV sites are to be identified, and a vitrification design completed for each. The design will include the amount of clean overburden, frit, and graphite required, the method for vitrification depth detection, and the electrode locations, along with the estimated electrode feed rate required and corresponding voltage control. 
Sites within the trenches and pits that require ISV preparation will undergo the required preparution without releasing contaminants into the atmosphere or outside of the waste site boundary, except for the removal of special wastes.

ISV will be employed on eight waste sites at a time with no less that $70 \%$ process avallability. An ISV plan is to be submitted and approved for the sequence of processing the ISV sites.

The ISV off-gas collection hood will have provisions to provide sufficient oxygen to support complete combustion of the volatile gases that surface during vitrification, will be constructed to withstand the highest anticipated temperatures of combustion expected, and will be designed to contain the largest anticipated volumetric flow rate of off-gases, while maintaining a negative pressure. The off-gas treatment system will capture radioactive and other contaminants and pollutants as required by regulatory agencies for atmospheric release, while producing a minimum volume of secondary wastes.

The ISV secondary enclosure will capture all off-gases that may overwhelm the off-gas collection hood in an unexpected scenario. The enclosure will provide secondary containment for all eight of the operating ISV site. The building will be portable and modular to follow the ISV sites around RLMC and will meet all of the applicable requirements of the INEL facility design criteria. The enclosure will also function as an enclosure around any excavation required during the ISV preparation operation in removing special wastes. The enclosure ventilation air flow will be treated by an off-gas treatment system to remove all contaminants to the required level for release to the atmosphere.

The joule heater will be capable of processing 150 tons of ISV fines per 24-h day, as well as occasional solid secondary wastes from the off-gas treatment systems. Vitrification fluxes will be added, temperatures obtained, and residence time sufficient to produce a high-integrity, non-leachable waste form. The joule heaters will have an availability of no less than $70 \%$. 
Joule heater off-gas hood and treatment systems will maintain a negative pressure on the furnace and containment vessel. Contaminants and pollutants in the off-gas will be captured and removed as required by regulatory agencies. Secondary waste volume will be minimized.

\subsubsection{Interface Requirements}

Accessways and staging areas are required for materials passing into the system boundary. For the RWMC site these include equipment for health safety, site characterization, construction of an enclosure, placement of overburden, special waste extraction, ISV and off-gas treatment, stabilization of secondary waste, and decontamination. The thermal treatment site requires the construction of a facility with delivery capabilities for the joule heaters and support equipmerit. Materials that are added to the system for the ISV system include clean overburden soil, glass frit, graphite, and cap material (soils and plants), while the joule heater requi'es flux material.

Electrical power is required for the system to support the ISV process, the joule heaters, and associated equipment. Each ISV operation will require a multitap transformer varying from 400-4160 V, and a 3.75 MW power supply (this is approximate, the required power could be as high as $5 \mathrm{MW}$, as this is the recommended size for portable generators). In order to operate eight ISV sites at once, $30 \mathrm{MW}$ (perhaps as much as $45 \mathrm{MW}$ ) of consumable power is required.

4.1.6.1 Site Characterization. Site characterization includes further research of the documentation of the waste received at RWMC. In addition, all new characterization of waste inside the pits or trenches is to be accomplished by nonintrusive geotechnical methods to minimize risk of exposure to hazardous and radioactive material, as well as from explosion or fire. It is assumed that these methods can adequately identify the major concentrations of metals and voids in the pits and trenches to allow for ISV preparation of potentially incompatible areas. 
The soil and water content of the soil at RWMC is assumed to be easily vitrifiable. Three waste types currently present difficulties for the ISV process; however, each appears to be surmountable. High metal content can short circuit the current between the electrodes and stop the progress of the molten mass to the required depth. Large amounts of combustibles or contained gases can overwhelm the off-gas collection hood with hazardous gases and escape. Voids not only present the potential for releasing large amounts of contained gas, but also can stop progress of the vitrification process by breaking the continuity of the conductive molten mass as it flows into the empty volume.

Current research on movable electrodes appears to be successful in preventing short circuits. Electrodes can free fall into the waste volume, balancing the weight of the electrodes with the buoyancy of the molten mass, or be lowered at a controlled rate. Resistance between the electrodes is monitored as the electrodes are lowered; a low resistivity indicates the presence of metal and the electrode depth is positioned to be above the metal. The molten glass drops below the electrodes and melts the metal. Slowly the metal is incorporated into the molten glass. The electrodes ride above the molten metal pool until all of the metal is incorporated. It is assumed this technology will prove to be successful in vitrifying large densities of metal found at RWMC.

ISV of high concentrations of combustibles, high Btu liquids, and volatile gases will be accomplished by designing off-gas collection hoods and treatment systems to be capable of capturing and treating a larger volumetric. flow. The hood may be required to withstand higher temperatures for the additional combustibles anticipated, and the required ratio of combustion air supply to the hood may change. Site characterization and engineering safety factors will be used to determine the design conditions of the hood and treatment systems. Bacause the characterization of RWMC is not expected to be very accurate for nonmetals and the serious safety hazards presented by an unanticipated scenario, a structure providing a secondary enclosure around the operating ISV off-gas hoods is required. 
Losing ISV electrical continuity in the molten glass when voids in the buried waste (including empty containers) are quickly filled with the magma can be avoided by ensuring there is enough magma to fill the void without breaking the blanket of molten glass. This is accomplished with severa? feet of overbuiden.

As a result of these methods, most, if not all, of the wastes at RWMC are expected to be ISV compatible without disturbing the burial grounds.

4.1.6.2 In Situ Vitrification Preparation. Clean overburden soil will be required to provide a sufficient molten glass mass to fill in voids without loss of continuity, to increase the capture of contaminants, and to provide sufficient thermal mass to melt and vitrify high concentrations of metal successfully.

Only one pit is expected to require the excavation of a special waste (as identified during the site characterization) that cannot be vitrified. The excavation enclosure facility will be the same structure used to provide double containment over the ISV process, using the same off-gas treatment system as for the ISV.

4.1.6.3 In Situ Vitrification. ISV of all RWMC mixed wastes must be complete in five years to allow the molten glass enough time to cool sufficiently to excavate and fracture the material. A vitrified waste site this size is estimated to take one year to cool, with heat transferring to the surface and to the soil surrounding the melt. A molten mass surrounded on two or four sides by other molten masses has a much reduced heat transfer surface; therefore, it will take longer to cool. A heat transfer analysis is required to confirm the assumed cooling time required.

4.1.6.4 Excavate and Fracture. The excavation and fracture of the hardened ISV waste will involve the use of as much excavation and mining equipment as required to reduce the size of the glass into packable sizes. A variety of sizes is required to obtain the high density packing desired for volume minimization of disposed waste. The experience of Battelle in reducing ISV glass to 1 -ft sizes resulted in very little generation of fines. It is 
assumed, however, that some crushing or pulverization will be required to obtain the smaller pieces to fill the voids between the larger pieces during packaging.

4.1.6.5 Joule Heatur. A large joule heater unit will be used to melt the fines resulting from the fracture and excavation of the vitrified waste. Because of the lower operating temperatures required (for the sake of extending the life of the refractory), aditives are usually required with this type of material to achieve a uniform melted product.

4.1.6.6 Assay of Vitrified Waste. A final assay is performed to separate TRU waste from LLW. The proportion of remediated TRU and LLW packaged for disposal is assumed to be the same as the ratio of untreated waste.

4.1.6.7 Off-gas Treatment systims. The off-gas treatment systems serving each of the ISV operations and joule heaters are assumed to be very similar in design and function. The treatment system cools, scrubs, sorbs organics, and filters the gases collected before releasing to the atmosphere. System components typically include a gas cooler, wet scrubber, off-gas-toglycol heat exchanger, process solution scrub tank, scrub solution pump, condenser, mist eliminators (vane separators), heater and charcoal filter, blower, and HEPA filter bank.

Secondary waste streams from the off-gas treatment systems include spent scrubbing solution from a slurry recycling system, spent resin from the slurry recycling system, spent HEPA filters, and activated carbon filter regenerant. All solid secondary wastes are vitrified as they are generated, either in the ISV operations or the joule heater. Far fewer contaminants are expected to be generated from the enclosure off-gas treatment system and are, therefore, ignored at this level of system definition. 


\subsection{System Assessment}

\subsubsection{Current Status of Unit Operations}

4.2.1.1 Site Characterization. Geophysical techniques offer a relatively simple, nonintrusive method of characterizing the RWMC site. Ground penetrating radar (GPR) is useful in detecting buried metallic objects such as drums, pipes, and cavities and in the delineation of the margins of the burial pits and trenches. Magnetics and electromagnetics (EM) can be used as supporting techniques to identify the locations of buried metallic objects and pit margins as well. The GPR and magnetometer are hand-held instruments that can be used at the surface and are rapid and cost effective. All are proven techniques that have been used extensively for similar site characterizations in the past. Most recently, Ebasco has used GPR and EM to identify pit boundaries and drum locations at the dump sites on McChord Air Force Base in Washington and at the Waste Disposal Inc. Superfund Site in California.

\subsubsection{In Situ Vitrification Preparation. Uncontaminated dry soil} must be placed atop trenches and pits suspected to contain large amounts of combustibles or voids. This overburden improves capture of contaminants in the glass, and reduces the chance of losing electrica contiruity when the molten glass encounters a void. The only special aspects of the technology involved in depositing the overburden are those radiation safety measures required for entering RWMC and decontamination requirements required before exiting the site.

Techniques involved in the removal of special wastes that are not vitrifiable, such as large masses of dense metal, are similar to the techniques used in the retrieval subsystem to excavate objects. Capturing any released radioactive soil-gas, dirt, and dust during the operation can be accomplished by an enclosure.

4.2.1.3 In Situ Vitrification. ISV has been selected for large-scale use at 10 private, EPA-Superfund and U,S. Department of Defense (DOD) sites 
and is being considered for numerous others. Approximately 120 ISV operations have been performed at all test scales to date, according to a representative of Battelle, including approximately 55 engineering-scale, 20 pilot-scale, and 8 large-scale tests since 1985. Two of the large-scale tests included the treatment of radioactive contaminants. The engineering-scale tests were performed in a container $6 \mathrm{ft}$ in diameter and 8 - $\mathrm{ft}$ deep. Pilot-scale testing was performed in the ground with electrode spacing of about $5 \mathrm{ft}$ for a melt area of about $10 \mathrm{ft}^{2}$. Large-scale tests were in situ with electrode spacing of about $18 \mathrm{ft}$ for a melt area of $30 \mathrm{ft}^{2}$.

ISV is a technology that is relatively mature in the remediation of contaminated soils, although no commercial ISV operations have taken place to date. Two contracts have been signed wit! the Geosafe Corporation to treat polychlorinated biphenyl (PCB) and pesticide-contaminated soils, and commercial equipment is available to perform the remediation. Currentiy, ISV is being evaluated for meeting the waste form concentration requirements for a Toxic Substances Control Act permit to treat PCBs.

Two large-scale ISV tests have been performed on radioactive soils. The tests indicate the majority of the heavy metal contaminants and radioisotopes dissolve into the molten glass matrix. Typical reported capture efficiency of semivolatile and refractory metals in the glass is $99.9 \%$, while the capture efficiency in the glass matrix for lead is typically $90 \%$. The metal contaminants not captured in the glass are reportedly carried out with the off-gases and treated. The capture efficiency of particulates in the off-gas system is reported at $99.9 \%$ (Geosafe Corporation, 1989).

ISV is less mature in the remediation of organics (debris, municipal type waste in soils, etc.), underground tanks and drums, and solid waste burial grounds. TRU waste at RWMC is located in solid waste burial grounds that contain a variety of waste forms including organic contaminants, organic wastes, empty containers, and metal. ISV technology development and demonstrations specific to these types of waste forms are required to ensure that ISV process is applicable to the RWMC TRU wa te remediation project and that any limitations are identified and corrected in order to ensure smooth operation. 
Overwhelming the off-gas treatment system is the primary limitation in vitrifying organics. This was addressed by designing a larger, heavy duty off-gas collection and treatment system. In addition, a secondary enclosure is included to ensure that any off-gas that does escape from the hoods is captured and treated. The enclosure must be large enough to collect any burps from the hood, although the logistics of building and locating such an enclosure that can be placed over all of the operating ISV units will be challenging. The idea of building the enclosure to cover eight ISV sites and of moving the enclosure along with the operation may be unrealistic, especially if the enclosure is considered a low-hazard facility. Several large enclosures to cover all of the trenches and pits may be required instead.

Metal content and voids associated with the underground tanks and solid waste burial grounds either short circuit the electrodes burning them off, or break the conductive path when the melt rapidly fills a void. Sufficient overburden to fill the voids without breaking the conductive path can overcome the problem with voids, except for the larger voids. Moving electrodes is an ISV technique described in the 1-EB-2 F\&OR. The technique has been successful in vitrifying material containing $25 \%$ metal by weight in an engineering-scale test by Battelle in April 1990. A test is scheduled for April 1991 by Battelle to evaluate underground tank vitrification using the moving electrode technique.

There is concern over whether organic volatile gases generated during ISV are driven away from the molten mass into surrounding soil or drawn into the hot melt where they dissolve or rise to the surface to be treated by the off-gas system. ' This issue requires resolution assuring the vapors from the pyrolysis of the organic contaminants are captured by either the glass matrix or the off-gas treatment system.

The greatest depth achieved by ISV to date is $19 \mathrm{ft}$ at a non-radioactive waste test site during ISV of a trench containing plutonium-contaminated liquid in Hanford's 200 Area. The ISV process was shut down when the molten

a. Private communication from H. L. Penberthy, to Thomas Dunne, EPA, September 7, 1990. 
surface area approached the perimeter of the off-gas collection hood. ISV depth is determined by the progression of the melt, which can be limited by electrode short circuits, breaks in the conductive glass blanket, or the lack of sufficient molten mass temperatures. As the molten mass grows, the surface area in contact with the surrounding soil increases which, reduces the flux of thermal energy. At some point the power produced at the electrodes is insufficient to maintain the melt. This limitation may be overcome by advances in electrode technology, and the moving electrode technique may make deeper melts possible as the molten pool of metal that collects at the base of the melt below the electrodes effectively focuses the electrical power at the base, wiich should improve downwa: a propagation of the melt.

4.2.1.4 Off-gas Treatment. Off-gas treatment is required for the primary hood over the ISV process, joule heater furnace, as well as ventilation air required to maintain negative pressure inside the ISV and joule heater secondary enclosures. HEPA filters (and perhaps activated carbon filters) will be used for removing radioactive particles from the ventilation air, as is currently being used on the majority of glove boxes enclosing radioactive processes. The off-gas treatment systems supporting the ISV and joule heater processes must treat much hotter gases and higher contaminant and products of combustion concentrations than the secondary enclosure off-gas treatment systems. The technology used for the treatment of off-gas generated from these thermal processes (products of combustion, acid gases, and radioactive particulates) utilizes a combination of well known thermal process exhaust gas treatment technologies, including quenching, $\mathrm{pH}$ controlled scrubbing, temperature and dew point tempering, particulate filtration (HEPA filters), and activated carbon adsorption.

4.2.1.5 Fracture and Excavate. Fracturing the vitrified waste may be accomplished either by cryogenic fracture, chemical expansion fracture, or by mechanically breaking the material. Mechanical fracturing with conventional heavy equipment, such as a ram-hoe or rock saw, could cause dust problems, but containment of the blast dust and exhaust gases may be achieved by enclosures, $\because: 1$ ters, and chemical dust suppressants.

4.2.1.6 Screen. Screening technologies to sort radioactive materials by size include disc screens, sliding screens, bar screens, and trommels. In 
order to minimize dust production and treatment requirements (considering also remote operations requirements), a progression of sliding screens starting with a bar screen(s) in a continuous process is probably the best technology to use. Screening technologies are well-developed.

4.2.1.7 Melters. The joule heater technology to treat hazardous wastes was developed from the industrial glass melter technology. The hazardous waste treatment technology using the joule heater was developed in France in the 1970s and is commercially avatlable. The construction of a furnace to process 135 ton/d of the ISV fines is technically feasible, as glass furnaces have been built and are reportedly operating to process up to $200 \mathrm{ton} / \mathrm{d}$ of giass.

A $200 \mathrm{lb} / \mathrm{h}$ pyroconverter furnace operates at the Monsanto/Mound Facility in Miamisburg, Ohio and radium-contaminated zircon sludges were melted and casted for Teledyne/Wah Chang in Albany, Oregon. Demonstrations of rad waste glassification, including remote operation, have been presented to the Atomic Energy of Canada, the Department of Energy at West Valley, New York; EG\&G at Idaho Falls, Idaho; and Defense Waste Processing Facility at the Savannah River Site, South Carolina.

Battelle provided the joule heater used at the Savannah River Site which began operation in 1988. This is a remote operated furnace, $11 \times 23 \times 17 \mathrm{ft}$, processing high level sludge and liquid waste.

\subsubsection{Program Implementation Risks}

This section identifies major concerns associated with program implementation assuming that In Situ Vitrification and Retrieval Processing system is selected. Furthermore, risk of accomplishing the Program objectives is qualitatively characterized. Summary of results and major areas of concern are shown in Table IV-4-1. Program mission and objectives are given in volume II. 


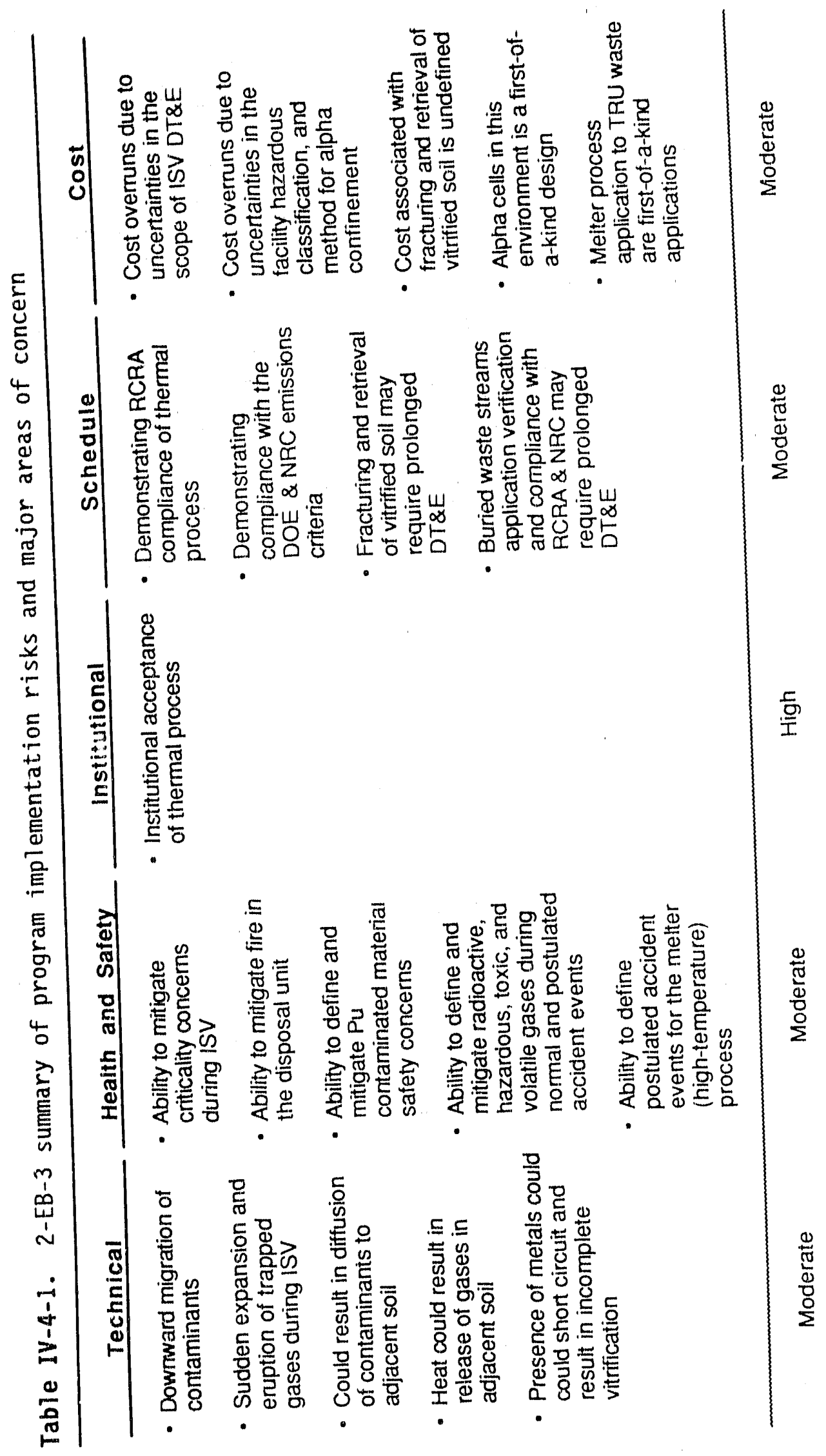




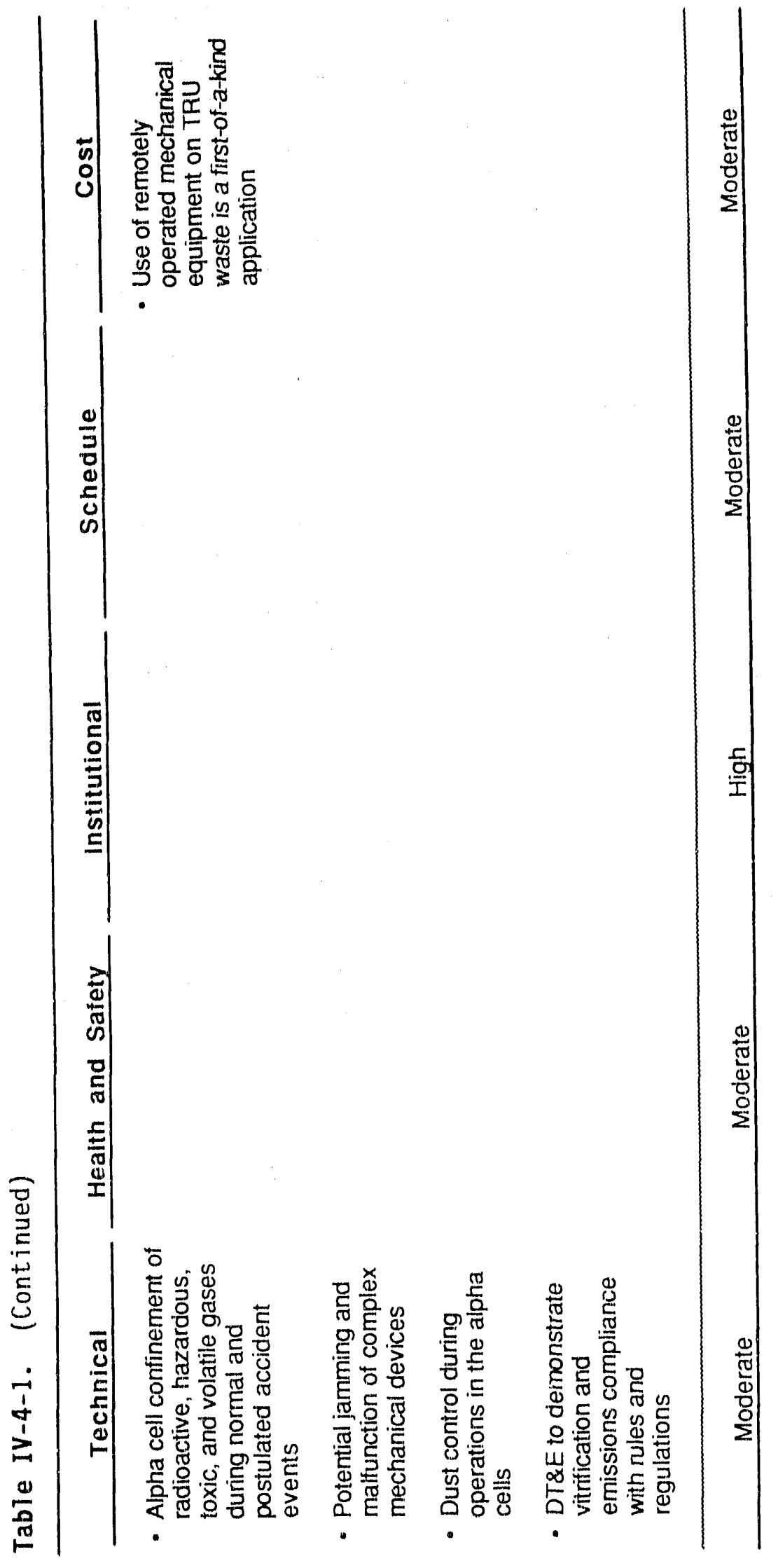


4.2.2.1 Performance Objectives. Baseline cleanup standards for SDA pits and trenches at RWMC cannot be established until an ROD pursuant to the CERCLA process is reached. These standards will be derived ARARs under CERCLA, standards set by risk assessments, and State and local statutes. Since no specific requirements have been formally established at this time, it is assumed that the major ARARs for this system will be RCRA rules, the appropriate NRC regulations and guides, and DOE regulations and orders.

In the In Situ Vitrification and Retrieval Processing System, the major uncertainties listed below have been identified as areas of concern in the achievement of the performance objectives.

- Potential for incomplete vitrification. Incomplete processing could occur in situations where large volumes of metal are present and create a short circuit between the electrodes. In this situation, the offending objects may require excavation and remova1. It is assumed that areas of incomplete vitrification will be identified in the excavation phase of the process and reprocessed at the melter.

- Processing of the retrieved waste will be conducted in several alpha cells. These cells will contain dust and any radioactive, hazardous, toxic, and volatile gases that may become airborne during the waste handling and processing operations. In the case of ISV, the dusting and potential for airborne gases are less than other options. However, the facility is still considered firstof-a-kind, with many uncertainties regarding the Program's ability to develop a cost-effective design. The design must provide for efficient operation of the complex mechanical equipment such as size reduction machines, manipulators, waste conveyors, and related components installed inside alpha cells.

- The melter unit operation is well understood and several technology options are available. DT\&E will be needed to demonstrate (a) application to TRU/ISV waste streams, and 
(b) compliance with RCRA, EPA emisston standards, and NRC and DOE requirements.

- There are some uncertainties about the additives needed to produce a high-integrity leach resistant vitrifted waste form. More extensive DT\&E in this area will be needed.

Based on the above discussions, it is believed that the overall risk associated with achieving the performance objectives is moderate.

4.2.2.2 Health and Safety objectives. The key health and safety objectives for the Burfed Waste Program are to (a) identify the hazards of the remedial action operation, and (b) provide measures to eliminate, control, or initigate identified hazards. In this system, major areas of uncertainty are

- The ability to define postulated accident events (such as fire, criticality, unforeseen release of toxic/hazardous material) for the alpha cells; and provide mitigation measures to satisfy the RCRA, NRC, and DOE requirements. Potential for exposure with this system is low when compared with other alternatives where the waste matertal is excavated and handled in raw form. Since the raw waste is largely processed in-place, the risk of exposure to contaminants is minimized. The greatest risk for exposure to ionizing radiation and hazardous chemicals occurs with accident scenarios where there is a break in a line to the off-gas treatment system, or uncontrolled venting to the atmosphere. However, given that the vitrification process is effective in destroying organics and capturing most inorganics in the melt, accidents are more easily defined and mitigated.

- Potential diffusion of hazardous chemicals into the surrounding soils. As the melt progresses, some contaminants are volatilized and could migrate into the surrounding soils. Preliminary testing shows the vitrification rate is greater than the diffusion rate of volatilized contaminants, and the insulating nature of the soil

IV -103 
protects against elevated temperatures. Consequrntiy, the boundary zone is minimized where the contaminants are volatilized are destroyed in the extreme temperatures of the melt.

In general, the safety risks inherent. with this system include the potential for industrial accidents, spread of contamination, and exposure to ionizing radiation and hazardous chemicals. The greatest risk to worker safety with this system during ISV operations is industrial accidents (e.g., electrocution, burns, heavy equipment accidents, etc.). However, with worker training and proper equipment, these risks can be minimized. At this stage of the system concept, it is believed that the overall safety risk is moderate.

4.2.2.3 Institutional objectives. A key institutional objective is to involve the public, as required by CERCLA and NEPA, in the process of selecting a remedial action for the Buried Waste Program. Public support for the retrieval aspect of this system is anticipated to be high because it is part of a remedial action strategy consistent with the public and the State of Idaho's desire to retrieve the SDA waste. Public support of the melting aspect is considered to be low because it gives the impression of a thermal process. The overall risk associated with achieving the institutional objectives is believed to be high.

4.2.2.4 Schedule objectives. The objective of the Buried Waste schedule is to reach approval for Title II start by mid 1999. This is based on the assumptions that an ROD will be reached by end of FY 2001. The schedule objectives for completion of the Buried Waste Program remedial action is by FY 2019. The following major uncertainties in achieving these objectives have been identified.

- The extent of DT\&E required before final system design and construction may prolong the schedule. 
- The alpha enclosure is a relatively complex first-of-a-kind structure and could be subject to prolonged DT\&E, design, and construction. However, with advanced planning, uncertainties in achieving schedule objectives could be reduced.

- Use of remotely operated mechanical equipment for sorting, conveying, size reduction, etc., and handling of TRU waste is a first-of-a-kind application. Schedule uncertainties from prolonged DT\&E, design, and construction are anticipated. Again, with advanced planning uncertainties in achieving schedule objectives could be reduced.

- Demonstration of melter is needed for ISV streams application; and compliance with RCRA, NRC, and DOE requirements may require prolonged UT\&E.

Based on the above discussions, and an assumption that the Program implementation activities will begin in FY 1992, the schedule risk is believed to be moderate.

4.2.2.5 Cost objective. Assessment of the cost objective is a qualitative characterization based on the uncertainties involved in defining a reasonably accurate cost estimate for the system. Accordingly, both in situ vitrification and joule heating have been the subject of considerable research and development, including some large-scale testing. Consequently, the costs associated with the process itself are well-defined. Some of the major uncertainties are presented below:

- The extent of additional DT\&E required before final system design and construction may cause cost overruns.

- The use of alpha cell in the given waste processing environment is a first-of-a-kind design and could be subject to cost overruns because of prolonged design development. 
- Use of remotely operated mechanical equipment for container opening, sorting, size reduction, and handling of TRU waste is a first-of-a-kind application. Cost uncertainties are anticipated until design, based on DT\&E, is well into maturity.

- Use of incinerator and melter for buried waste is a first-of-akind application. Cost uncertainties are anticipated until design, based on DT\&E, is well into maturity.

Based on the above discussions, the cost risk is believed to be moderate.

\subsubsection{Unit Operations Pro and Con Analys is}

ISV is an attractive treatment technology. In a single process, organic contaminants are destroyed and inorganic contaminants are immobilized in a leach-resistant, high integrity structure. Also, this process does not require the raw waste material to be exhumed before treatment, saving both the cost and the exposure associated with retrieval, packaging, and pretreatment of the raw waste. However, areas containing special waste (large metal objects, etc.) may not be suitable for ISV and may require exhumation and treatment by special processes. Waste volume reduction of 40 to $50 \%$ can be expected wich the process. ISV is energy efficient when compared to other thermal treatment technologies because of electrical energy conversion efficiency and relatively little heat lost to the atmosphere with the offgases. For example, ISV typically consumes only one-half to one-third of the amount of energy required for incineration.

However, ISV is an innovative technology and, as such, requires additional DT\&E. There are still some questions that will need to be resolved. For example: Will volatile organic contaminants migrate into surrounding soils or be consumed in the melt? How significant is the danger of setting afire the buried waste adjacent to the vitrification operation? Will compressed gas cylinders or large pockets of volatile organics overwhelm the off-gas treatment system? How will large metal objects in the waste

$$
\text { IV }-106
$$


affect the operation? Can criticality concerns be resolved satisfactorily? How well can the extent of the melt be defined during operation? Will the electric power consumption requirements have a negative impact on the local power grid? These issues will need to be resolved before ISV can be implemented as a full-scale remedial technology at RWMC.

In terms of off-gas treatment requirements, ISV can generate as low as one-tenth of the off-gas volume that equivalent incineration operations generate, and ISV does not produce $\mathrm{NO}_{x}$ because of the high temperature and reducing environment of the process. Off-gas volumes become especially significant with radioactive waste processing because of the amount of HEPA filters required to remove small particles.

riacturing and retrieving the vitrified mass will require additional DT\&E. One established method is to drill into the embedded graphite electrodes and use shaped charges to fracture the monolith into large blocks. However, this could create significant airborne plutonium-contamination problems. The use of saws or heavy equipment to break the monolith will also be difficult, because the vitrified mass has tensile and compressive strengths greater than that of unreinforced concrete.

For melting the fines associated with fracturing and retrieving the vitrified mass, several technologies were considered, such as a joule heater, an in-can melter, and a slagging rotary kiln. These the:rmal technologies were considered applicable for treating the ISV fines because they are capable of handling solids and they produce a leach-resistant, high-integrity structure. of the three technologies, the most well-established and commercially available is the slagging rotary kiln, and the least developed is the in-can melter. Joule heaters are commonly used in the glass making industry, and large commercial units are available. For each of these technologies, remote operation is possible and special additives will be required to achieve the desired molten glass viscosity.

The joule heater was selected as the most promising technology. Although the in-can melter is similar to the joule heater and has the 
advantage of processing the waste in its final container, it requires more electric power and is less developed as a treatment technology. The joule heater has several advantages over the slagging rotary kiln. It uses electricity instead of a combustible fuel, yielding greater energy efficiency and lower off-gas treatment requirements. Also, the final product is more consistent from a joule heater because of the flowing pool of glass. In a rotary kiln, the fines are tumbled in a rotating chamber and may not have an adequate residence time in the slag pool to be completely incorporated into the molten mass. Although both operating chambers are subject to corrosion at the elevated temperatures, the rotating combustion chamber of the rotary kiln tends to wear more quickly. Overall, the slagging rotary kiln is the most expensive alternative ( 3 to 16 times more expensive than a joule heater).

\subsubsection{Unit Operations Lead-Time Estimates}

Table IV-4-2 illustrates the unit operations DT\&E duration anticipated. ISV has been the subject of considerable research and development in the last five years, and much progress has been made. Consequently, it is estimated that only one or two years of bench-to pilot-scale work will be necessary for this technology. Because of the research and development work already performed, field demonstrations can begin immediately, before the research and development phase is entirely complete. The primary focus of development efforts will need to be on full-scale field demonstrations under conditions likely to be encountered at RWMC. The field demonstrations could take up to five years to complete.

Fracturing and excavating the vitrified mass will require two or three years of development. Although the research can begin any time, full-scale demonstrations cannot begin until large vitrified masses become available from the ISV field demonstrations. 


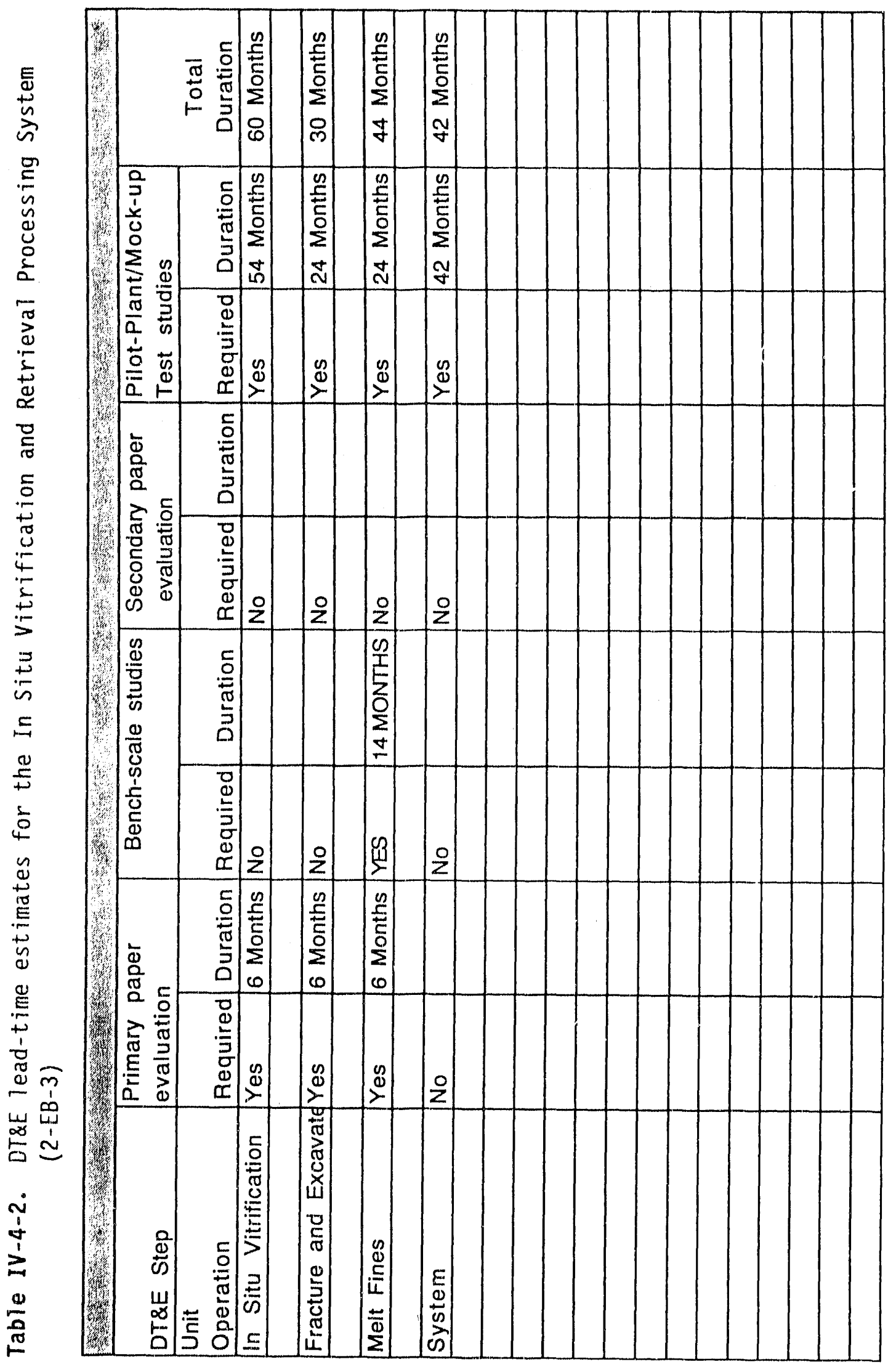


Joule heaters, to be used in melting the fines remaining from fracturing and excavating the vitrified mass, have been used in the glass making industry for some time. Given the technology's state of development, approximately two years of bench scale and initial studies will be necessary to fully adapt the process to handle the plutonium-contaminated fines. Pilot-scale demonstrations can begin any time after that, given that vitrified material remaining from ISV testing will be readily available. These demonstrations will require approximately two years to complete.

Construction of equipment and facilities will be relatively simple for the on-site ISV operation, because no permanent structures are required. However, a permanent moderate hazard facility will be required for the melting operation. Although the facility required is relatively small, it will take at least a year to construct.

The operation phase will require six years to complete. This assumes that the ISV operation will require five years to complete and that the melting process begins one year after the start of the ISV operation. At least a year will be required to allow the vitrified mass to cool sufficiently before it can be fractured and excavated.

\subsubsection{Rough Order Magnitude Cost Estimates}

An ROM cost estimate for the system is provided in the Table IV-4-3. The DT\&E costs are based on information derived from DT\&E progress reports. Demonstration costs are based on the cost estimated for a single full-scale process unit. In addition to the assumptions given in Section 1 , the following system-specific assumptions were used in preparing the cost estimate. 
Table IV-4-3. Rough order of magnitude cost estimates (2-EB-3)

\begin{tabular}{|c|c|c|c|}
\hline $\begin{array}{l}\text { Cost } \\
\text { Code }\end{array}$ & Cost Items & $\begin{array}{c}\text { Normalized } \\
\text { Cost } \\
(\$ \times 1000) \\
\end{array}$ & $\begin{array}{c}\text { Modifled } \\
\text { Cost } \\
(\$ \times 1000)\end{array}$ \\
\hline 1.0 & Studies and bench scale costs & & \\
\hline 1.1 & Manpower costs during research & $\$ 0$ & $\$ 4, i 47$ \\
\hline 1.2 & Equipment costs & $\$ 3,000$ & $\$ 3,000$ \\
\hline 1.3 & Installation costs & $\$ 300$ & $\$ 300$ \\
\hline \multirow[t]{2}{*}{1.4} & Contingency & $\$ 825$ & $\$ 1,862$ \\
\hline & Subtotal 1.0 & $\$ 4,125$ & $\$ 9,309$ \\
\hline 2.0 & Demonstration costs & & \\
\hline 2.1 & Manpower cost during construction & $\$ 10,368$ & $\$ 10,368$ \\
\hline 2.2 & Design cost $(30 \%$ of 2.5$)$ & $\$ 4,961$ & $\$ 4,961$ \\
\hline 2.3 & lispection cost $(7 \%$ of 2.5$)$ & $\$ 1,157$ & $\$ 1,157$ \\
\hline 2.4 & Project administration (10\% of 2.5$)$ & $\$ 1,654$ & $\$ 1,654$ \\
\hline 2.5 & Construction cost & & \\
\hline 2.5 .1 & Building structure costs & $\$ 8,101$ & $\$ 8,101$ \\
\hline 2.5 .2 & Equipment costs & $\$ 4,970$ & $\$ 4,970$ \\
\hline \multirow[t]{2}{*}{2.5 .3} & Indirect $(20.9 \%$ of 2.5$)$ & $\$ 3,464$ & $\$ 3,464$ \\
\hline & Subtotal of 2.5 & $\$ 16.535$ & $\$ 16,535$ \\
\hline 2.6 & Construction marlagement costs $(27.8 \%$ of 2.5$)$ & $\$ 4,746$ & $\$ 4,746$ \\
\hline \multirow[t]{2}{*}{2.7} & Contingency & $\$ 9,855$ & $\$ 9,855$ \\
\hline & Subtotal 2.0 & $\$ 49,275$ & $\$ 49,275$ \\
\hline 3.0 & Production construction costs & & \\
\hline 3.1 & Design cost $(30 \%$ of 3.4$)$ & $\$ 25,146$ & $\$ 28,713$ \\
\hline 3.2 & Inspection cost $(7 \%$ of 3.4$)$ & $\$ 5,867$ & $\$ 6,700$ \\
\hline 3.3 & Project administration ( $10 \%$ of 3.4$)$ & $\$ 8,382$ & $\$ 9,571$ \\
\hline 3.4 & Construction cost & & \\
\hline 3.4 .1 & Bullding structure costs & $\$ 41,065$ & $\$ 50,466$ \\
\hline 3.4 .2 & Equipment costs & $\$ 25,195$ & $\$ 25,195$ \\
\hline \multirow[t]{2}{*}{3.4 .3} & Indirect $(20.9 \%$ of 3.4$)$ & $\$ 17,559$ & $\$ 20,050$ \\
\hline & Subtotal of 3.4 & $\$ 83,819$ & $\$ 95,711$ \\
\hline 3.5 & $\begin{array}{l}\text { Construction management costs and construction management } \\
\text { reserve }(26.5 \% \text { of } 3.4)\end{array}$ & $\$ 24,056$ & $\$ 27,469$ \\
\hline \multirow[t]{3}{*}{3.6} & Contingency $(25 \%$ of 3.1 through 3.5$)$ & $\$ 36,818$ & $\$ 42,041$ \\
\hline & Subtotal 3.0 & $\$ 184,088$ & $\$ 210,205$ \\
\hline & Total Capital Cost $(1.0,2.0$, and 3.0$)$ & $\$ 237,488$ & $\$ 268,789$ \\
\hline 4.0 & Annual operating and maintenance costs & & \\
\hline 4.1 & Operating costs & $\$ 11,405$ & $\$ 11,405$ \\
\hline 4.2 & Utility costs & $\$ 4,231$ & $\$ 4,231$ \\
\hline 4.3 & Materlal costs & $\$ 5,315$ & $\$ 5,315$ \\
\hline 4.4 & Maintenance costs & $\$ 7,604$ & $\$ 7,604$ \\
\hline \multirow[t]{2}{*}{4.5} & Contingency & $\$ 7.139$ & $\$ 7,139$ \\
\hline & Subtotal 4.0 & $\$ 35,694$ & $\$ 35,694$ \\
\hline TOTAL & 5 Yoars Operating and Maintenanco Costs & & $\$ 178,467$ \\
\hline
\end{tabular}


- Cost to construct ISV temporary facillty is $\$ 100 / \mathrm{ft}^{2}$

- Cost to construct meiter facility is $\$ 350 / \mathrm{ft}^{2}$

- Cost to construct alpha cells in melter facility is $\$ 1000 / \mathrm{ft}^{2}$

- One year consists of 240 days with $24 \mathrm{~h} / \mathrm{d}$

- Availability of equipment is $70 \%$

- Design capacity of each equipment is $25 \%$ over anticipated capacity

- Man power costs are estimated at $\$ 60 / \mathrm{h}$

- Electricity cost is estimated at $3.5 \phi / \mathrm{kWh}$

- Construction management cost is $17 \%$ of the total estimated direct and indirect costs

- Indirect costs are $26.5 \%$ of the estimated equipment cost

- Maintenance cost is $6 \%$ of the total estimated cost (see Reference 10)

- Operating costs are calculated for five years for ISV, and five years for melter

- ISV operations personnel required (a total of 22 ful1-time personnel per shift):
- 16 ISV operators
- 2 health physicists
- 1 supervisor
- 1 safety engineer
- 2 maintenance personnel 
- Melter operations personnel required (a total of 11 full-time personnel per shift):

- 1 person opening containers and running the melter

- 1 person packaging and moving containers

- 1 assay operator

- 1 off-gas treatment system operator

- 2 health physicists

- 1 supervisor

- 1 safety engineer

- 1 shipping and receiving coordinator

- 2 maintenance personne1

- A contingency of $25 \%$ has been app 1 ied to the total estimated cost under each category of fixed cost (e.g., research and development and demonstration and production costs).

\subsubsection{System Evaluation Results}

This section addresses the system as a whole and provides a macroscopic perspective on the overall system, including the ability to integrate the various unit operations into a smooth, we11-functioning system.

\subsubsection{Identification of Major System Considerations. ISV has been} under development since 1980 as a promising technology for remediating hazardous and radioactive waste. Although ISV has yet to be used for full-scale remediation, it has been selected as the preferred process at 11 superfund sites. A substantial amount of research and development has been invested in the process and it is now commerctally available. Demonstrations of up to 1000 tons of vitrified material have been performed. The process has been scaled up to provide adequate throughput rates to meet the remediation criteria of complete processing within 10 years.

Joule heated melters have been used by the glass making industry for over 30 years and are a well-established, commercially available technology. 
A commercial factitty would need to be adapted with the appropriate radiological control requirements for use with plutonfum- contaminated vitrifted waste, and a moderate hazard facility would need to be constructed, but the process parameters are we1l-established.

In a single process, ISV destroys and/or permanently immobilizes both organic and inorganic hazardous and radioactive contaminants, producting a leach-resistant, high integrity final waste form. A key advantage of this process is that it is performed in place, without removing or disturbing the raw waste. This significantly reduces both personnel exposure and factlity/ equipment costs. The process is relatively energy efficient, because the electrical energy is converted directly to heat in the vitrifying material. Also, the process requires relatively ifttle off-gas treatment compared to processes that use combustion gases to heat the material. The off-gas treatment process is well-established and commercially avatlable.

ISV achleves substantial volume reduction (from 20 to $60 \%$, depending on the waste material) because there are no additives, and the final waste form is relatively dense and free of volds. Substantial amounts of back-fill material would be requtred to retain the current ground level. Also, some waste materials could present processing problems. For example, large metal objects could cause a short between the electrodes, and compressed gas cylinders and barrels of organic liquids could overwhelm the off-gas treatment system.

Removing the vitrified waste would be safer and much less complicated than removing untreated waste. However, care will need to be taken to control plutonium-contaminated dust while fracturing and excavating the monolith.

Cost estimates for ISV are reasonably well defined because of the amount of research and development that has already taken place. Although the process is expensive when compared to the do-nothing option, it produces a high quality waste form and aids retrieval of the waste. The melter and its associated moderate hazard facility, though processing only a fraction of the total waste, contributes significantly to the overall cost of remediation.

IV -114 
4.2.6.2 Performance Measurables Rating. Table 1V-4-4 provides a qualttative perspective of the performance of the individual unit operations within this system relative to each other. Definttions of the measurables may be found in the system Design Study SEMP. A scale of one to ten is used to indicate the degree of success in meeting the measurable. A score of ten is defined as most successful, and a score of one is least successful.

Table IV-4-4. Rating performance measurables for the In situ Vitrification and Retrieval Processing System (2-EB-3)

\begin{tabular}{|c|c|c|c|c|c|}
\hline Measurable & $\begin{array}{c}\text { In situ } \\
\text { vitriftcation }\end{array}$ & $\begin{array}{l}\text { Off.igas } \\
\text { Treatment }\end{array}$ & $\begin{array}{c}\text { Fracture } \\
\text { and Retrteval }\end{array}$ & $\begin{array}{l}\text { Joule } \\
\text { Melter }\end{array}$ & System \\
\hline $\begin{array}{l}\text { Timeliness } \\
\text { Availability } \\
\text { Completeness } \\
\text { Risk } \\
\text { Flexibility } \\
\text { Cost } \\
\text { Safety } \\
\text { Waste reduction } \\
\text { Complexity } \\
\end{array}$ & $\begin{array}{r}8 \\
7 \\
9 \\
7 \\
8 \\
8 \\
9 \\
10 \\
10 \\
\end{array}$ & $\begin{array}{r}10 \\
10 \\
9 \\
9 \\
9 \\
10 \\
9 \\
7 \\
7 \\
\end{array}$ & $\begin{array}{l}9 \\
8 \\
9 \\
8 \\
8 \\
8 \\
9 \\
8 \\
5 \\
\end{array}$ & $\begin{array}{l}8 \\
8 \\
9 \\
8 \\
8 \\
9 \\
9 \\
8 \\
5 \\
\end{array}$ & $\begin{array}{l}8 \\
8 \\
9 \\
8 \\
8 \\
9 \\
9 \\
8 \\
8 \\
\end{array}$ \\
\hline Total & 76 & 80 & 72 & 72 & 75 \\
\hline Average & 8 & 9 & 8 & 8 & 8 \\
\hline
\end{tabular}

\subsubsection{Summary of Demonstration, Testing, and Evaluation Needs}

\subsubsection{In situ vitrification.}

- Movable electrodes

- Handling metals and large volumes of combustibles

- Site spectfic demonstration 
- Modeling (gas transport, fluid flow, heat exchange, and process chemistry)

\subsubsection{Fracture and Retrleval.}

- Dust control

\subsubsection{Joule Heated Melter.}

- Additives to ensure proper melting and product quality.

\subsection{ReCOMmendation fOR the System}

This system deserves primary consideration for further development and future implementation. It appears to be a viable system with many significant advantages. Although leaving the waste in place would be tdeal, this system appears to be the most viable system for the case where the waste must be removed.

An improvement to the system would be to eliminate the joule heated melter and its associated moderate hazard factlity and simply ISV the fines remaining from fracturing and excavating the vitrified material. Fracturing could begin as early as one year after ISV operations have begun, and the fines could be incorporated into current melting operations onstte. The fines generated after the general ISV operations are complete could be vitrified on site in small batches with the existing ISV equipment. This would eliminate the need to construct and operate a moderate hazard factlity to melt the fines with a joule heated melter. However, if such a factlity already exists, then using the existing facility would be roughily equivalent to using the ISV equipment onsite. 


\section{BIBLIOGRAPHY}

Arrenholz, D. A., 1990, In Situ Vitrification Program Treatability Investigation Program Report, EGG-WTD-9383, December.

Arrenholz, D. A., and J. L. Knight, 1991, A Brief Analysis and Description of Transuranic Wastes in the Subsurface Disposal Area of the Radioactive Waste Management Complex and INEL, EGG-WTD-9438, February.

AWC Inc., 1989, TRU Clean: A Process for Decontaminating Radioactive and Hazardous Soils.

Boehmer, A. M., et a'l., 1986, "Solldification of Hazardous and Mixed Radioactive Waste at the Idaho National Engtneering Laboratory," proceedings of the 1986 symposium on Waste Management, Tucson, Arizoria, March.

Borham, B. M., et a1., 1986, "Handling of Transuranic Waste for Volume Reduction by Incineration," Proceedings of the 1986 Symposium on Waste Management, Tucson, Arizona, March.

Bowen, M. D., et al., 1978, "A Vertical-Bed Pyrolysis System, Solid Waste and Residues Conversion by Advanced Thermal Processes, "175th Meeting of the American Chemical Society, Anaheim, California, March 13-17.

Bramlttt, E. T., 1988, "Plutonium Mining for Cleanup," Health Physics, 55, 2, August, pp. 451-453.

Cleveland, J. M., 1970, The Chemistry of Plutonium, Garden and Breech Publications: New York, pp. 48-61.

Cwynar, J. C., et a1., 1986, "Retrofit and Operation of Low-level Radwaste Solidification System," Proceedings of the 1986 Symposium on Waste Management, Tucson, Arizona, March.

Deininger, J. P., 1990, "Developments in Transuranic Element Polishing from Radioact Ive Wastewaters Using Ferrate Chemical Technology," Waste Management '90 Conference, Tucson, Arizona, March.

EPA, 1989, Guide for Conducting Treatability Studies Under CERCLA, EPA/540/2-89/058, December.

Francis, C. J., and T. M. Starr, 1990, "The ANF LLW Incinerator Design \& Start-Up," Fourth Annual Symposium on Incineration of Industrial Wastes, Knoxville, Terinessee.

Freeman, H. M., 1989, Standard Handbook of Hazardous Waste Treatment and Disposal, McGraw Hi11: New York.

Geosafe Corporation, 1989, Application and Evaluation Considerations for In situ Vitrification Technology: A Treatment Process for Destruction and/or Permanent Immobilization of Hazardous Materials, GSC 1901, April. 
Jessop, D., et a1., 1986, "Design, Installation, Testing and Start-up of a Material Handiing System at the West Valley Demonstration Project," Proceedings of the 1986 symposium on Waste Management, Tucson, Arizona, March.

Koegler, S, S., R. K. Farnsworth, R. K. Nakaoka, and S. 0. Bates, 1989, Vitrification Technologies for Weldon Spring Raffinate Sludges and Contaminated Soils Phase 2 Report: Screening of Alternatives, PNL-7125, November.

Nielson, R. K., et al., 1989, "Low Temperature Thermal Treatment of Volat lle Organic Compounds," 1989 Incineration Conference, Knoxville, Tennessee, May.

Palmer, C. A., 1989, "X-TRAX Y-12 Sludge Detoxification Demonstration," 1989 Incineration Conference for Chemical Waste Management, Knoxville, Tennessee, May.

Perry, R. H., and C. H. Chilton (eds.), 1973, Perry's Chemical Engineer's Handbook, Fifth Edition, Table 25-50.

Peters, M. S., and K. Timmerhaus, 1990, Plant Design and Economics for Chemical'Engineers, 4th edition, New York: McGraw-Hill.

Stewart, J.A., and D. L. Charlesworth, 1986, "Design and Operation of a Remotely Operated Plutonium Waste Size Reduction and Material Handing Process," Waste Management-186, Proceedings of the Symposium on Waste Management at Tucson, Arizona, March 2-6.

Theodore, L., and T. Reynolds, 1987, Introduction to Hazardous Waste Incineration, Somerset, New Jersey: John Wiley and Sons, Inc.

Wheelwright, E. J., L. A. Bray, and J. L. Ryan, 1987, Development of the CEPOD Process for Dissolving Plutonium Oxide and Leaching Plutonium from Scrap or Wastes, PN-6483. 

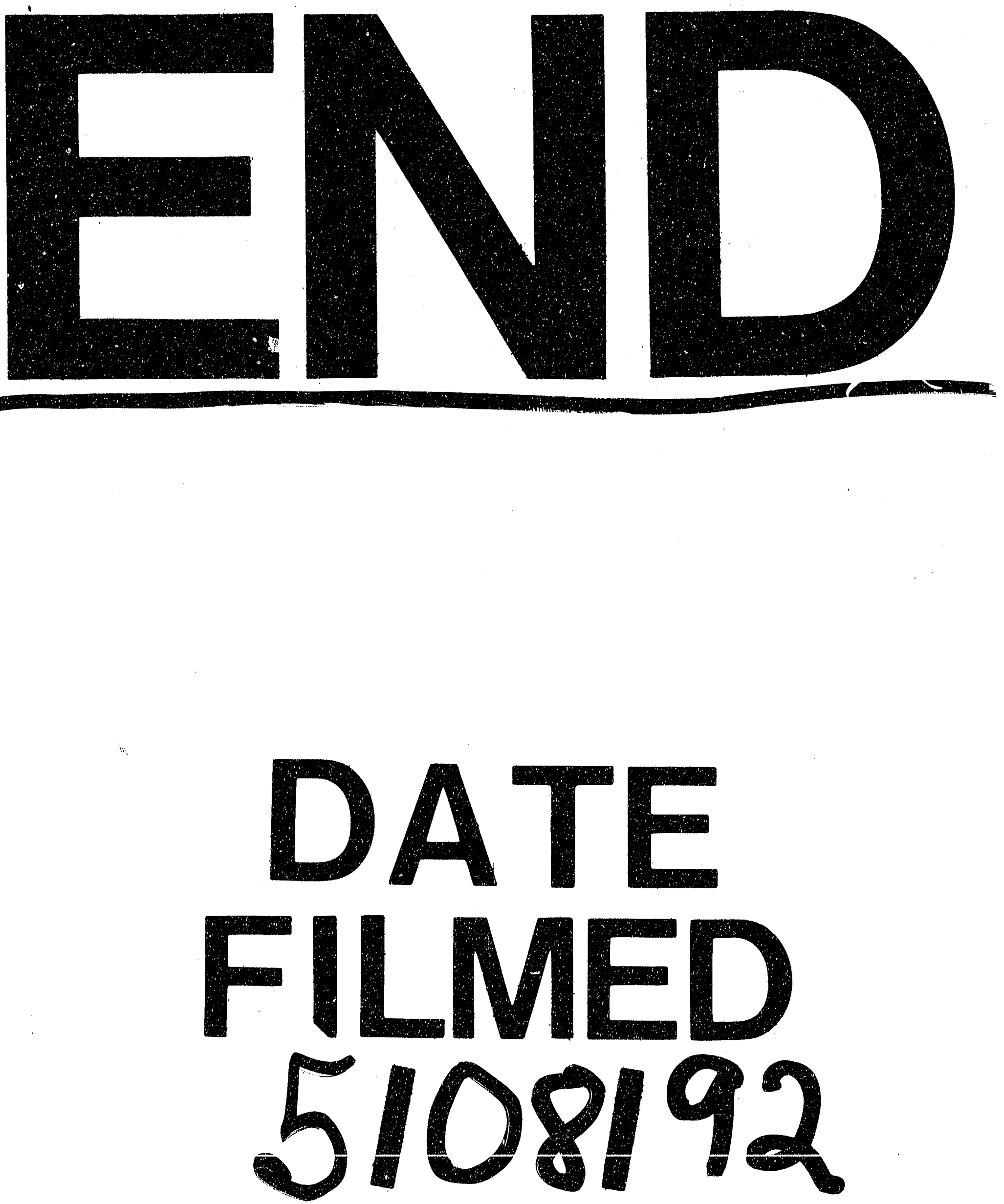


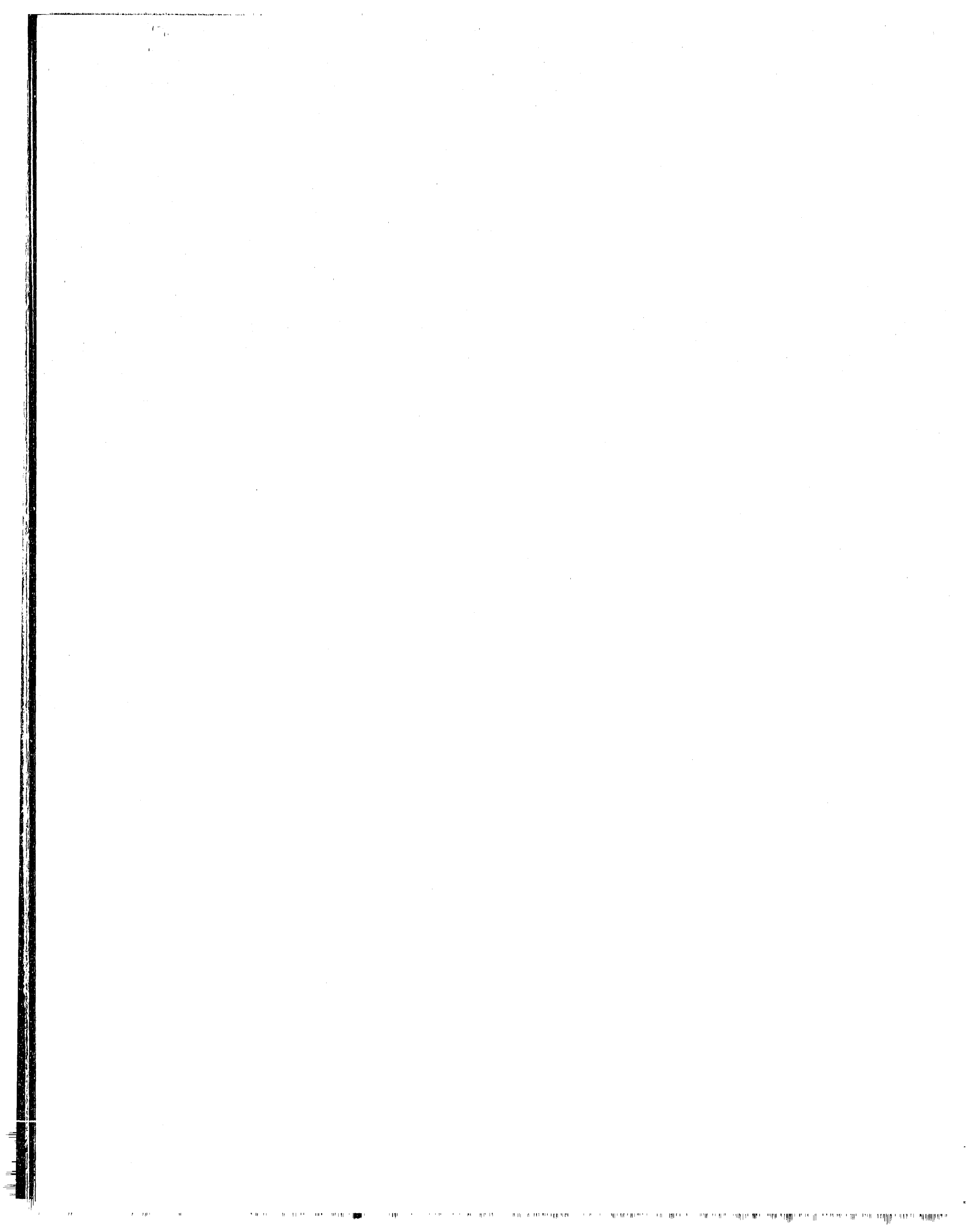

